\title{
Germ Cell Development and Migration
}

\author{
Dissertation
}

\author{
Submitted to the \\ Georg August University Göttingen, Faculty of Biology \\ For the Degree of \\ Doctor rerum naturalium \\ (Dr. rer. nat.) \\ by \\ Jürg Stebler
}

Born on the 10.02.1977 in Zurich

Göttingen 2005 
In thankful honor to my parents

Heidi and Alois Stebler 


\section{Table of Contents}

TABLE OF CONTENTS

III

ABBREVIATIONS

VI

1. INTRODUCTION

1.1 Biology of the DeVELOPMENT

1.2 Germ CelLS

1.3 Germ Cell Specification and Migration in Mouse

1.4 Germ Cell Specification and Migration In Chick

1.5 Germ Cell Specification and Migration In Zebrafish

1.6 IDENTIFICATION OF Genes ExPRESSEd IN PGCS OR Function In GeRM CeLL MigRATION

1.7 AIM OF THIS THESIS

2. RESULTS

\subsection{The Role of the Chemokine SDF-1 in Avian And Murine Germ Cell Migration} 13

2.1.1 IDENTIFICATION OF CHICKEN SDF-1

2.1.2 CHICK SDF-1 IS EXPRESSED IN POSITIONS WHERE PGCS ARE FOUND DURING THE LAST STAGES OF THEIR MIGRATION

2.1.3 PGCS CAN BE ATTRACTED TOWARDS A SOURCE OF SDF- $1 \alpha$

2.1.4 MOUSE PGCS TRANSMIGRATE THROUGH THE HINDGUT EPITHELIA EXCLUSIVELY IN THE REGION OF SDF-1 EXPRESSION

2.2 DEAD END IS ReQuired fOR Primordial Germ Cell Migration and SuRvival 24

2.2.1 DEAD END IS A NOVEL PUTATIVE RNA-BINDING PROTEIN, WHICH IS LOCALIZED TO PERINUCLEAR GERM GRANULES

2.2.2 DEAD END OVEREXPRESSION IN PGCS AND SOMATIC TISSUE DOES NOT ALTER

GERM CELL SPECIFICATION AND NUMBER

2.2.3 DEAD END IS REQUIRED FOR PGC MIGRATION

2.2.4 ZEBRAFISH DEAD END IS REQUIRED FOR PGC SURVIVAL

2.2.5 DEAD END EXPRESSION IS CONSERVED IN OTHER VERTEBRATE SPECIES

2.2.6 IDENTIFICATION OF DEAD END INTERACTION PARTNERS 
3.1 Germ Cell Migration

3.2 The Role of the Chemokine SDF-1 in Avian Germ Cell Migration 36

3.3 The Role OF the ChemoKine SDF-1 in Murine Germ Cell Migration 37

3.4 CONSERVATION OF THE MECHANISM OF PGC GUIDANCE

3.5 BASIS AND RELEVANCE TO SCREEN FOR GERM PLASM COMPONENTS: THE IDENTIFICATION OF DEAD END

3.6 DEAD END, A Germ Plasm Component is Associated With Perinuclear GRANULES

3.7 Dead end and Germ Cell Specification 40

3.8 DEAD END IS IMPORTANT FOR PGC MOTILITY

3.9 DEAD END IS ESSENTIAL FOR PGC SURVIVAL 42

3.10 Dead end, PGCs AND Zebrafish SeX Determination 43

4. SUMMARY \& CONCLUSIONS

5. MATERIAL AND METHODS

5.1 BACTERIA

5.2 ChEMICALS

5.3 KITS

46

5.4 Primary and Secondary antibodies 47

5.5 DNA CONSTRUCTS USED IN THIS WORK $\quad 47$

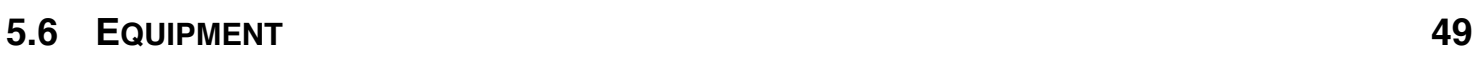

5.7 Programs, Database, 49

5.8 MOLECULAR BIOLOGY $\quad 50$

5.8.1 PLASMID DNA ISOLATION FROM E. COLI

5.8.2 TOTAL RNA ISOLATION FROM EUKARYOTIC CELLS OR EMBRYOS

5.8.3 DNA AND RNA ELECTROPHORESIS AND PURIFICATION FROM AGAROSE GEL 51

5.8.4 DNA DIGESTION WITH RESTRICTION ENZYMES

5.8.5 DEPHOSPHORYLATING AND BLUNTING OF DNA FRAGMENT

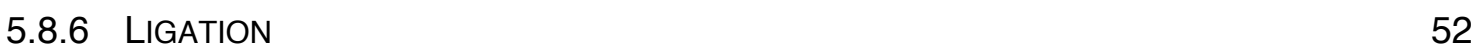

5.8.7 STANDARD PCRS $\quad 52$

5.8.8 HIGH FIDELITY PCRS

5.8.9 AMPLIFICATION OF 5' AND 3' END OF CDNAS 52

5.8.10 STANDARD REVERSE TRANSCRIPTION

5.8.11 PGC SPECIFIC FULL LENGTH CDNA LIBRARY SYNTHESIS

5.8.12 YEAST-TWO-HYBRID SCREEN

5.8.13 Preparation OF ElECtROCOMPETENT E. COLI CELLS AND TRANSFORMATION by ELECTROPORATION

$\begin{array}{lll}5.9 & \text { BIOCHEMISTRY } & 56\end{array}$

5.9.1 IMMUNOPRECIPITATION (IP) 56

5.9.2 PROTEIN GEL ELECTROPHORESIS 58

5.9.3 COOMASSIE BLUE StAINING 59 
5.9.4 SilVER STAINING FOR MASS SPECTROMETRY 59

5.9.5 WESTERN BLOTTING 60

5.10 Cell Biology

5.10.1 Cell Culture Medium $\quad 62$

5.10.2 CELL REVIVAL $\quad 62$

5.10.3 CELL PASSAGE AND FREEZE

5.10.4 CELL TRANSFECTIONS WITH PLASMIDS 63

$\begin{array}{ll}5.11 & \text { ZEBRAFISH }\end{array}$

$\begin{array}{lll}5.11 .1 & \text { FISH BREEDING AND INCUBATION } & 64\end{array}$

5.11.2 MORPHOLINOS $\quad 65$

5.11.3 LINEARIZATION OF PLASMID FOR IN VITRO TRANSCRIPTION 65

5.11.4 MRNA SYNTHESIS FOR INJECTION

5.11.5 INJECTION OF ZEBRAFISH EMBRYOS 66

5.11.6 IMMUNOSTAINING OF ZEBRAFISH EMBRYOS 66

5.11.7 DIG- AND FLUO- LABELED RNA PROBE SYNTHESIS 67

5.11.8 ZEBRAFISH ONE- AND TWO-COLOUR WHOLE MOUNT IN SITU HYBRIDIZATION 67

5.11.9 MICROSCOPY AND TIME-LAPSE ANALYSIS 73

$\begin{array}{lll}5.12 & \text { CHICKEN } & 73\end{array}$

5.12.1 CULTIVATION OF CHICKEN EMBRYOS

5.12.2 EARLY CHICK (EC)-CULTURE

5.12.3 IMPLANTATION OF COS 7 CELLS INTO CHICK EMBRYOS 76

5.12.4 ELECTROPORATION

5.12.5 CHICK WHOLE-MOUNT IN SITU HYBRIDIZATION

5.12.6 Histology - Preparation OF ParafFin SECtions 80

$\begin{array}{ll}\mathbf{5 . 1 3} \text { MOUSE } & \mathbf{8 1}\end{array}$

5.13.1 MOUSE WHOLE-MOUNT IN SITU HYBRIDIZATION

5.13.2 MOUSE ORGan CULTURE AND TIME LAPSE

6. REFERENCES $\quad 86$

\begin{tabular}{ll} 
7. & ACKNOWLEDGMENTS \\
\hline
\end{tabular}

8. APPENDIX $\quad 98$

$\begin{array}{lll}8.1 & \text { AFFIDAVIT } & 98\end{array}$

8.2 LIST OF PUBLICATIONS 99

$\begin{array}{lll}8.3 & \text { CuRriculum VitaE } & 100\end{array}$ 


\section{Abbreviations}

Amp

Dig

dnd

dpf

E.coli

EDTA

EST

FCS

Fluo

$\mathrm{g}$

GFP

glo

$\mathrm{HH}$

$\mathrm{Hpf}$

HRP

IB

IgG

IP

kDA

min

$\mathrm{ml}$

$\mathrm{MO}$

nos 1

o/e

ORF

PAGE

PBS

PCR

PGC

PMSF

rpm

RT

SDF-1

SDS

sec

U

UTR

V

V

WB
Ampicillin

Digoxigenin

dead end

day post fertilization

Escherichia coli

Ethylene diamine tetra actetic acid

Expressed sequence tag

Fetal calf serum

Fluorecein

gravity

Green fluorescence protein

globin

staging according to Hamburger and

Hamilton (Hamburger and Hamilton, 1951)

hours post fertilization

horse radish peroxidase

Immunoblot

Immunoglobulin G

Immunoprecipitation

kilo Dalton

minutes

milliliter

Morpholino antisense oligonucleotide

nanos-1

overexpression

open reading frame

Poly acrylamide gel electrophoresis

Phosphate buffered saline

Polymerase chain reaction

primordial germ cell

Phenylmethylsulfonyl fluoride

rotations per minute

Room temperature

Stromal cell-derived factor 1

Sodium dodecyl sulfate

seconds

units

Untranslated region

Volt

volume

Western blot 


\section{Introduction}

\subsection{Biology of the Development}

During the course of development, a single cell, the zygote, will after numerous divisions ultimately give rise to a complex organism consisting of various different cell types. These cells, first regionally specified by asymmetric distribution of cytoplasmic determinants, by inductive signals and/or cell autonomous processes organize into functionally diverse tissues and organs of the body. A central aim in developmental biology is to understand the molecular processes that enable a single cell (the zygote) to generate multicellular and highly organized tissues, organs and organisms. The numerous aspects of this discipline include the formation of an organism as well as the investigation of aberrant cell behavior that can cause diseases. A multitude of questions have to be solved to understand these complex processes, such as: How are the different cells specified to give rise to a certain cell type? How cells communicate with neighboring cells to organize complex structures e.g. an embryo or a partially formed organ? What are the reasons that some cells divide more than others? What are the molecular mechanisms that allows only a part of the genome to be used and how is it differentially regulated in the thousands of different cell types of higher organisms?

The multidisciplinary field of developmental biology, combining among other fields genetics, anatomy, embryology, molecular- and cell biology, contributed to the growing understanding of the mechanism responsible for the formation of a multicellular organism. However, the present understanding is in most processes still basic and many questions remain unanswered. 


\subsection{Germ Cells}

Continuation of the germ cell lineage guarantees transmission of genetic information from one generation to the next by sexual reproduction, the fusion of gametes to create a zygote. All sexually reproducing organisms arise from gametes (sperm and egg), which develop from primordial germ cells (PGCs), a small population of cells that set aside from other cell lineages early in embryonic life in most animal species. Differentiation of the germ cells into gametes occurs in the gonad, an organ comprised of the germ cells and somatic tissue, which supports and directs proper gamete differentiation. During the process of differentiation, which includes meiosis and DNA recombination, germ cells generate unique gametes and consequently unique individuals (Niewkoop and Sutasurya, 1979; Starz-Gaiano and Lehmann, 2001; Wylie, 1999; Zhao and Garbers, 2002).

Primordial germ cell specification marks the initiation of the life cycle of the germ cell lineage. The basic mechanism of PGCs being set aside as a distinct cell population early during embryogenesis is common throughout the phylogeny from invertebrates to mammals (Houston and King, 2000a; Ikenishi, 1998; McLaren, 1999; Seydoux and Schedl, 2001; Starz-Gaiano and Lehmann, 2001; Wylie, 1999). However, the molecular mechanisms responsible for PGC specification differ in different organisms. In many species, including Xenopus, zebrafish, Drosophila and C.elegans, germ cells are specified by the inheritance of maternal factors deposited in the egg during oogenesis that contain germ cell determinants, the germ plasm (Houston and King, 2000a; Houston and King, 2000b; Lehmann and Nusslein-Volhard, 1991; Seydoux and Schedl, 2001; Yoon et al., 1997). In contrast to these organisms, PGCs in mammals and urodeles segregate from the somatic cell lineage by inductive signals from tissues at an early gastrulation stage (Lawson et al., 1999; Ying et al., 2001).

In many species the germ cells are specified in regions distinct from the site where the gonad will form. Therefore, PGCs have to migrate from their site of specification towards the region where the gonad develops. The mechanisms allowing directed germ cell migration in Drosophila, Xenopus, zebrafish and mouse have been studied intensively over the last decades (reviewed in (Molyneaux and Wylie, 2004; Raz, 2004; Santos and Lehmann, 2004; Starz-Gaiano and Lehmann, 2001; Wylie, 2000). The general conclusion from these studies is that the movements of the PGCs towards the gonadal region rely on directional cues provided by the somatic environment. The precise molecular mechanisms responsible for this feature of the germ cells were and still are, however, largely not known. 


\subsection{Germ Cell Specification and Migration in Mouse}

In early mammalian embryogenesis, the newly formed zygote divides three times to give rise to eight cells with each equal totipotency. At the 16-cell stage, cellular differentiation occurs, whereas the cells at the center remain pluripotent and give rise to the inner cell mass (ICM), while cells at the periphery become the first differentiated embryonic cell types, called the trophoectoderm or trophoblast (Beddington and Robertson, 1999). At the 32-cell stage, the trophoectoderm forms the wall of a sphere and the ICM is enclosed in one hemisphere, while a second inner cavity, the blastocoel, is formed. Subsequently, cells on the surface of the ICM, facing the blastocoel, differentiate into primitive endoderm that forms visceral and parietal endoderm, while the rest of the ICM remains pluripotent and becomes primitive ectoderm or epiblast. Eventually, epiblast cells of the early gastrula give rise to primordial germ cell precursor at a stage of E5.5-E6.5 (de Sousa Lopes et al., 2004; Lawson et al., 1999; Tam and Zhou, 1996; Ying et al., 2001) (Figure 1-1).

Transplantation experiments of different tissues of the mouse embryo led to the conclusion that signals produced by the extraembryonic ectoderm induce epiblast cells to become PGC precursors, which then eventually migrate toward the primitive streak and segregate into PGC and allantois lineages (Ginsburg et al., 1990; Starz-Gaiano and Lehmann, 2001; Tam and Zhou, 1996),

The signal transduction cascade activated by bone morphogenetic protein 4 (BMP4), the type I BMP receptor ALK2 and the downstream Smad1 and Smad5 were demonstrated to be necessary for the generation of PGCs (Chang and Matzuk, 2001; de Sousa Lopes et al., 2004; Hayashi et al., 2002; Lawson et al., 1999; Tremblay et al., 2001). In addition, the BMP family members BMP8b and BMP2 have been shown to play a role in the formation of PGCs as well (Ying et al., 2000; Ying et al., 2001; Ying and Zhao, 2001). Recent findings showed that the zinc-finger containing DNAbinding transcriptional repressor Blimp1 is essential for specification of PGCs (Vincent et al., 2005), whereas the gene targets important for the germ cell specification process are currently unknown.

Following primordial germ cell precursor (pPGCs) specification at E5.5-E6.5, the cells migrate toward the primitive streak where they can be identified by alkaline phosphates and stella expression at the root of the allantois around E7.5 (Ginsburg et al., 1990; Saitou et al., 2002; Tanaka and Matsui, 2002). Germ cells incorporate into the hindgut pocket of the developing hindgut epithelium and move in random directions along the anterior-posterior axis in the closed hindgut (Anderson et al., 2000). At E9.0, 
all PGCs

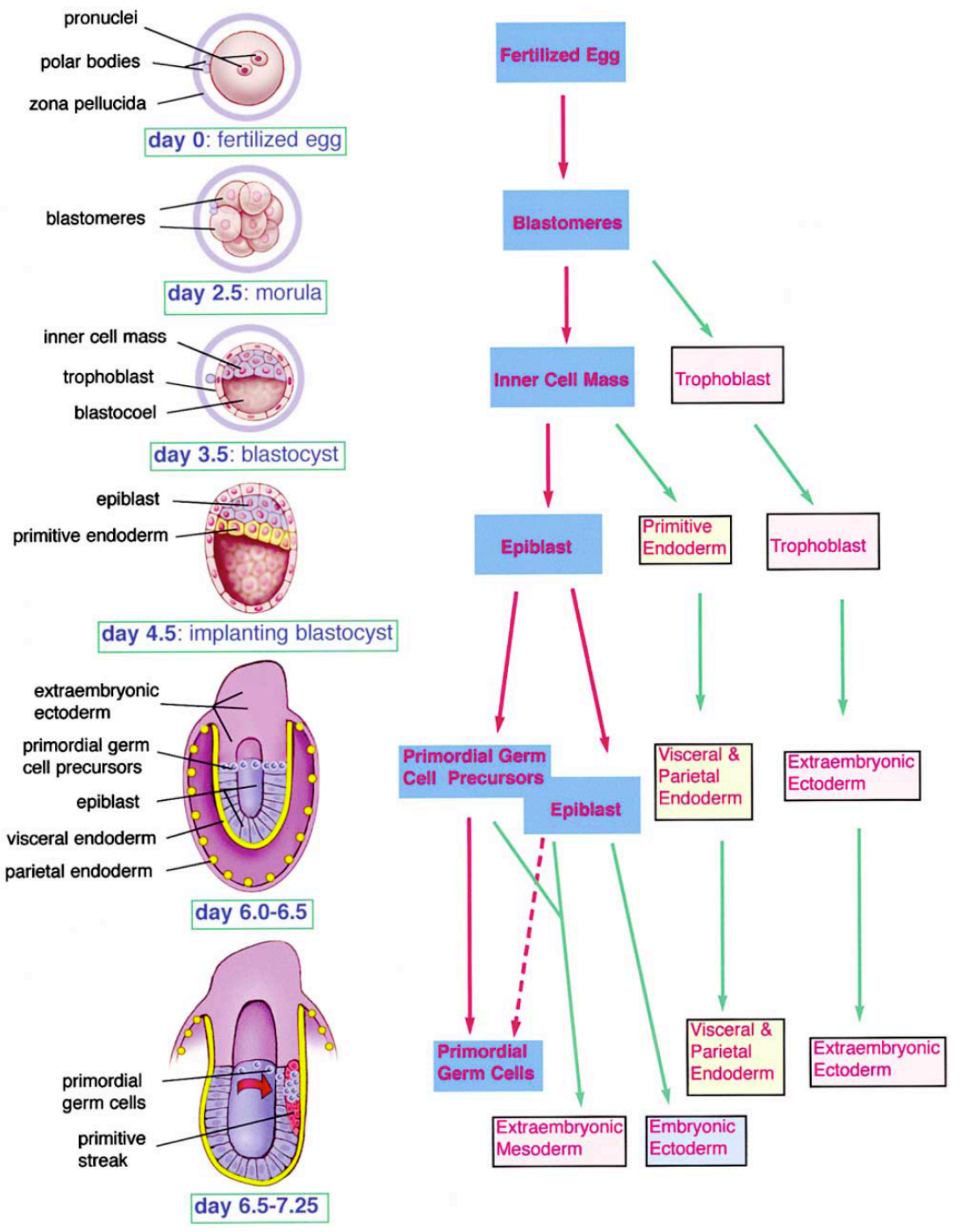

Figure 1-1: From fertilized egg to primordial germ cell specification. The development of a mouse embryo from fertilization (embryonic day 0) to the time of PGC specification at day 7.25 is shown on the left. PGC precursors in the proximal epiblast and PGCs in the primitive streak area are depicted as blue circles with darker smaller circles as nuclei. The appearance of different cell types during early development is shown on the right as boxes. Arrows are used to show differentiation. Cells considered totipotent or pluripotent are boxed in blue. These include the fertilized egg, blastomeres, cells in the inner cell mass (ICM), epiblast, PGC precursors, and PGCs. Red arrows are used to indicate the path from totipotency and pluripotency to PGCs. In addition to the PGC precursors, some epiblast cells have the potential to form PGCs in vitro (shown by a dashed red arrow). Green arrows are used to indicate differentiation of cells that do not have pluripotent character. (Adapted from (Zhao and Garbers, 2002)) 
are found in the hindgut and are motile. About 12 hours later, PGCs start to actively transmigrate the hindgut epithelium and migrate via the dorsal mesentery towards the genital ridges between E10.0 and E11.5 (Molyneaux et al., 2001) (Figure 1-2).
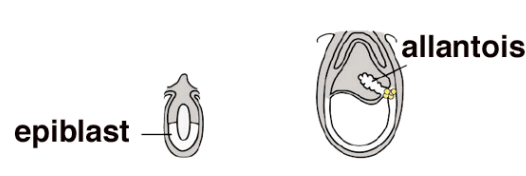

\section{E 6.0 E 7.5}
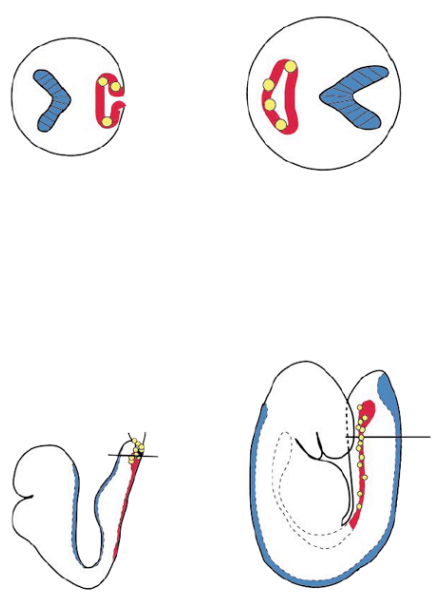

E 8.0

E 9.0
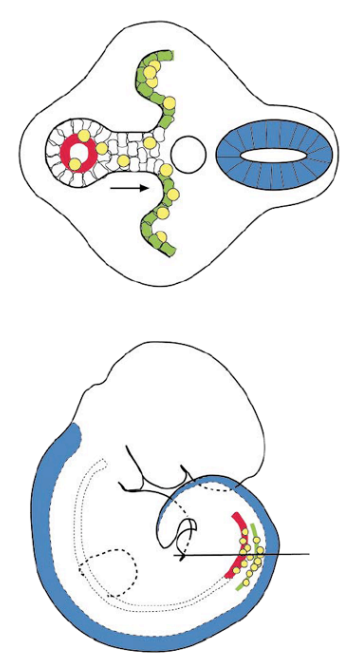

E 10.5

Figure 1-2: Germ cell migration in the mouse embryo. E6: The primordial germ cell precursors are formed. E7.5: The germ cells (yellow) are specified. E8: Germ cells occupy the developing hindgut epithelium (hindgut pocket, red) and are highly motile. Neural plate in blue. E9: Embryo has turned, PGCs are still in the hindgut. Following 24 hours (E9.0-10.0), PGCs start to leave the hindgut epithelium and migrate via the dorsal mesentery towards the genital ridges (green). E10.5: Germ cells migrate toward the gonad and until E11.5. (Adapted from (Molyneaux et al., 2001; Starz-Gaiano and Lehmann, 2001))

Numerous factors have been implicated in controlling mouse PGC migration and these include extracellular matrix components such as integrins and signaling molecules such as the receptor tyrosine kinase steel and its ligand ((Anderson et al., 1999; Bernex et al., 1996; Garcia-Castro et al., 1997; Gomperts et al., 1994; Pellas et al., 1991) and reviewed by (Molyneaux and Wylie, 2004; Santos and Lehmann, 2004; Starz-Gaiano and Lehmann, 2001; Wylie, 2000)). Nevertheless, the actual cues, guiding mouse primordial germ cells into the hindgut pocket or from the hindgut via the dorsal mesentery towards the genital ridges were not known at the time the work described in this thesis was initiated. 


\subsection{Germ Cell Specification and Migration in Chick}

In contrast to other model organisms such as mouse, Xenopus, zebrafish, Drosophila and C.elegans, germ cell specification and migration in the chick embryo were less intensively studied and therefore very little were known regarding the molecular mechanisms governing these processes.

In the chick embryo, germ cells are specified in the epiblast in the central zone of the area pellucida (Karagenc et al., 1996; Petitte et al., 1997; Tsunekawa et al., 2000), whereas the factors important for this process are unknown. From this position the cells, expressing the chicken homologue of vasa (Tsunekawa et al., 2000), are translocated by morphogenetic movements to the anterior extraembryonic region called the germinal crescent where they incorporate into the forming extraembryonic vascular network (stage 8-10 according to Hamburger and Hamilton ( $\mathrm{HH} \mathrm{8-10),}$ (Hamburger and Hamilton, 1951)) and start to circulate within the blood stream (stage $\mathrm{HH}$ 11) (Ginsburg and Eyal-Giladi, 1987; Tsunekawa et al., 2000). Later in development, germ cells leave the vascular system and migrate into the region where the gonad develops (HH 15-29) (reviewed by (Niewkoop and Sutasurya, 1979)).

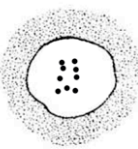

Stage $X$

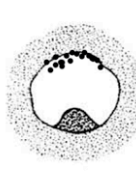

HH1

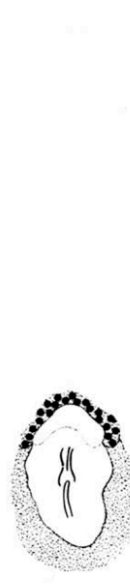

HH5

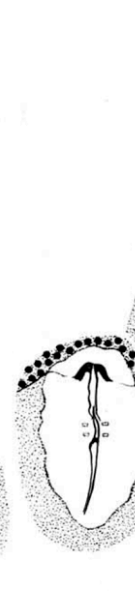

HH7

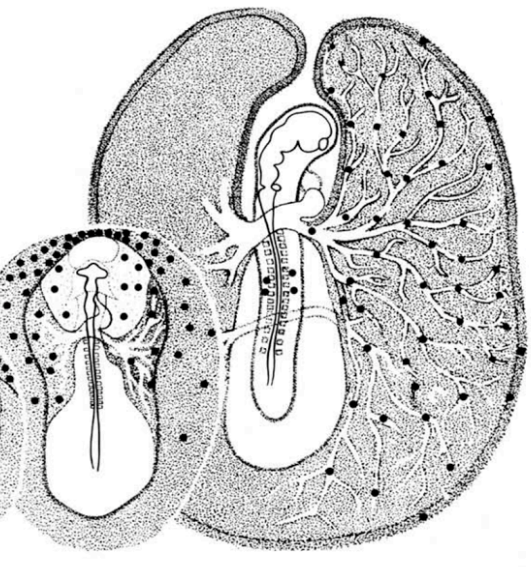

HH10

HH15

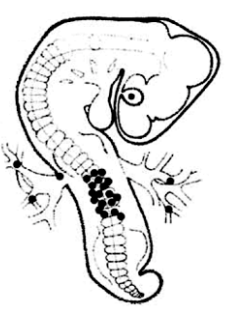

HH21

Figure 1-3: Germ cell specification and migration in the chick embryo. At stage X, PGCs are specified in the central zone of the area pellucida and translocated by morphogenetic movement to the anterior extraembryonic region, the germinal crescent. From $\mathrm{HH} 1$ to $\mathrm{HH} 10$, Germ cells proliferate and incorporate into the forming vascular system. When the heart starts to pulsate at $\mathrm{HH} 10, \mathrm{PGCs}$ are passively circulating through in the blood stream until $\mathrm{HH} 15$. From $\mathrm{HH} 15$ on, PGCs leave the vascular system and migrate actively towards the genital ridge. (Adapted from (Niewkoop and Sutasurya, 1979)). 
The migration path of PGCs in the chick is strikingly similar to the route taken by leukocytes during normal development and in response to an immune challenge as well as to the route metastatic cells follow on their way to form secondary tumors. In all of those cases, the vascular system serves as a vehicle to transport the cells to distant locations and migration through the vessel wall takes place in the vicinity of the target tissue.

Although the molecular mechanism responsible for germ cell migration including extravasation from the endothelial system was not known, the existence of a guidance cue directing the migrating cells to the developing gonad was supported by results of transplantations- and in vitro experiments (Rogulska, 1969; Rogulska et al., 1971).

\subsection{Germ Cell Specification and Migration in Zebrafish}

The zebrafish, Danio rerio, has become an important model system for studying PGC development and migration as it offers several advantages over other vertebrate and invertebrate model organisms (Kimmel, 1989). The combination of extra-uterine development, a large number of progeny, the availability of genetic mutations coupled with the optical clarity of the embryo is unique for this model organism. In addition to mutagenesis-based screens, the analysis of protein function in vivo became extremely rapid thanks to a new technology that allows knock-down of specific genes in zebrafish by injection of modified antisense oligonucleotides (Nasevicius and Ekker, 2000).

As mentioned above zebrafishgerm cells are specified by the maternal inheritance of asymmetric localized cytoplamic determinants, referred to as germ plasm. During the 1-cell stage, germ plasm components such as vasa RNA (Braat et al., 1999; Knaut et al., 2000; Yoon et al., 1997) and nanos-1 RNA (nos-1) (Koprunner et al., 2001) are uniformly distributed in the embryo, but accumulate at the distal parts of the cleavage furrows after the first and second cell division (Figure 1-4, 2-/4-cell arrow). Following additional cell divisions, the zebrafish germ plasm is incorporated into four blastomeres. The number of blastomeres harbouring germ plasm remain constant until blastula stages as a result of asymmetric cell divisions where germ plasm material is distributed only to one daughter cell (Knaut et al., 2000). At the late blastula stage (4 hpf, $4 \mathrm{k}$ cell, late sphere stage) PGC specification occurs, and as a result in subsequent divisions the germ plasm is symmetrically distributed to both daughter cells resulting in an increase in the PGC population (Knaut et al., 2000). 

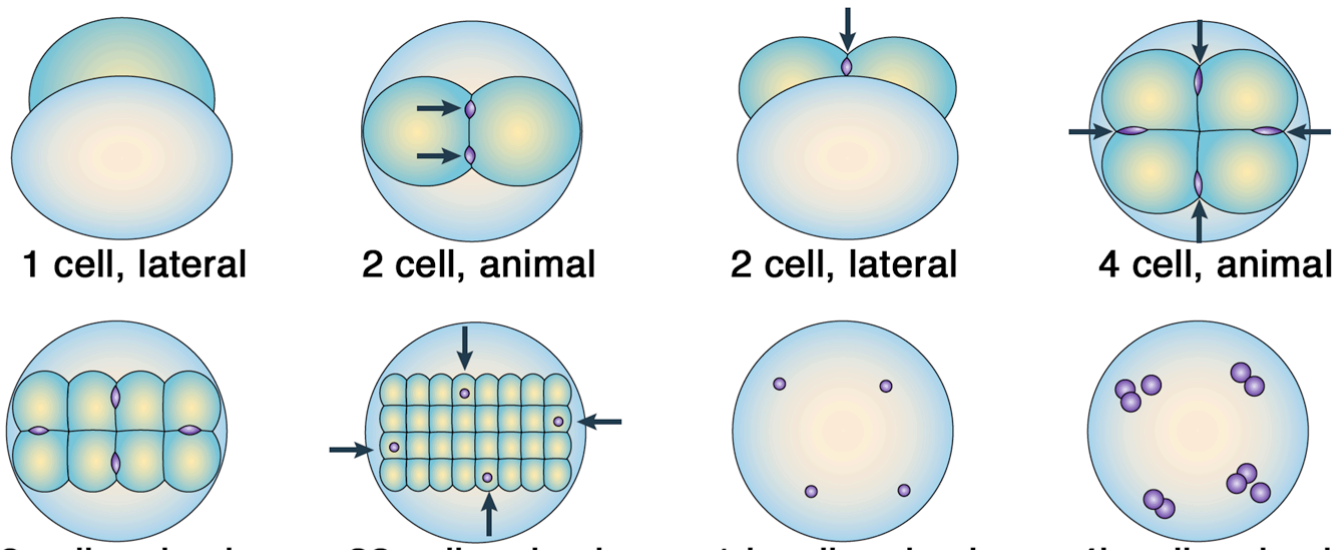

8 cell, animal

32 cell, animal
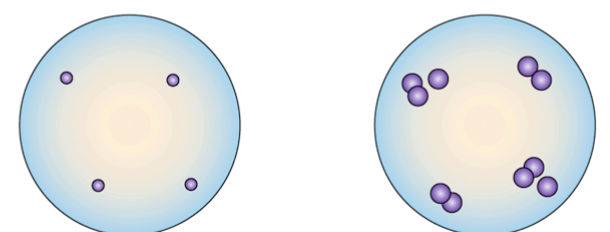

$1 \mathrm{k}$ cell, animal

4k cell, animal

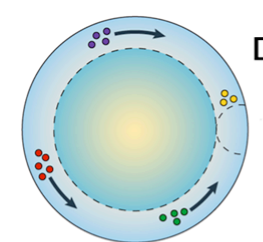

Dome, animal

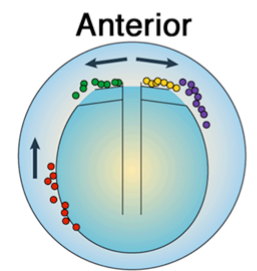

2 somites, dorsal

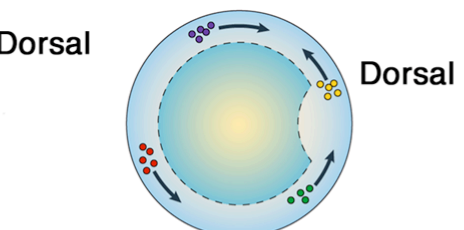

$60 \%$ epiboly, animal

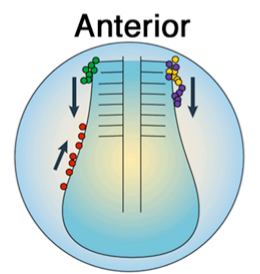

8 somites, dorsal

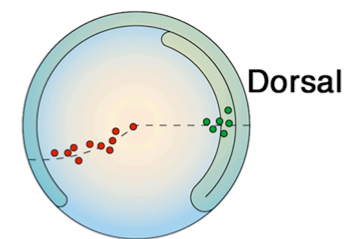

$80 \%$ epiboly, lateral

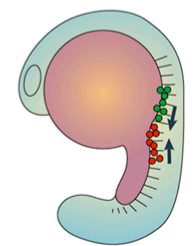

19 somites, lateral

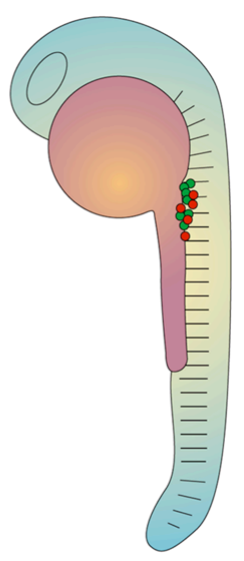

$24 \mathrm{hpf}$, lateral

Figure 1-4: Germ cell specification and the six steps of early PGC migration in zebrafish. Schematic drawings of embryos from 1 cell stage to $24 \mathrm{hpf}$ showing the process of PGC specification and positions/movements of the four PGC clusters.

( 1 cell) Maternal inheritaded and asymmetric localized cytoplamic determinants, referred to as germ plasm, is uniform distributed in the cell.

(2/4 cell) At the end of the first two cell divisions, germ plasm components accumulate at the distal parts of the cleavage furrows.

(32 cell $-1 \mathrm{k}$ cell) During early cleavage stages, the zebrafish germ plasm is incorporated into four blastomeres, which asymmetrically divide and inherite the germ plasm to only one daughter cell .

( 4 k cell) Germ cells are specified and divide symmetrically.

(Dome) At dome stage, four clusters of PGCs are found close to the blastoderm margin in a symmetrical 'square' shape. All possible orientations of the square relative to the dorsal side of the embryo can be observed. Here, an intermediate arrangement is shown with one cluster close to, but not directly at the dorsal side. Before gastrulation, lateral and ventral clusters move towards the dorsal, with ventral clusters migrating more slowly (step I, convergence 
towards the dorsal). This movement is shared with somatic cells and can be attributed to early compaction before gastrulation and dorsal convergence of hypoblast cells during gastrulation.

(60\% epiboly) Clusters located very close to the dorsal migrate away from the dorsal midline and are therefore rarely found on the notochord from the $60 \%$ epiboly stage on (step II, exclusion from the dorsal midline).

(80\% epiboly) Dorsally located PGCs align along the border between the head and trunk paraxial mesoderm depicted by a dashed line (step IIIa, alignment along the anterior border of the trunk mesoderm). Ventrally located clusters align at the lateral border of the mesoderm (step IIlb, alignment along the lateral border of the mesoderm).

(2 somites) At the 2-somite stage, most PGCs have arrived in two lines at the level of the first somite. These anterior located PGCs migrate towards the lateral (stepIV, formation of two lateral PGC clusters). Cells that were initially located ventrally migrate towards the anterior (step V, anterior migration of trailing PGCs). In this illustration, the positions of the PGCs are drawn relative to the adaxial cells, the somites and the lateral border of the pronephric anlage.

(8 somites) At the 8-somite stage, all anterior PGCs are found lateral to the paraxial mesoderm in a cluster extending from the 1 st to the $3^{\text {rd }}$ somite. These clusters start to move towards the posterior (step $\mathrm{VI}$, posterior positioning of the PGC clusters), while the trailing cells migrate anteriorly. Here, the PGCs are drawn relative to the expression domains of myoD in the adaxial cells and somites and pax2.1in the pronephros.

(19 somites) At the 19-somite stage, the main clusters have shifted to more posterior positions and in $60 \%$ of embryos some trailing cells are still seen.

(24 hpf) At $24 \mathrm{hpf}$, the PGC clusters are located at the anterior end of the yolk extension, which corresponds to the $8^{\text {th }}$ to $10^{\text {th }}$ somite level. In most embryos, all PGCs have reached this region, only a few trailing cells are found close to the main clusters. (Adapted from (Raz, 2003; Weidinger et al., 1999a)).

For different germ plasm components, a substantial fraction is not incorporated into the PGCs and remains detectable in somatic cells as late as up to early epiboly stages ( 5 hpf - Dome, (Braat et al., 1999; Knaut et al., 2000; Koprunner et al., 2001; Olsen et al., 1997; Wolke et al., 2002; Yoon et al., 1997)). Germ plasm components, such as vasa and nanos-1 RNA have been shown to be actively degraded in the somatic tissue in a process mediated by cis-acting elements in the RNA (Koprunner et al., 2001; Wolke et al., 2002). Similarly, RNA elements were shown to inhibit the translation of those RNAs in somatic cells (Koprunner et al., 2001).

As a result of the position where the germ cells are specified, zebrafish PGCs start their migration from positions that are random with respect to the dorso-ventral body axis. Hence, in contrast to many other organisms, where germ cells are specified on one site and therefore start to migrate from one place, PGCs in zebrafish start migrating from four different positions (Figure 1-4, Dome stage). The route, germ cell follow in the course of their migration during of the first day of development, could be divided into six distinct steps and culminates in the formation of two clusters in the region where the gonad will form (Figure 1-4, (Weidinger et al., 1999a)). 


\subsection{Identification of Genes Expressed in PGCs or Function in Germ Cell Migration}

In a large-scale screen, our lab and others have identified the chemokine receptor CXCR4b (Doitsidou et al., 2002; Knaut et al., 2003) and its ligand SDF-1a (Doitsidou et al., 2002) as key proteins essential for guided migration of primordial germ cells from their site of specification to the region of the zebrafish gonad.

SDF-1 - CXCR4 signaling has previously been shown to regulate numerous processes in development (Aiuti et al., 1997; Bleul et al., 1996a; Bleul et al., 1996b; Ma et al., 1998; Nagasawa et al., 1996; Tachibana et al., 1998; Zhu et al., 2002) and in diseases (e.g. tumors/metastasis and inflammatory processes) (Abi-Younes et al., 2000; Buckley et al., 2000; Epstein, 2004; Hernandez et al., 2003; Muller et al., 2001; Staller et al., 2003; Zeelenberg et al., 2003). In zebrafish embryos, sdf-1a was found to be expressed in positions where the PGCs were found or towards which they were migrating $(A)$.

Figure 1-5: The role of Cxcr4b and Sdf-1a in germ-cell migration. (A) In zebrafish embryos, the germ cells (blue) are found in positions where the sdf-1a RNA (red) is highly expressed. (B) Alterations in the level of Sdf-1a signaling in the primordial germ cells result in defects of germcell migration. In contrast to wild-type embryos, in which most of the germ cells are found in the region of the gonad by the end of the first day of development, inhibiting the translation of $c x c r 4 b$ or Sdf1a (not shown) in the germ cells results in migration defects.

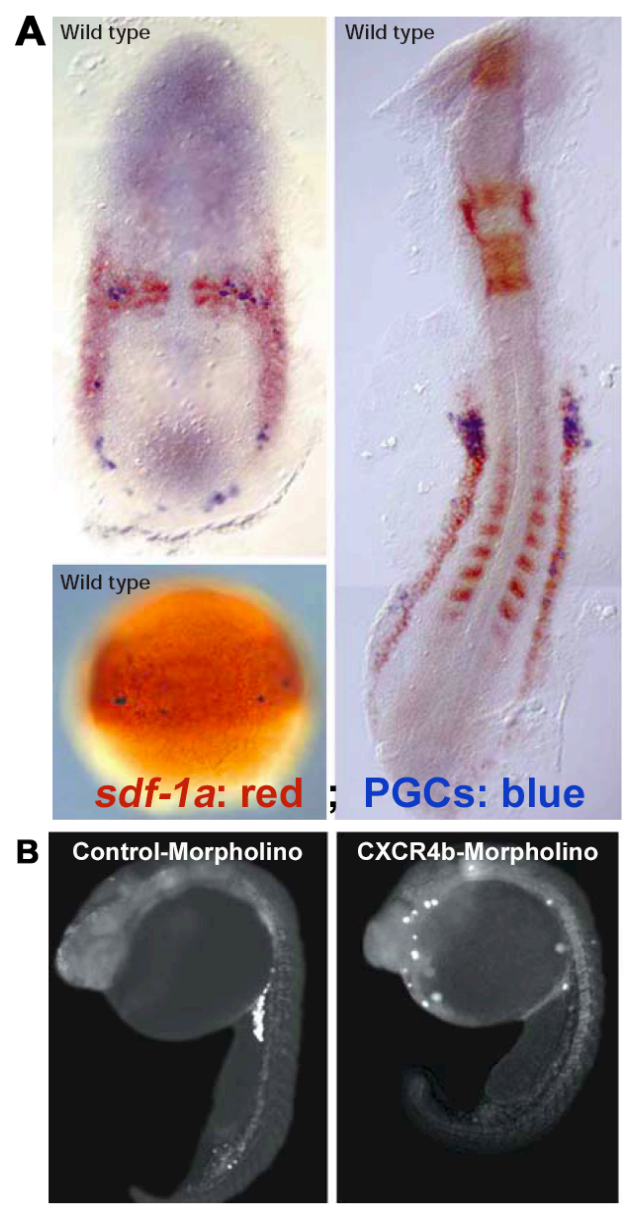


In embryos, in which the receptor or ligand was knocked down, PGCs lost their ability to migrate directionally towards the region of the gonad and were therefore found in ectopic positions within the embryo (B (Doitsidou et al., 2002). Furthermore, in embryos in which the ligand or the receptor was knocked down and an ectopic source of SDF-1a was introduced, germ cells migrated towards the new location where SDF1a was highly expressed (Doitsidou et al., 2002).

In another screen, based on whole mount in situ hybridization to identify genes expressed in zebrafish PGCs, we identified a novel gene, dead end (dnd), which is specifically expressed in germ plasm and primordial germ cells (Weidinger et al., 2003).

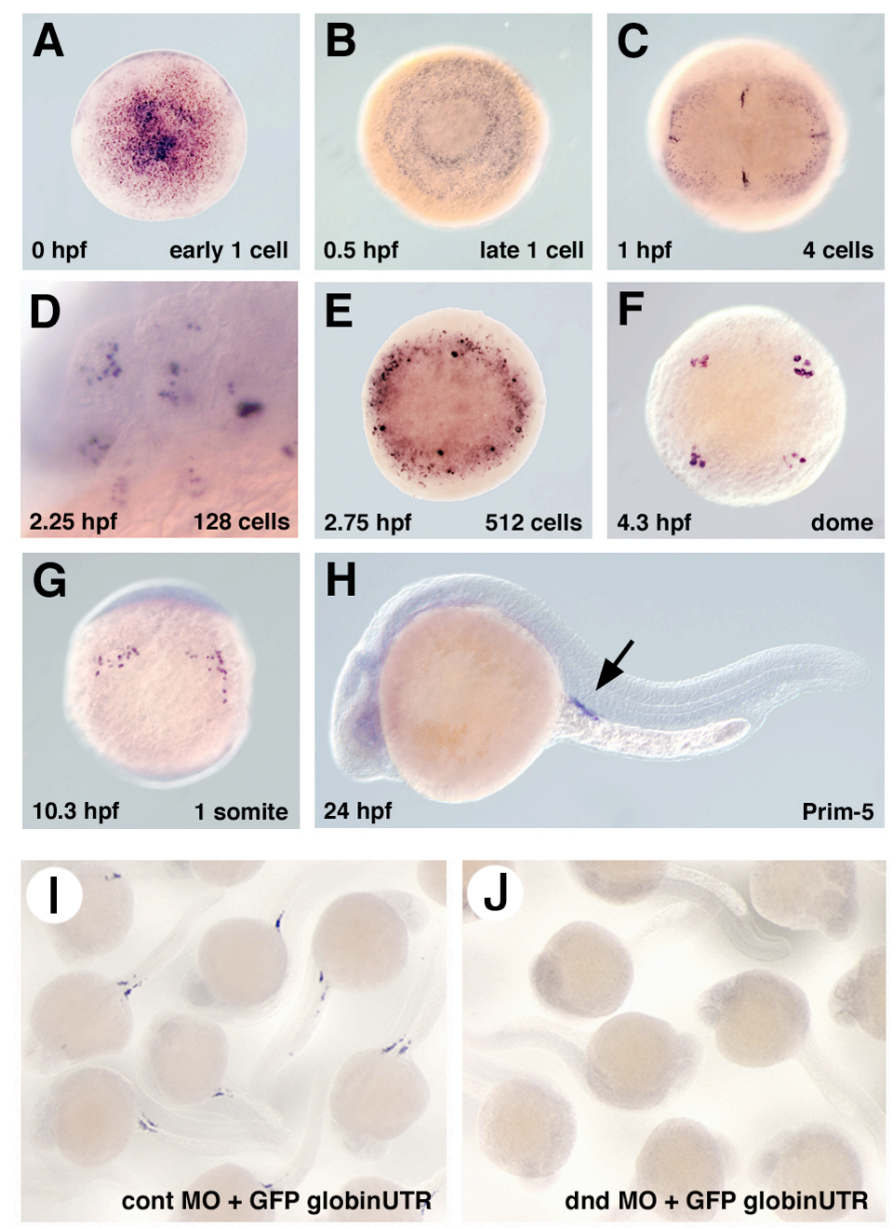

Figure 1-6: dead end expression during the first day of development and loss of PGCs in Dead end depleted zebrafish embryos. (A-H) Whole mount in situ hybridizations of embryos with dnd antisense RNA probe at the indicated stages. (D) is a high magnification view of ectopic dndRNA containing granules in somatic cells. Note that the RNA is detected exclusively in PGCs from dome stage onwards (F). (I and J) nos-1 expression at $24 \mathrm{hpf}$ in embryos injected with the indicated MOs (200 pg) plus RNAs (1.7 x 10-16 moles). Expression of nos- 1 is lost in embryos coinjected with dnd MO and control GFP globinUTR RNA (Weidinger et al., 2003). 
Shortly after fertilization, maternally provided dead end RNA is present in numerous granules distributed throughout the cortex of the one cell stage embryo (Figure 1-6 A). During the later phase of the first cell cycle, these granules disappear from the animal pole of the embryo and concentrate at the vegetal part of the blastomere (Figure 1-6 B). Subsequently, dead end RNA accumulates at the distal parts of the first two cleavage furrows (Figure 1-6 C). A substantial fraction of maternal dead end RNA is not incorporated into the PGCs and remains in somatic cells up to early gastrulation stages (Figure 1-6 D and E). This and the following expression pattern during blastula, gastrulation and segmentation stages is similar to that of vasa RNA, which is known to reside within the zebrafish germ plasm (Figure 1-4, Figure 1-6 E-H, (Knaut et al., 2000; Yoon et al., 1997)).

Strikingly, in contrast to control, germ cells depleted of Dead end protein by injection of a specific morpholino antisense oligonucleotide were immotile and lost nos-1 expression at $24 \mathrm{hpf}$ indicating an important role of dead end in early germ cell development (Weidinger et al., 2003).

\subsection{Aim of this thesis}

The identification of the mechanisms governing PGC migration is a fundamental question in Developmental Biology. The identification of SDF-1/CXCR4 signaling as a key pathway guiding zebrafish PGCs towards their targets provided an answer to this question in one organism. Thereafter, it was important to check whether this pathway represent a conserved mechanism for directional PGC migration. In the first part of this thesis we addressed this question by determining the role of CXCR4 and SDF-1 in germ cell migration in different organisms.

In the second part of this thesis I was focusing on the other aspect of germ cell development, namely the molecular mechanisms underlying germ cell motility and fate maintenance. Here, the function a novel germ plasm component, which is essential for these processes, was analyzed. 


\section{Results}

\subsection{The Role of the Chemokine SDF-1 in Avian and Murine Germ Cell Migration}

\subsubsection{Identification of Chicken SDF-1}

Avian and reptile primordial germ cells (PGCs) are transported by the vascular system to the region of the gonad where they exit the blood vessels and migrate into the genital ridge. The mechanisms that direct the PGCs along this route are largely unknown. Considering recent evidence implicating SDF-1 signaling in guiding germ cell migration in zebrafish (Doitsidou et al., 2002), SDF-1 is a good candidate molecule for providing PGCs with directional cues in these organisms. To investigate this point, the chick SDF-1 cDNA was cloned and two transcripts were identified, which were termed SDF- $1 \alpha$ and SDF-1 $\beta$. These two transcripts are identical except for the Cterminal domain in which the $\beta$ form is 42 amino acid longer. SDF-1 amino acid sequence alignment of chicken, mouse, rat, human, Xenopus laevis and zebrafish shows extensive conservation of the chick SDF-1 with its mammalian counterparts (Figure 2-1 A and B). For example, the chicken SDF-1 $\alpha$ protein is $90 \%$ identical to the mature mouse SDF-1 $\alpha$ (identical residues in respect to chicken SDF-1 $\alpha$ are indicated in black). Six residues that are essential for binding to glycosaminoglycans (i.e. Lys ${ }^{1}$ $\mathrm{Lys}^{24}, \mathrm{His}^{25}$, Lys ${ }^{27}, \mathrm{Arg}^{41}$, Lys ${ }^{43}$ ) (Figure 2-1 A, arrowheads) (Amara et al., 1999; Sadir et al., 2001) as well as the $\mathrm{R}^{12} \mathrm{FFESH}$ (Arg ${ }^{12}$ PhePheGluSerHis) motif, (Figure 2-1 A, stars) proposed to be an important initial docking site of mouse SDF-1 to its receptor (Crump et al., 1997), are identical except $\mathrm{His}^{17}$ which is replaced by a similar amino acid Asn. The chicken SDF-1 $\beta$ protein is more similar in length to the recently cloned rat SDF-1 $\gamma$ for which a function has not been assigned yet (Gleichmann et al., 2000). The similarity between the mouse and the chick proteins at the primary sequence level can be extended by way of calculation, to imply conservation at the level of the tertiary structures (Figure 2-1 C). To visualize these structural differences, the backbones of mouse SDF- $1 \alpha$ crystal structure (blue) and modeled chicken SDF- $1 \alpha$ tertiary structure (red) were superimposed and side chains of non-identical residues were drawn. The 
overlay shows extensive similarities $\left(R M S D_{\text {backbone }}=0.56\right)$ between these two structures. The residues that differ between the chicken SDF-1 $\alpha$ and the mouse SDF$1 \alpha$ do not critically change the $\alpha-\beta-\beta-\beta-\alpha$ topology of the protein. The main conformational differences are in the length of the first and third $\beta$-sheet.

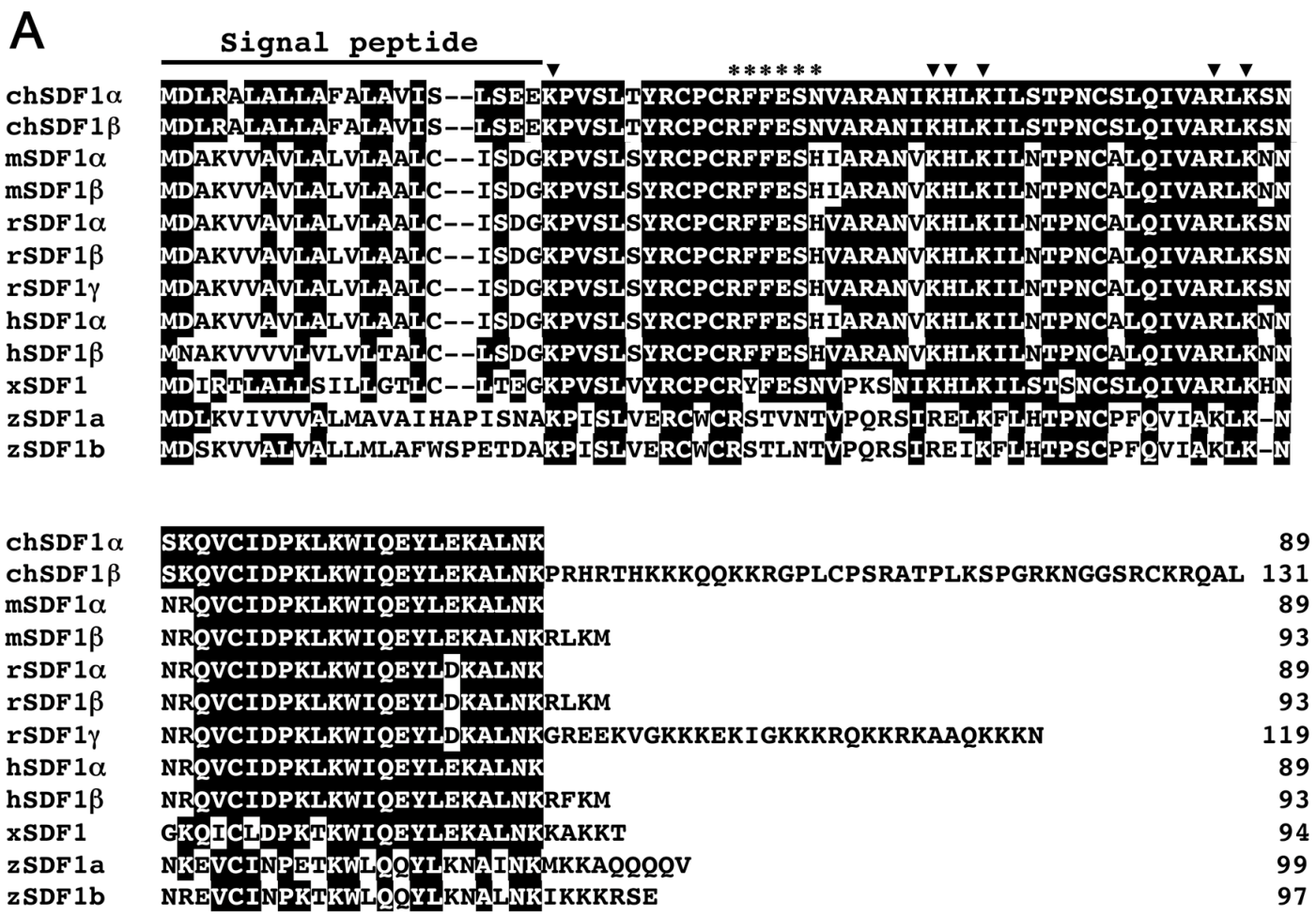

B

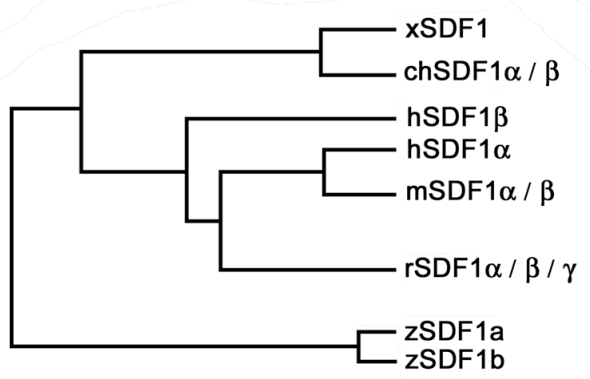

C

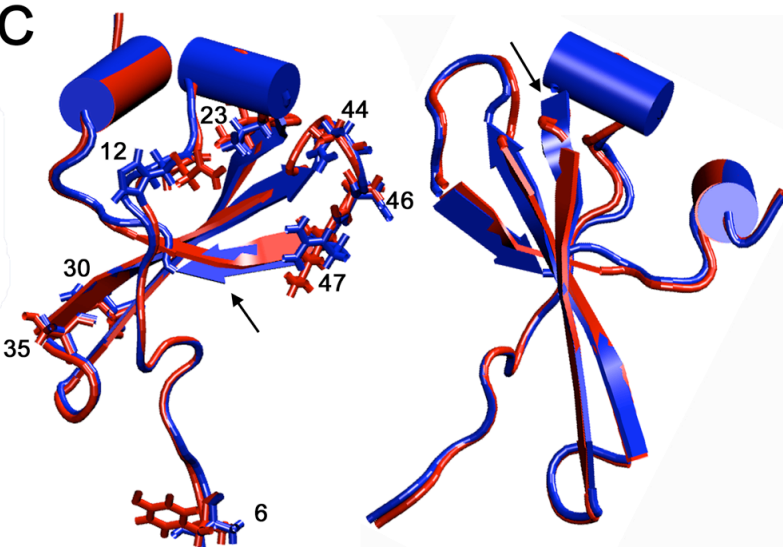

Figure 2-1: (A) SDF-1 amino acid sequence alignment of chicken (chSDF1 $\alpha$ and chSDF1 $\beta$ ), mouse (mSDF1 $\alpha$ and mSDF1 $\beta$ ), rat (rSDF1 $\alpha, \operatorname{rSDF} 1 \beta$ and $\mathrm{rSDF}_{1} \gamma$ ), human (hSDF1 $\alpha$ and hSDF1 $\beta$ ), Xenopus laevis (xSDF1) and zebrafish (zSDF1a and zSDF1b) shows extensive conservation of the chick SDF- $1 \alpha$ with its mammalian counterparts including essential residues for binding to CXCR4 and glycosaminoglycans (identical residues in respect to chicken SDF-1 $\alpha$ 
are indicated in black). (B) The unrooted phylogenetic tree of SDF-1 homologues shows diversion of zebrafish SDF-1 from the other species. (C) Modelling of the chicken SDF-1 $\alpha$ was performed using the mouse SDF-1 $\alpha$ crystal structure (Ohnishi et al., 2000) as an initial template for the backbone structure. Visualization of structural differences of the backbones of mouse SDF- $1 \alpha$ crystal structure (blue) and modeled chicken SDF-1 $\alpha$ tertiary structure (red).

\subsubsection{Chick SDF-1 is Expressed in Positions Where PGCs are Found During the Last Stages of Their Migration}

To determine whether SDF-1 and CXCR4 play a role in chicken PGC migration, the expression pattern of the chicken sdf-1 and cxcr4 RNAs relative to the position of the PGCs and their migration path was examined at different stages. The PGCs were detected by employing a cocktail of the chick vasa (cvh) and dead end ( $d n d)$ probes, while sdf-1 was detected using a probe recognizing both the $\alpha$ and the $\beta$ forms (see Material and Methods). At stage $\mathrm{HH} \mathrm{6,} \mathrm{sdf-1} \mathrm{is} \mathrm{expressed} \mathrm{in} \mathrm{the} \mathrm{posterior} \mathrm{region} \mathrm{of} \mathrm{the}$ ectoderm and mesoderm (Figure 2-2 $\mathrm{K}$ and $\mathrm{P}$ ) but not in the hypoblast of the germinal crescent, the site where most PGCs are located (Fig. $2 \mathrm{~A}$ and $2 \mathrm{~F}$ ). Later in development, during the first phases of somitogenesis, the PGCs migrate out of the hypoblast and enter the developing vascular network (Figure 2-2 F and $G$, arrowheads). At this stage, a few PGCs are frequently found in the developing head (data not shown). As the heart starts to beat ( $\mathrm{HH} 11)$, PGCs are transported passively by the blood stream and are distributed throughout the entire vascular network (Niewkoop and Sutasurya, 1979). Finally, between embryonic stage $\mathrm{HH} 15$ and $\mathrm{HH} 23$, PGCs start to transmigrate the vascular endothelium and migrate within the lateral plate mesoderm (Ipm) towards the genital ridge (Figure 2-2 C-E and $\mathrm{H}-\mathrm{J}$ ).

Analysis of the spatio-temporal expression of $s d f-1$ revealed a strong correlation between $s d f-1$ expression domains and the position of the PGCs during different developmental stages. During HH 8-10, SDF-1 expression becomes restricted to the posterior part of the embryo and to the head region (Figure 2-2 $Q$ and $L$ ), thus raising the possibility that SDF-1 is responsible for the localization of some PGCs to the developing head. As expression in the head region is strongly reduced at stage $\mathrm{HH} 15$ (data not shown), $s d f-1$ is expressed in a broad area of the posterior part of the embryo in the lateral plate mesoderm where the germ cells are found after leaving the blood vessels (Figure 2-2 C, H, M and R). In the following stages, sdf-1 expression becomes stronger and more spatially restricted in the lateral plate mesoderm. Thus, during later development, the expression pattern of $s d f-1$ becomes gradually overlapping with the sites at which PGCs are found (Figure 2-2 D, E, I, J, N, O, S and 
$\mathrm{T})$.

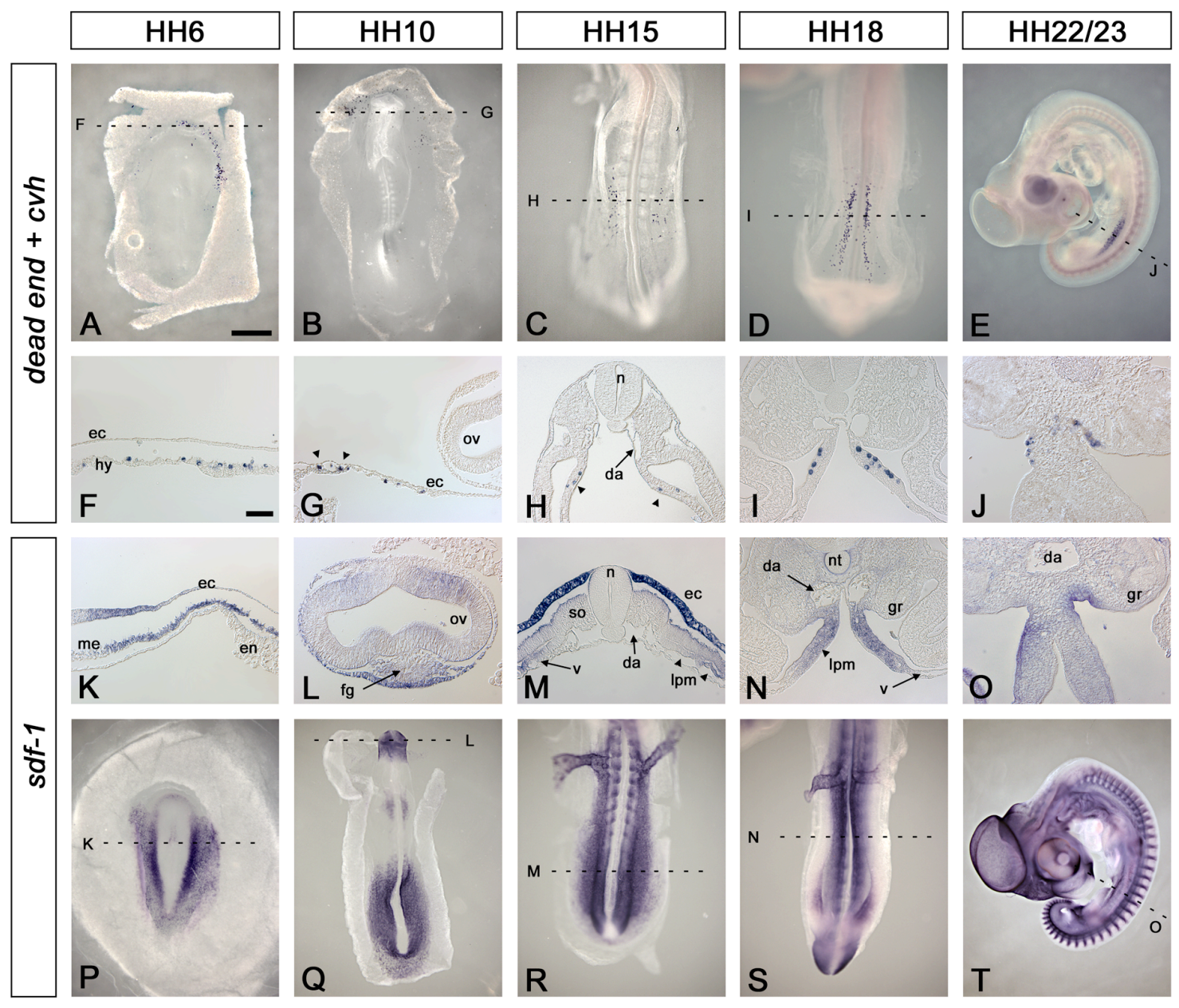

Figure 2-2: Correlation between sdf-1 expression and the position of the germ cells. (A-E) Whole mount in situ hybridization pictures of chicken embryos stained with PGC marker dead end and $c v h$ or (P-T) sdf-1. ( $F-O)$ Sections from the corresponding embryo performed at the level indicated by the black dashed line. (A, B, F, G) PGCs marked by dead end and $c v h$ are located in the germinal crescent within the hypoblast at stage $\mathrm{HH} 6$ and within forming blood vessels (arrowhead and insert) at stage $\mathrm{HH}$ 10. (K, L, P, Q) At these stages sdf-1 is expressed more posterior in the ectoderm and mesoderm and later additionally in the head region. ( $\mathrm{C}$ and $\mathrm{H}$ ) At $\mathrm{HH}$ 15, circulating PGCs (arrowhead) leave the vesicular endothelium and migrate within the lateral plate mesoderm. ( $\mathrm{M}$ and $\mathrm{R}$ ) $s d f-1$ is expressed in the lateral plate mesoderm and in the ectoderm while expression in the head region is almost completely diminished (data not shown). (D, E, I, J) Germ cells within the lateral plate mesoderm migrate towards the genital ridge between $\mathrm{HH} 18$ and $\mathrm{HH}$ 23. ( $\mathrm{N}, \mathrm{O}, \mathrm{S}, \mathrm{T}$ ) Expression of sdf-1 within the lateral plate mesoderm (arrowhead) becomes more restricted and overlaps with the position of the germ cells. Indicated are dorsal aorta (da), ectoderm (ec), endoderm (en), foregut (fg), genital ridge (gr), hypoblast (hy), lateral plate mesoderm (Ipm), neural tube (n), notochord (nt), mesoderm (me), optic vesicle (ov), somite (so), vein (v). The scale bar in A represents $1 \mathrm{~mm}$ in A and P, 
$0.8 \mathrm{~mm}$ in $\mathrm{B}$ and $\mathrm{Q}, 0.5 \mathrm{~mm}$ in $\mathrm{C}-\mathrm{D}$ and $\mathrm{R}-\mathrm{S}$ and $1.5 \mathrm{~mm}$ in $\mathrm{E}$ and $\mathrm{T}$. The scale bar in $\mathrm{F}-\mathrm{O}$ represents $200 \mu \mathrm{m}$ and in insert $600 \mu \mathrm{m}$.

The correlation between the position of the PGCs during later stages of migration and the expression pattern of SDF-1 raised the possibility that SDF-1 provides the cells with directional cues by activating its receptor, CXCR4, expressed by the migrating cells. To examine this supposition, the distribution of cxcr4 mRNA was examined by in situ hybridization. At stage $\mathrm{HH} 4$ and $\mathrm{HH} 8, c x c r 4$ is weakly expressed in the germinal crescent, where PGCs reside (Figure 2-3 A and B, arrowheads). Before stage $\mathrm{HH} 14$, cxcr4 is widely expressed in the lateral plate mesoderm (data not shown).
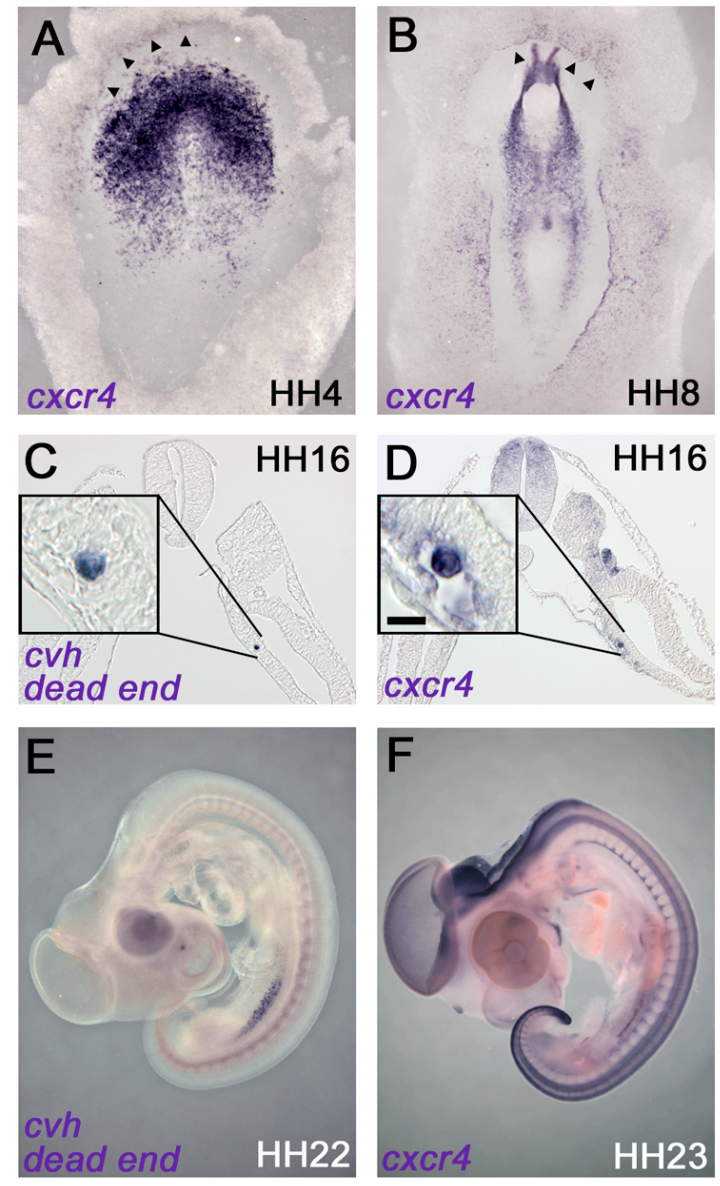

Figure 2-3: cxcr4 is expressed in the germinal crescent and in cells with typical morphological characteristics of PGCs in the lateral plate mesoderm. (A and B) At stage $\mathrm{HH} \mathrm{4-8,} \mathrm{cxcr4} \mathrm{is}$ expressed in low amount in the germinal crescent, the site where germ cells are (arrowheads). (C) At stage HH 16 PGCs expressing dead end and $c v h$ are located in the lateral plate mesoderm. (D) At this stage cells located in the lateral plate mesoderm showing the typical morphology and size of germ cells express cxcr4. (E and F) At stage HH 23 PGCs expressing dead end and cvh are located in the region of the gonad (E) and cxcr4 is expressed in 
numerous tissues including the region of the gonad $(F)$. The scale bar in $B$ represents $280 \mu \mathrm{m}$ in $A$ and $B, 200 \mu \mathrm{m}$ in $C$ and $D, 17 \mu \mathrm{m}$ in inserts and $0.9 \mathrm{~mm}$ in $E$ and $F$.

Significantly, at the time of PGC migration, cxcr4 positive cells can be clearly detected showing the typical morphology (large cell size, 14-17 $\mu \mathrm{m}$ ) and location characteristic of PGCs at this stage (Figure 2-3 C and D). At the time PGCs are colonizing the gonad (Figure 2-3 E), cxcr4 is expressed in numerous tissues whereas mRNA expression in the region where the germ cells reside is significantly reduced (Figure 2-3 F).

\subsubsection{PGCs Can Be Attracted Towards a Source of SDF-1 $\alpha$}

To directly test the notion that SDF- 1 can attract chick PGCs, SDF- $1 \alpha$ and SDF-1 $\beta$ were ectopically expressed and the ensuing PGC response was examined. Aggregates of Cos 7 cells, co-transfected with either the $\alpha$ or $\beta$ forms of SDF-1 and GFP, were implanted into chicken embryos at stage $\mathrm{HH} 4$ and $\mathrm{HH} 10$ at different regions (Figure 2-4 A). Embryos manipulated at stage $\mathrm{HH} 4$ were cultured until stage $\mathrm{HH}$ 10, at which time the PGC localization relative to the site of the implant was examined. Embryos harbouring implants expressing either SDF-1 $\alpha$ and GFP $(n=16)$, SDF-1 $\beta$ and GFP $(n=13)$ or GFP alone as control $(n=10)$ in the area opaca or head region did not show any effect of SDF-1 on germ cell localization as no PGCs were found adjacent to the implants (data not shown). Considering that SDF-1 expressing cells were transplanted adjacent to the region where PGCs reside and close to positions where blood vessel develop, we conclude that at least under the conditions of this experiment, PGCs do not respond to SDF-1 between stages $\mathrm{HH} 4$ and $\mathrm{HH} 10$.

To explore the possible function of SDF-1 in germ cell migration during later stages, embryos were similarly manipulated at stage $\mathrm{HH} 10$ and analysed at stage $\mathrm{HH} 17$ (Figure 2-4 B-G, at these stages all embryos showed high numbers of PGCs in the gonad which responded to the endogenous signals, but these cells can be visualized only from the ventral side of the embryo). 4 of the 13 embryos containing implanted Cos 7 cells that express SDF-1 $\alpha$ and GFP (Figure 2-4 B and D) showed ectopic dead end and cvh labelled PGCs exactly and exclusively at the position of the GFP-labelled graft (Figure 2-4 $\mathrm{C}$ and $\mathrm{E}$ ). This result was further validated by sectioning the embryos and confirming the overlapping localization of the SDF- $1 \alpha$ source and the attracted PGCs (data not shown). In contrast, none of the embryos in which SDF-1 $\beta /$ GFP- or GFP- expressing cells were implanted showed PGCs in close proximity to the graft (n $=17$, data not shown and $n=17$, Figure 2-4 $F$ and $G$, respectively). Taking into 
consideration that the exogenous SDF- $1 \alpha$ source has to be precisely positioned near a blood vessel such

A

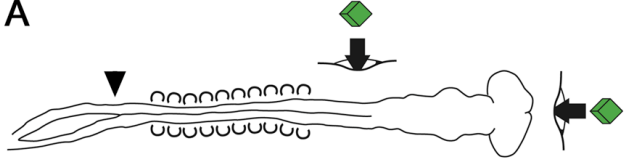

\section{Transfected Cos-7 cell implantation}
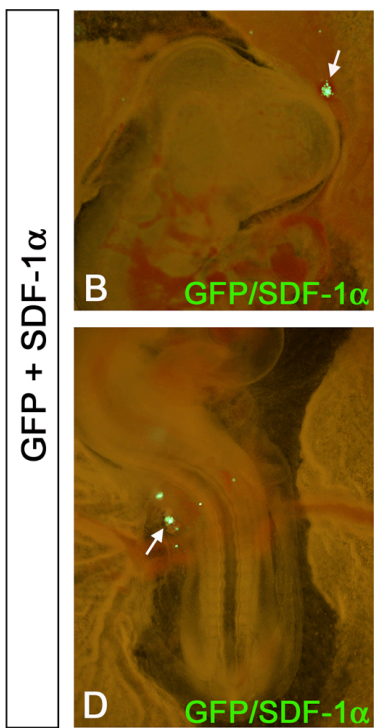

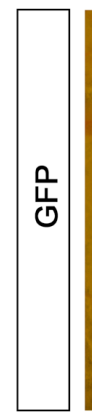
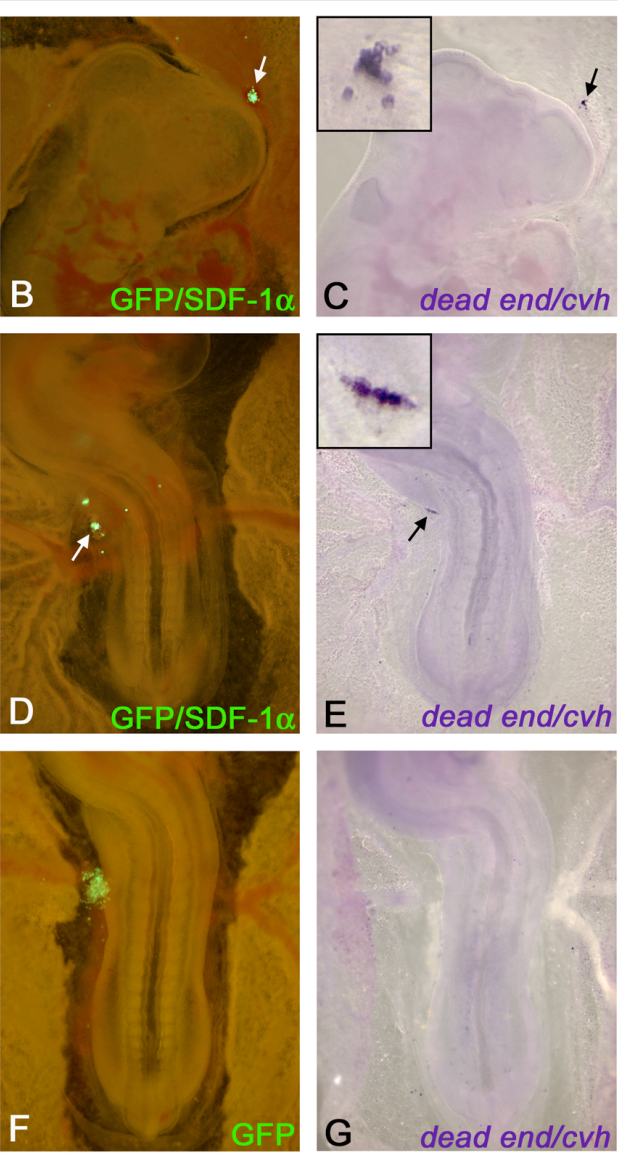

H
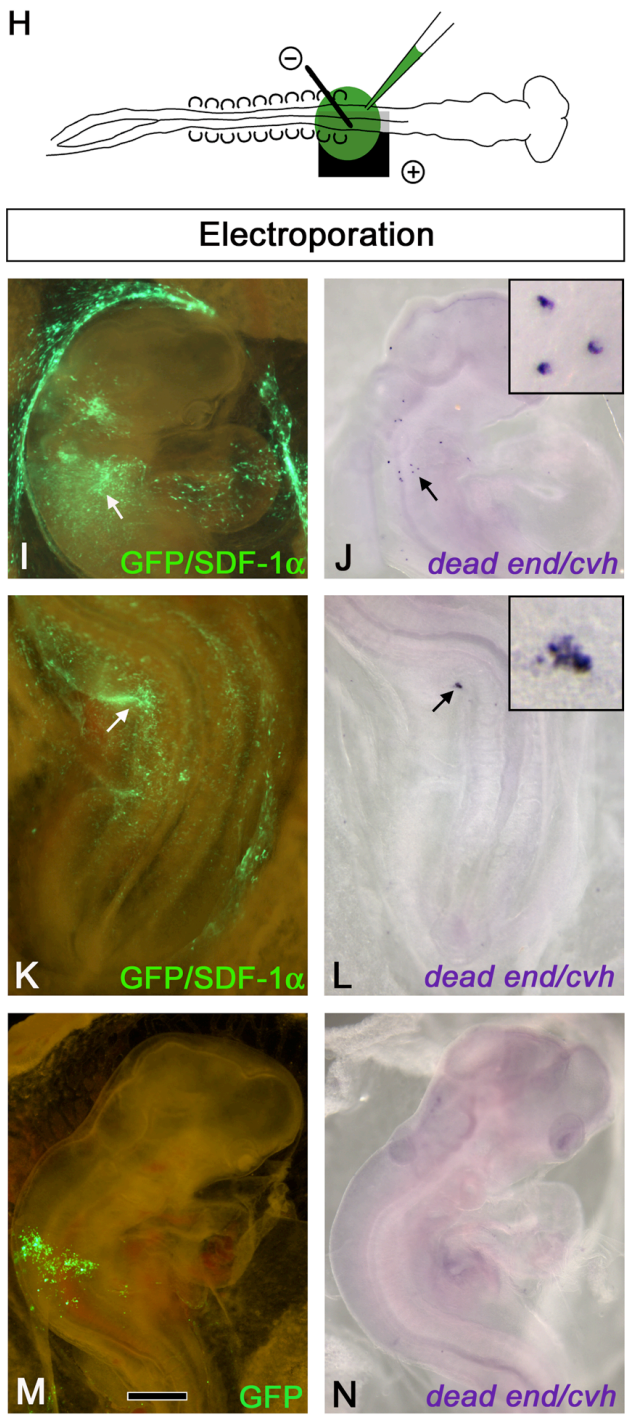

Figure 2-4: Germ cells are attracted towards ectopically expressed SDF-1 $\alpha$. (A) Aggregates of Cos 7 cells expressing either SDF-1 $\alpha$ and GFP, SDF-1 $\beta$ and GFP or GFP alone were implanted at different anterior-posterior position into the chicken embryo at stage $\mathrm{HH} 10$. Embryos were cultured until stage $\mathrm{HH} 17$ and after in situ hybridization using the PGC markers dead end and $c v h$ analysed for the position of germ cells relative to the graft. Arrowhead indicates region of the future gonad. (B, C, D, E) GFP and SDF-1 $\alpha$ expressing Cos 7 cells (white arrow) attracted numerous germ cells (insert), which are marked with dead end and cvh (dorsal view). ( $F$ and G) GFP expressing Cos 7 cells do not attract germ cells. (H) CMV-SDF$1 \alpha$ and CMV-GFP or CMV-GFP alone were co-electroporated at different positions into the chicken embryo, cultured until stage $\mathrm{HH} 17$ and analysed for the position of the PGCs relative to cells expressing high levels of SDF-1 $\alpha$. (I, J, K, L) Germ cells (insert)are attracted to areas of CMV-GFP and CMV-SDF-1 $\alpha$ electroporated cells (white arrow). (M and N) Germ cells are not attracted to areas of CMV-GFP electroporated cells. Insert shows PGCs from the area 
indicated by the arrow. All embryos showed high numbers of PGCs in the gonad, which were attracted by the endogenous signals (visible from ventral side view only, data not shown). The scale bar in M represents $515 \mu \mathrm{m}$ in B and C, $500 \mu \mathrm{m}$ in D-G and I-N.

that it can subsequently be presented on the luminal side to circulating PGCs and that it has to compete with the endogenous SDF-1 $\alpha$, the number of embryos showing these results supports the idea that SDF- $1 \alpha$ acts as a chemoattractant for chicken PGCs.

To confirm this finding, we employed an independent method, in which we electroporated chicken embryos at stages $\mathrm{HH} 4$ and $\mathrm{HH} 10$ with SDF-1 $\alpha$ and GFP or GFP alone to generate an ectopic SDF-1 $\alpha$ source at different positions (Figure 2-4 H). These embryos were cultured in EC-whole embryo culture until stage $\mathrm{HH} 17$. Indeed, $19.1 \% \pm 5.5 \%$ (s.e.m. standard error of the mean) of PGCs in embryos electroporated with SDF- $1 \alpha$ and GFP ( $n=10$ embryos, $n=519$ cells) reached the region of high SDF$1 \alpha$ expression (marked by high GFP expression) away from the region of the gonad (Figure 2-4 I-L). In contrast, only $1.7 \% \pm 0.6 \%$ of the PGCs in GFP electroporated control embryos ( $n=20$ embryos, $n=1472$ cells $P<0.0001$ ) were found within high GFP expressing regions (Figure 2-4 $\mathrm{M}$ and $\mathrm{N}$ ).

These data, along with sdf-1 expression pattern, clearly implicate SDF-1 $\alpha$, but does not support a role for SDF-1 $\beta$, in guidance of migrating PGC in the chick. Interestingly, in zebrafish too, only one of the two SDF-1 proteins (SDF-1a which differs from SDF$1 \mathrm{~b}$ in its $\mathrm{C}$-terminus) is considered to be relevant for activating CXCR4b in the PGCs (Doitsidou et al., 2002). According to our findings, the function of SDF-1 as a PGC attractant in the chick appears to be temporally restricted to the second phase of PGC migration, the stage at which germ cells leave the vascular network and migrate towards the genital ridge $(\mathrm{HH} 15-29)$.

\subsubsection{Mouse PGCs Transmigrate Through the Hindgut Epithelia Exclusively in the Region of SDF-1 Expression}

Analogous to our findings in chick, mouse SDF-1 has been recently shown to be essential for PGC migration from the hindgut via the mesenchyme to the gonad (Ara et al., 2003; Molyneaux et al., 2003), but is not required for the earlier migration phases. Based on these results, it was proposed that during early steps of PGC migration SDF1 might be complemented by other chemokines or cytokines that play a redundant role (Ara et al., 2003). To address this notion, we examined the expression pattern of mouse SDF- $1 \alpha$ and SDF-1 $\beta$ with respect to the position of the germ cells by in situ 
hybridization from developmental stages E8.5 to E11.5. During this time window, the PGCs exit the hindgut and migrate towards the gonad. $s d f-1 \beta$ (and $s d f-1 \alpha$, data not
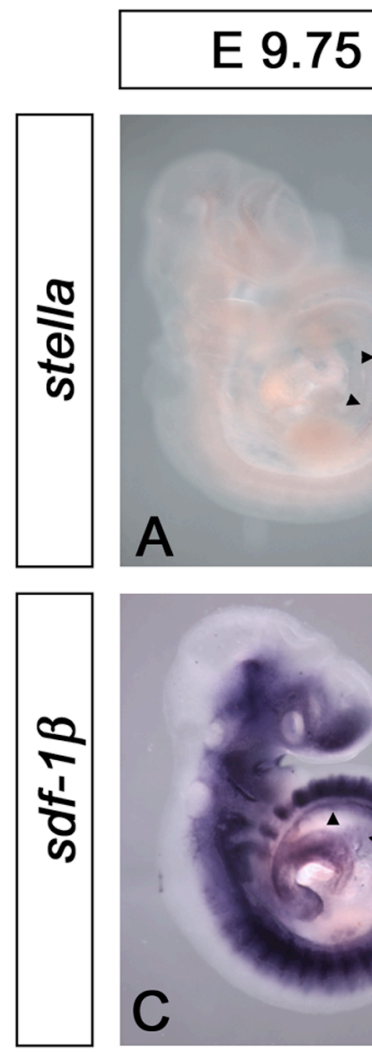
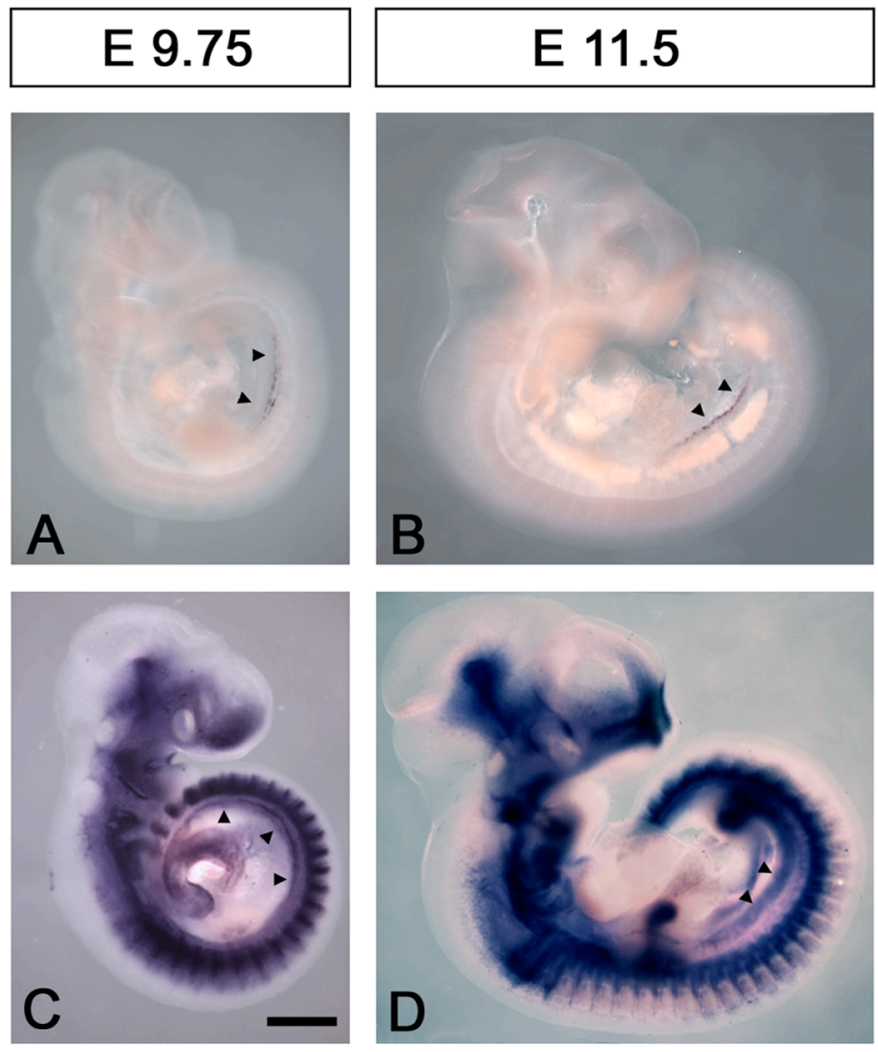

Figure 2-5: Mouse SDF-1 expression correlates with the position of the germ cells

(A) An E9.75 embryo with germ cells (arrowhead) stained by in situ hybridization with stella at the onset of directional PGCs migration from the dorsal body wall towards the genital ridge. (B) At E11.5, germ cells (arrowhead) are found within the genital ridge. (C and $D)$ In embryos of the same stages as in $(A)$ and $(B) s d f-1 \beta$ is expressed over the whole anterior-posterior axis along the germ cell migration route and in the gonad (arrowhead). The scale bar in $C$ represents 1 $\mathrm{mm}$ in $\mathrm{A}$ and $\mathrm{C}$ and $2.5 \mathrm{~mm}$ in $\mathrm{B}$ and $\mathrm{D}$.

shown) is expressed along the migratory route in the dorsal mesentery and in the genital ridge (Figure 2-5 and Figure 2-6 D-I).

However, at E9, before the PGCs migrate dorsally towards the point where they exit the gut, $s d f-1 \beta$ (and $s d f-1 \alpha$, data not shown) is expressed in the dorsal half of the hindgut, but is clearly absent from the ventral half (Figure 2-6 A and $A^{\prime}$ ), where PGCs are predominantly found at this stage (Figure 2-6 $C$ and $C^{\prime}$ ). These data show that most PGCs are distant from SDF-1 expression domain prior to the time point at which they migrate dorsally (E9-E9.5). We conclude that SDF-1 does not play a role in guiding the cells anteriorly along the ventral side of the hindgut. The migration of the 
cells to the position adjacent to the genital ridge is therefore guided by other factors.
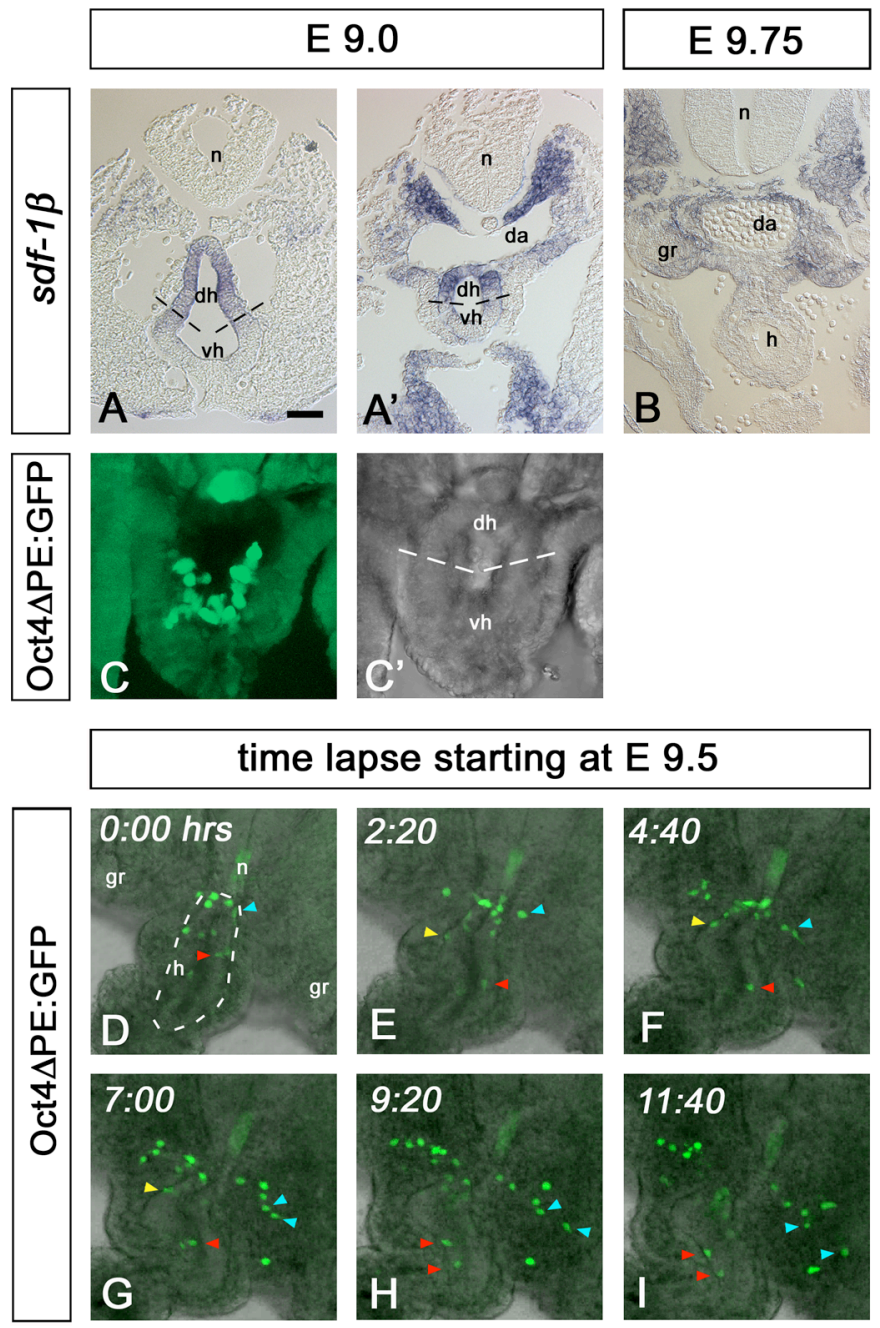

Figure 2-6: Mouse SDF-1 expression correlates with germ cell position from the time PGCs start to emerge from the hindgut. (A and A') Two sections of a stage E9 embryo show sdf-1 $\beta$ staining in the dorsal half of the hindgut but not in the ventral half. Both sections are from the same embryo whereas A is more posterior than A'. (B) Section through the gonad of the E9.75 embryo displayed in Figure $2-5 \mathrm{C}$ shows that $s d f-1 \beta$ is expressed along the PGC migration route in the dorsal mesentery and in the gonad but not anymore in the hindgut. (C) GFP expressing germ cells in cultured hindgut transverse slices are located in the ventral half of the hindgut. (C') shows (C) in bright field. (D-I) Six confocal snapshots from a 11 hours 40 minutes long time lapse movie showing GFP expressing PGCs in Oct4 $\triangle \mathrm{PE}: \mathrm{GFP}$ transgenic mouse which emerge from the dorsal-most part of the hindgut and migrate towards the genital ridge (blue arrowhead). Germ cells located in the ventral half of the hindgut (red and yellow arrowheads) do not transmigrate the gut epithelia and eventually die (supplementary Movie 1). Indicated are dorsal aorta (da), dorsal hindgut (dh), genital ridge (gr), hindgut $(\mathrm{h})$, neural tube 
(n), and ventral hindgut (vh). The scale bar in $C$ represents $1 \mathrm{~mm}$ in $A$ and $C$ and $2.5 \mathrm{~mm}$ in $B$ and D. The scale bar in A represents $200 \mu \mathrm{m}$ in A-B, $300 \mu \mathrm{m}$ in D-I and $360 \mu \mathrm{m}$ in C and C'.

To examine the events occurring at this stage more directly, we monitored the behaviour of GFP-expressing mouse germ cells in cultured transverse slices (Anderson et al., 1999; Molyneaux et al., 2001) from E9.5 hindgut by time-lapse microscopy (Figure 2-6 D-I). We found that the germ cells emerge exclusively from the dorsal-most part of the hindgut (blue arrowhead), where sdf-1 is expressed, whereas ventrally positioned PGCs move while colliding with the epithelium but do not transmigrate through it (red and yellow arrowhead) and eventually die (Molyneaux et al., 2001). Together, these results are consistent with the idea that SDF-1 is required specifically for directing the dorsal migration of PGCs to the position in the hindgut from which they migrate into the mesentery. Our data suggest a common function of SDF-1 in promoting PGC transmigration through epithelial like structures such as the hindgut epithelium in mouse and the endothelium in chick. 


\section{2 dead end is Required for Primordial Germ Cell Migration and Survival}

\subsubsection{Dead end is a novel putative RNA-binding protein, which is localized to perinuclear germ granules}

In a large scale whole mount in situ screen for genes expressed in zebrafish PGCs we identified a novel gene, dead end $(d n d)$. The full-length zebrafish dead end cDNA encodes a protein of 411 amino acids containing a putative single strand RNA binding domain (Prosite database profile PS50102) in its N-terminal half (Figure 2-7).

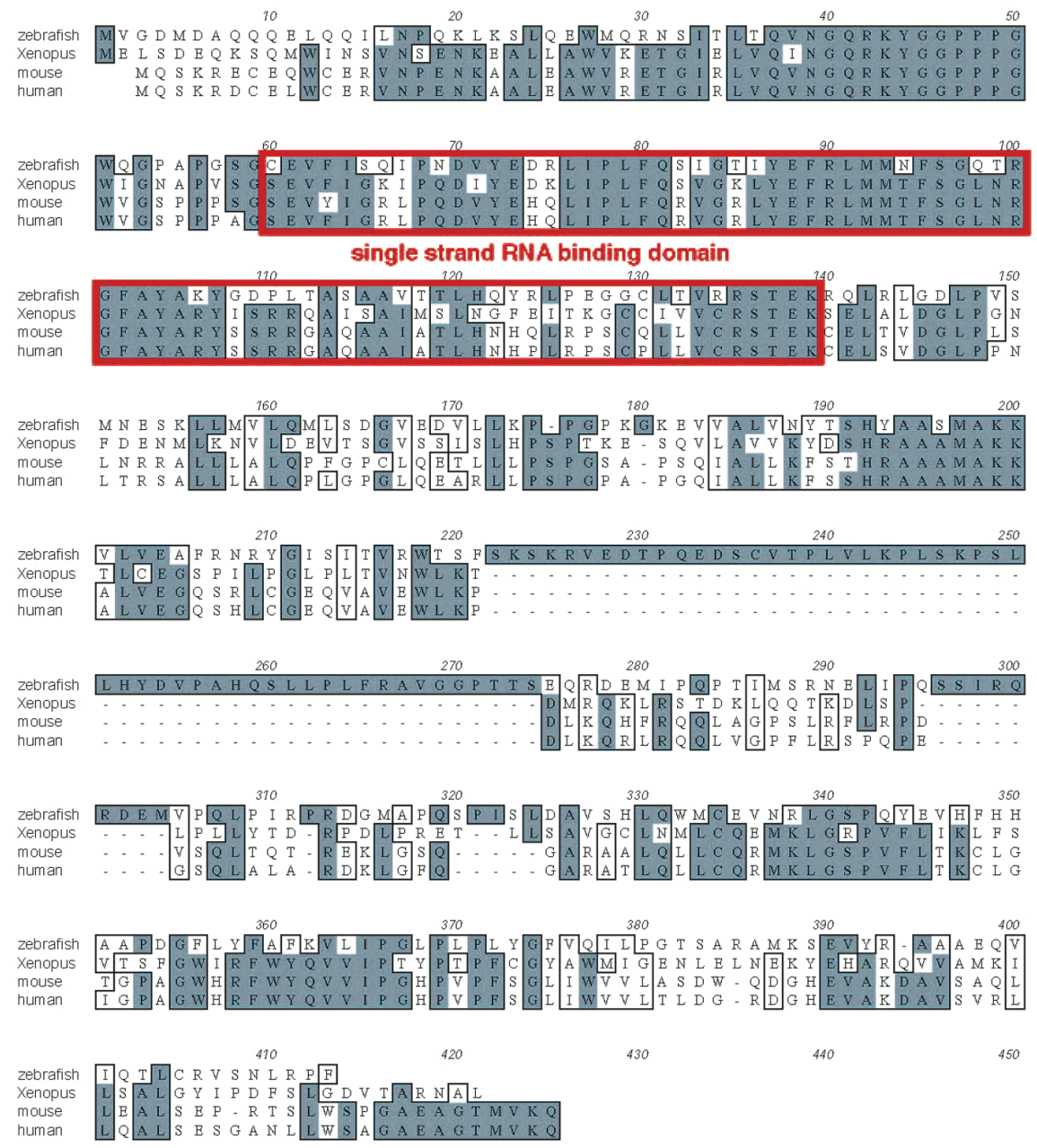

Figure 2-7: Multiple alignment of the zebrafish dead end and orthologs. In the red frame, highly conserved putative RNA binding domain is highlighted. 
This RNA binding motif is found in a large variety of RNA binding proteins such as heterogeneous nuclear ribonucleoprotein particles (hnRNPs), small nuclear ribonucleoprotein particles (snRNPs) and other pre-RNA and mRNA associated proteins. Multible alignment of zebrafish dead end and ESTs or genomic sequences encoding closely related dead end genes in Xenopus laevis, mouse and human shows that the single strand RNA binding motif is conserved $58-59 \%$ between zebrafish and orthologs from other species.

dead end is specifically expressed in germ plasm and primordial germ cells (Weidinger et al., 2003). The expression pattern is similar to that of vasa RNA, which is known to reside within the zebrafish germ plasm (Knaut et al., 2000; Yoon et al., 1997). Northern blot analysis revealed rapid degradation of the maternally provided dnd RNA just after PGC specification at $4 \mathrm{hpf}$ (sphere stage) (Figure 2-8 A). Low levels of RNA persist during embryogenesis, which presumably corresponds to exclusive expression of the gene in the PGCs.
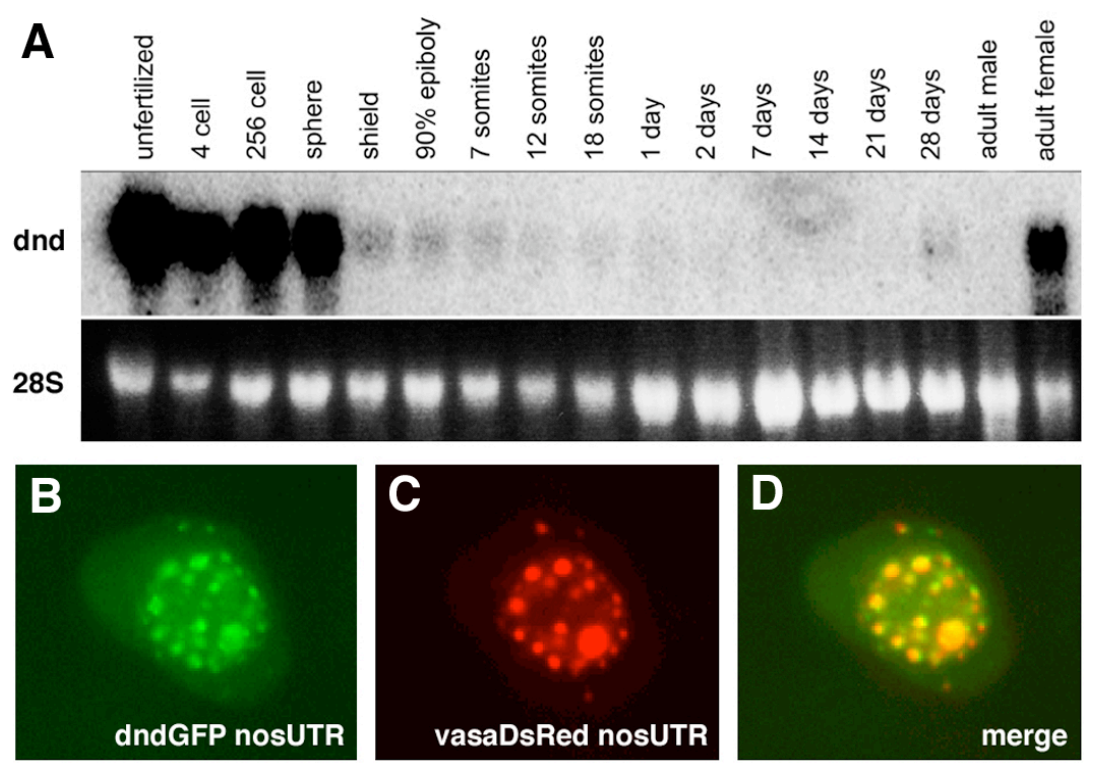

Figure 2-8: Expression and subcellular localization of Dead end. (A) Northern blot analysis using dead end as probe shows that maternally provided dead end is degraded after sphere stage but low level of expression persists during embrogenesis. (B-D) Fluorescent pictures of a PGC in a 10-somite stage embryo coinjected with $100 \mathrm{pg}$ dndGFP nos1-3'UTR (green channel in B) and vasaDsRed nos1-3'UTR (red channel in B). The merge picture in D shows that Vasa and Dead end proteins colocalize to perinuclear germ granules. 
To determine the subcellular localization of the Dead end protein, a Dead end-GFP fusion protein was expressed in the PGCs. As shown in Figure 2-8 B-D, Dead end protein is localized to perinuclear germ granules, which also contain a Vasa-DsRed fusion protein in mid-somitogenesis stage embryos. Thus, Dead end is localized to the same cellular structure where other zebrafish germline-specific proteins (e.g. Vasa and Nanos (Knaut et al., 2000; Koprunner et al., 2001; Yoon et al., 1997)) are found.

\subsubsection{Dead end Overexpression in PGCs and Somatic Tissue Does not Alter Germ Cell Specification and Number}

As described above, germ cells in many organisms are specified by the inheritance of cytoplasmic determinants, the so-called germ plasm. To date, little is known about the mechanism of this process but it is assumed that cells harboring high concentration of germ plasm become PGCs, whereas the fate of cells with low concentration acquire a somatic cell fates. To investigate, if germ cell specification and/or proliferation is influenced by dead end-concentration, we over-expressed dead end in the zebrafish embryo by injection of dead end-globin UTR RNA (over-expression in the whole embryo, $300 \mathrm{ng} / \mu \mathrm{l}$ ) or dead end-nos1 3'UTR RNA (over-expression in the germ cells, $300 \mathrm{ng} / \mathrm{ml}$ ) and compared PGC number at sphere stage (PGCs have just specified) and shield stage (just after PGCs specification, 4 hours post fertilization) and shield stage (6 hours post fertilization) relative to controls (embryos injected with GFP and a non-functional mutated form of dead end (Figure 2-9).

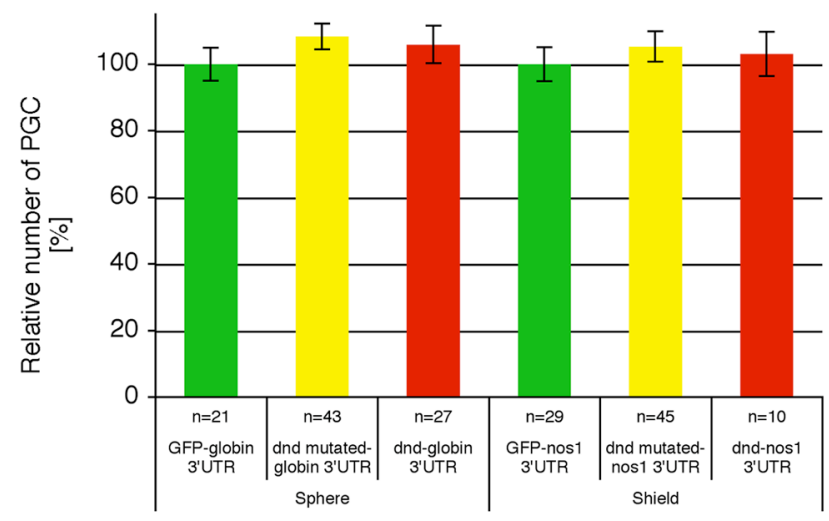

Figure 2-9: Over expression of dead end in the zebrafish embryo does not affect PGC specification or proliferation. 
Over-expression of dead end did not alter the specification or PGC number at sphere and shield stage (Figure 2-9). We therefore conclude that an increased expression of Dead end protein is not sufficient to affect any of these processes.

\subsubsection{Dead end is Required for PGC Migration}

To investigate the function of dead end on PGC development, we knocked down the expression of Dead end protein by injection of dead end-specific morpholino antisense oligonucleotide (MO) into one-cell stage zebrafish embryos. Coinjection of FarnesylGFP-nos1-3'UTR (membran bound GFP) enabled to follow PGC behavior by timelapse microscopy.
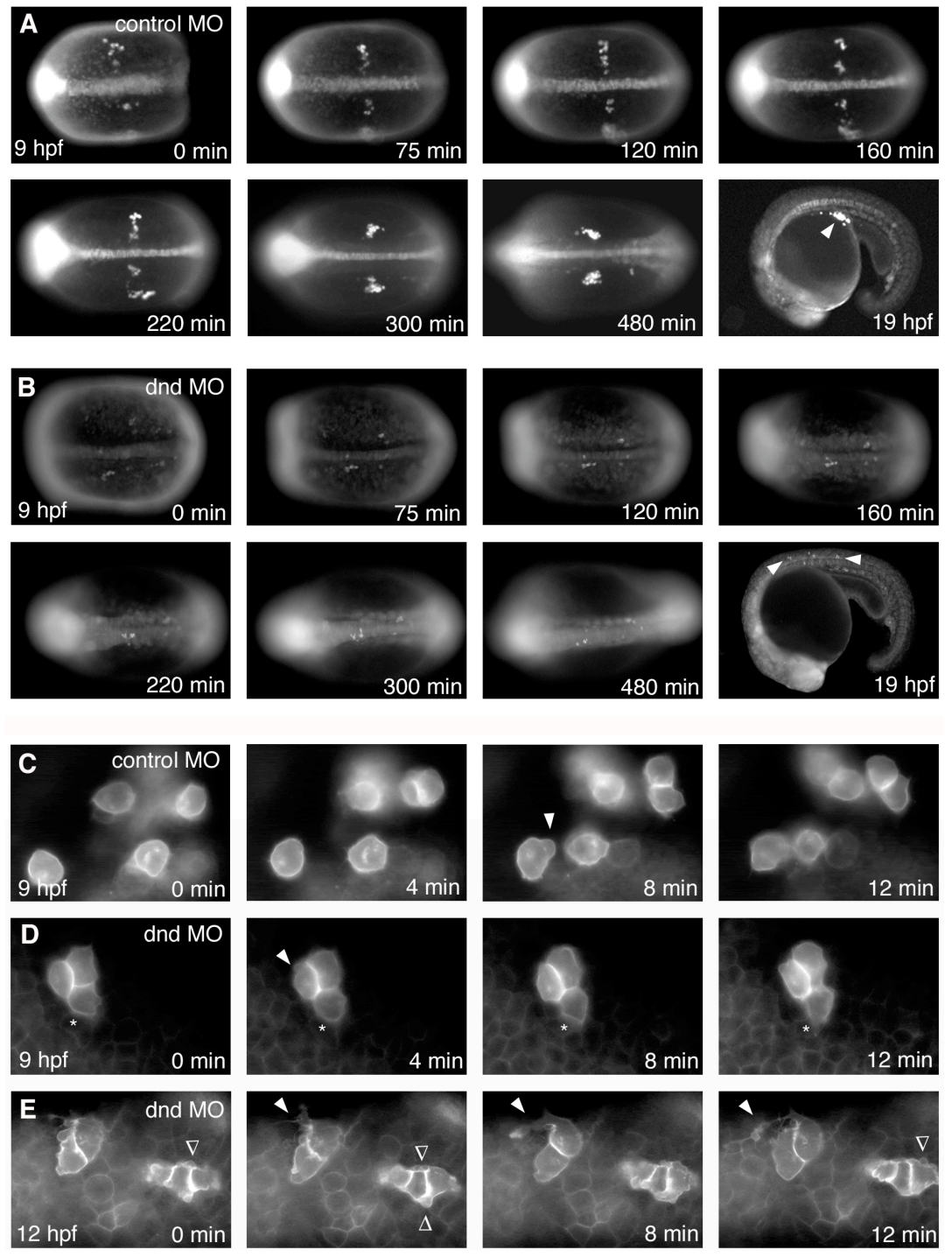
Figure 2-10: Dead end is required for zebrafish PGC migration. Frames taken at the indicated times from time lapse movies showing membrane-localized GFP labeled PGCs in an zebrafish embryo injected with $400 \mathrm{pg}$ control MO or $400 \mathrm{pg}$ dnd MO. (A) PGCs in control MO injected embryos migrate actively, align at the border of the trunk mesoderm, later form to lateral cluster and subsequently migrate dorsally to the region of the 8th to 10th somite. (B) PGCs in dnd MO injected embryos are not motile, move with the gastrulation movements towards the embryonic midline and disappear. (C) Control PGCs migrate actively as individual cells relative to their somatic neighbors. (D) In contrast, at the same developmental stage, dnd knockdown-PGCs do not actively migrate, form stable close cell-cell contacts and do not form long stable protrusions. (E) However, during mid-segmentation stages, Dead end depleted PGCs form atypical long protrusion.

In control MO injected zebrafish embryos (Figure 2-10 A) as in untreated embryos (Weidinger et al., 1999b; Weidinger et al., 2002; Yoon et al., 1997), PGCs start to migrate before gastrulation from four different positions where they are specified and align along the anterior border of the trunk mesoderm, with the exception of the dorsal midline (9 hpf - $11 \mathrm{hpf}$ ). The PGCs then migrate laterally to form two PGC cluster (11 hpf - $13 \mathrm{hpf}$ ). Subsequently, clustered PGCs migrate posteriorly towards the position of the $8^{\text {th }}$ to $10^{\text {th }}$ somite, where they are found at $24 \mathrm{hpf}$ (arrowhead). In dead end MO injected embryos, PGCs do not exhibit active migration. Rather, the germ cells move by the convergence and extension movements together with the somatic tissue and therefore arrive at ectopic positions including the dorsal midline (Figure 2-10 B, arrowhead). In contrast to control embryos, GFP expressing PGCs in dead end MO injected embryos gradually disappear during somitogenesis stages.

To determine the basis for the migration phenotype described above, we examined Dead end depleted PGCs in live embryos on the cellular level and compared their behavior to that in control embryos. In contrast to GFP-labeled PGCs in control-MO injected embryos, which exhibit active migration relative to each other and their somatic neighbors and form stable big pseudopodia (Figure 2-10 C, arrowhead), there is no evidence for active PGC migration in dead end knockdown embryos as PGCs do not move relative to somatic neighbors (Figure 2-10 $D$ and $E$ ). Furthermore, unlike control PGCs, which migrate as individual cells or show loose transient contacts to other germ cells, dead end knockdown PGCs often remain in groups of cells, which maintain in close cell-cell contact (Figure 2-10 D and E). During gastrulation and early somitogenesis, PGCs in dead end knock down embryos form only small transient pseudopodia (Figure 2-10 D), whereas during later segmentation stages more stable atypical long lamellipodia and filopodia can be formed (Figure 2-10 E). However, the later morphological phenotype may reflect indirect effects associated with the dead end knock down (see below). 


\subsubsection{Zebrafish dead end Is Required for PGC Survival}

As mentioned above, while PGCs in which Dead end was knocked down expressed GFP (Figure 2-10 B), all of the GFP-positive PGCs disappeared by the end of the first day of development (Figure 2-10 B and data not shown). To determine the fate of these PGCs, we tracked individual GFP-labeled PGCs in live embryos. We found that in contrast to control-MO injected embryos, all PGCs in dnd-knockdown embryos eventually exhibited the morphological hallmarks of apoptotic cells (Rich et al., 1999), including membrane blebbing and fractionation into small apoptotic bodies (Figure 2-11 A). Although we cannot exclude the possibility that a small number of PGCs assumes a different fate, we conclude that PGCs lacking functional Dead end lose expression of characteristic genes (vasa, nanos-1, data not shown) and eventually die.
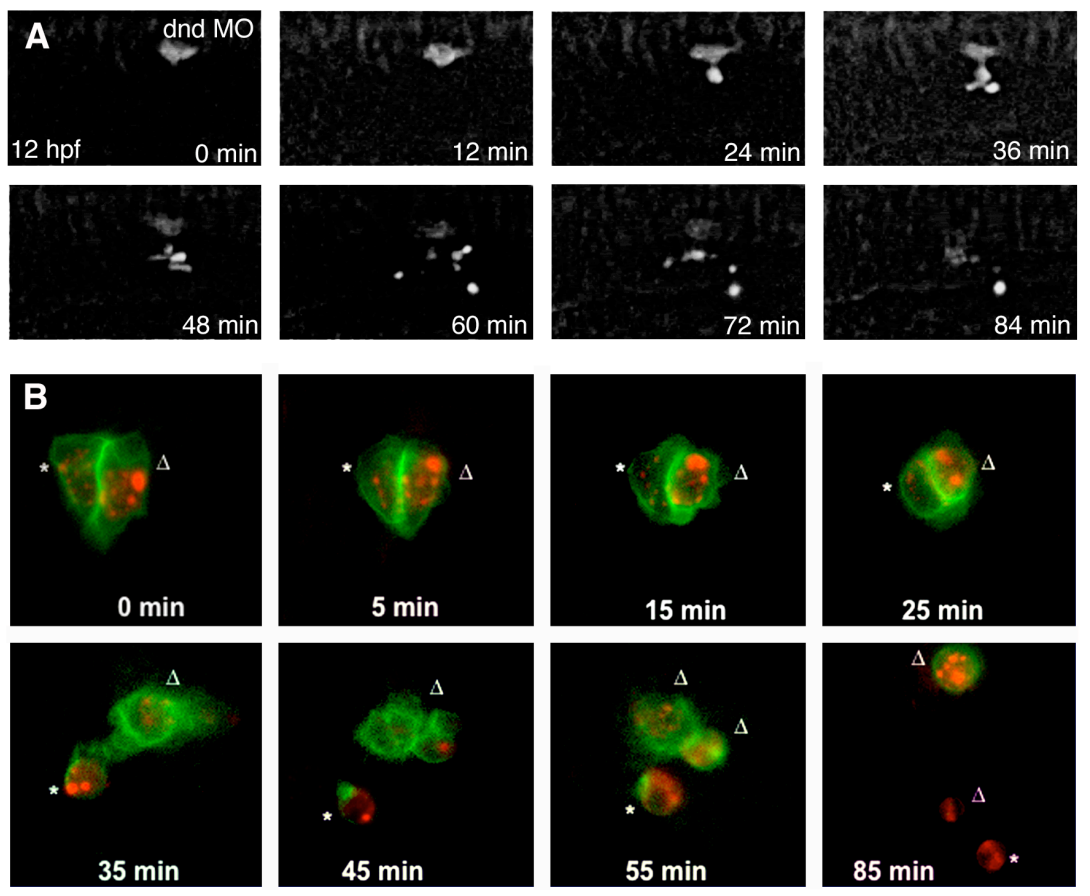

Figure 2-11: Zebrafish dead end is essential for PGC survival. (A) Frames taken at the indicated times from a time-lapse movie that starts at $12 \mathrm{hpf}$ showing GFP labeled PGC in a zebrafish embryo injected with $400 \mathrm{pg}$ dnd MO. PGC is fractionating as it dies and forms numerous apoptotic bodies (B) Two closely attached PGCs labeled by membrane-localized GFP and VasaDsRed fusion protein to visualize perinuclear granules in an embryo injected with $400 \mathrm{pg}$ dnd $\mathrm{MO}$. Note that the perinuclear granules are present in the germ cells until fractionation into apoptotic bodies. 
One of germ cell characteristics are perinuclear granules, a cellular structure where zebrafish germline-specific proteins (e.g. Vasa and Nanos) are found. Perinuclear granules contain multiple putative RNA binding proteins are found in germline cells of many organisms and are associated with nuclear pores in $C$. elegans (Pitt et al., 2000). It has been proposed that germ granules are play an important role in the PGC specific development by regulating gene expression in PGCs post-transcriptionally, by controlling mRNA transport, stability and translation (Houston and King, 2000a; Seydoux and Strome, 1999). As PGCs in Dead end depleted zebrafish embryos do not maintain their fate, it might be possible that these cells transdifferentiate prior to their death. To address this question, we monitored the presence of perinuclear granules in PGCs of Dead end knock down embryos using the vasaDsRed fusion protein to label the granules. The fact that PGCs maintain the perinuclear granule staining until they die indicates that these cells maintain thiere fate at least partially until they die The current understanding of the germline origin in zebrafish has been based on the expression of specific molecular markers such as vasa by cells that arrive at the region of the gonad and expression of the same markers later during gametogenesis. In cxcr4 morphants or mutants, the PGCs exhibit severe migration defects, yet a large proportion of adult cxcr4 mutants is fertile (Knaut et al., 2003). This finding might indicate that a few PGCs, which arrive at the region of the gonad by chance, can found a functional germ cell population. However, there is no evidence that no other cells can potentially contribute to the germline during normal development, or when the number of vasa-expressing cells is reduced. To investigate this aspect, we raised control and dnd $\mathrm{MO}$ injected embryos to adulthood and crossed them with wild-type fish. Remarkably, while on average $84 \%$ of the eggs were fertilized in crosses with controlMO injected males (1333 of 1592 eggs), only $1 \%$ was fertilized by dnd MO males (20 of 1486 , all derived from one male). 14 of 15 dnd MO injected males did not fertilize a single egg in several crosses, while all 7 of the control-MO injected males fertilized eggs at least in one cross. This strong correlation between loss of cells expressing PGC markers like vasa and nos-1 and sterility further corroborates the notion that the only cells capable of populating the germline in the zebrafish gonad are the cells expressing these markers at earlier stages. Indeed, this finding allows for the complete replacement of the germ-line in $d n d \mathrm{MO}$ injectedembryos with that of genetically marked donor embryos by transplantation, an achievement that significantly simplifies the production of maternal effect mutants (Ciruna et al., 2002). 


\subsection{5 dead end Expression is Conserved in Other Vertebrate Species}

While dead end function is clearly crucial for proper development of zebrafish PGCs, no homologous proteins have been described when the work on this thesis was initiated. Nevertheless, ESTs and genomic sequences encoding closely related genes in Xenopus laevis, chick, mouse and human were identified (Figure 2-7). These dead end orthologs are expressed in the germ plasm of Xenopus and in germ cells of mouse and chick (Figure 2-12), implying that they might play a role in germline development in these organisms, too. In Xenopus maternal dead end RNA is present along the cleavage planes at the vegetal pole of early cleavage stage embryos (Figure 2-12 A, arrow) in a pattern very similar to that of Xpat, a germ plasm component in that organism (Figure 2-12 A and B, done by Gilbert Weidinger) (Hudson and Woodland, 1998). Expression of dead end in the mouse also

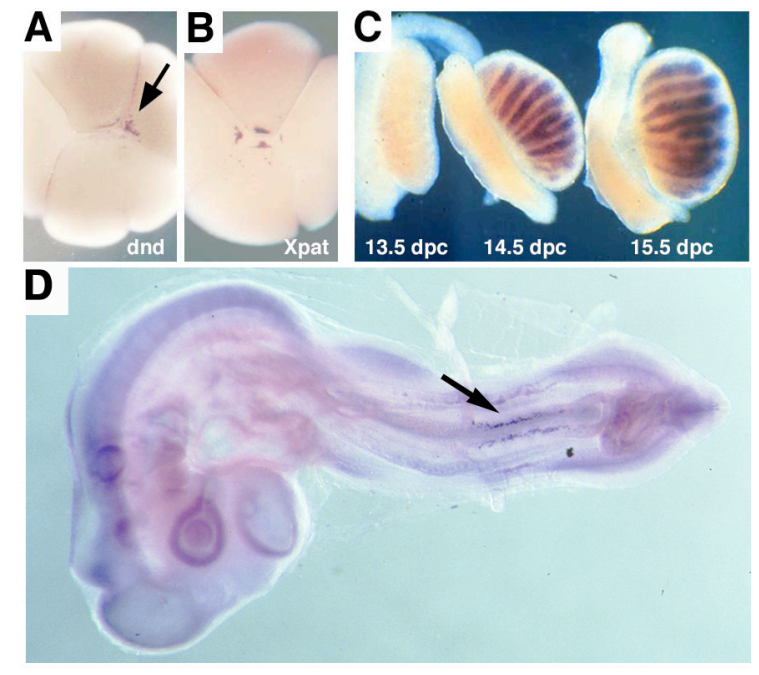

Figure 2-12: dead end orthologs are expressed in germ plasm and germ cells in Xenopus, mouse and chick. (A, B) Vegetal views of Xenopus laevis embryos at the 16-cell stage stained for expression of dead end (arrow in A) and Xpat (B) RNAs. Both are present in aggregates at the cleavage planes where the Xenopus germ plasm resides. (C) Mouse gonads plus attached mesonephroi explanted from embryos at the indicated days post coitum (dpc) stained for expression of dead end RNA. (D) Expression of chick dead end in PGCs (arrow) after their arrival at the region of the gonad (stage 18 according to (Hamburger and Hamilton, 1951))

appeared to be in the germ cells, as seen at $14.5 \mathrm{dpc}$, where expression is very strong within the testis cords (Figure 2-12 C, done by Clare Wise and Robin Lovell-Badge). This expression pattern is reminiscent of the expression pattern of the mouse vasa homolog (mvh), which is expressed in the PGCs as they arrive at the region of the 
gonad (Noce et al., 2001). The chick dead end was expressed in the PGCs, in a similar pattern to that of chick vasa (Tsunekawa et al., 2000) and could be detected in those cells before, during and after their arrival at the gonad (Figure 2-12 D and data not shown). Therefore, based on the similarity in sequence and expression pattern it is likely that dead end plays a general role in germline development in other vertebrates, as well. Interestingly, we failed to identify dead end orthologues in the fully sequenced genomes of Drosophila melanogaster and Caenorhabditis elegans. Specifically, proteins from these invertebrates showing similarity to dead end orthologs show significantly higher degree of similarity to other proteins in vertebrates. This raises the possibility that dead end is the first vertebrate-specific germ plasm component known to be essential for germ cell development.

\subsubsection{Identification of Dead end Interaction Partners}

Whereas the RNA binding domain in Dead end provides an important hint regarding its function, the precise biochemical activity of this protein is unknown. Identification of proteins and RNAs that interact with Dead end could provide clues regarding this question. To identify such molecules we employed yeast-two-hybrid technology and immunoprecipitation to identify putative Dead end interacting proteins and RNAs.

To identify Dead end - protein complexes by yeast-two-hybrid technology, we first produced a PGC specific full-length cDNA library using 635 PGCs from embryos whose germ cells express GFP. This technique has the advantage of immediate freezing of the PGCs following their isolation and therefore maintaining the transcription profile more representative of the in vivo situation as compared to other techniques such as FACS. The mRNA pool was then reverse transcribed, amplified and subsequently cloned into a plasmid vector. With this library, a yeast-two-hybrid screen was performed and 13 positive clones were identified (Figure 2-13 A and chapter Material and Methods).

For the identification of Dead end-RNA or Dead end-protein complexes by immunoprecipitation, we decided to follow the strategy of using a commercially available monoclonal antibody against the HA-tag, a tag that was fused to the Dead end protein. This fusion protein normally interacts with other molecules as judged by its ability to support the survival and migration of PGCs depleted for the endogenous Dead end protein using morpholino antisense oligonucleotides (Figure 2-13 B). 

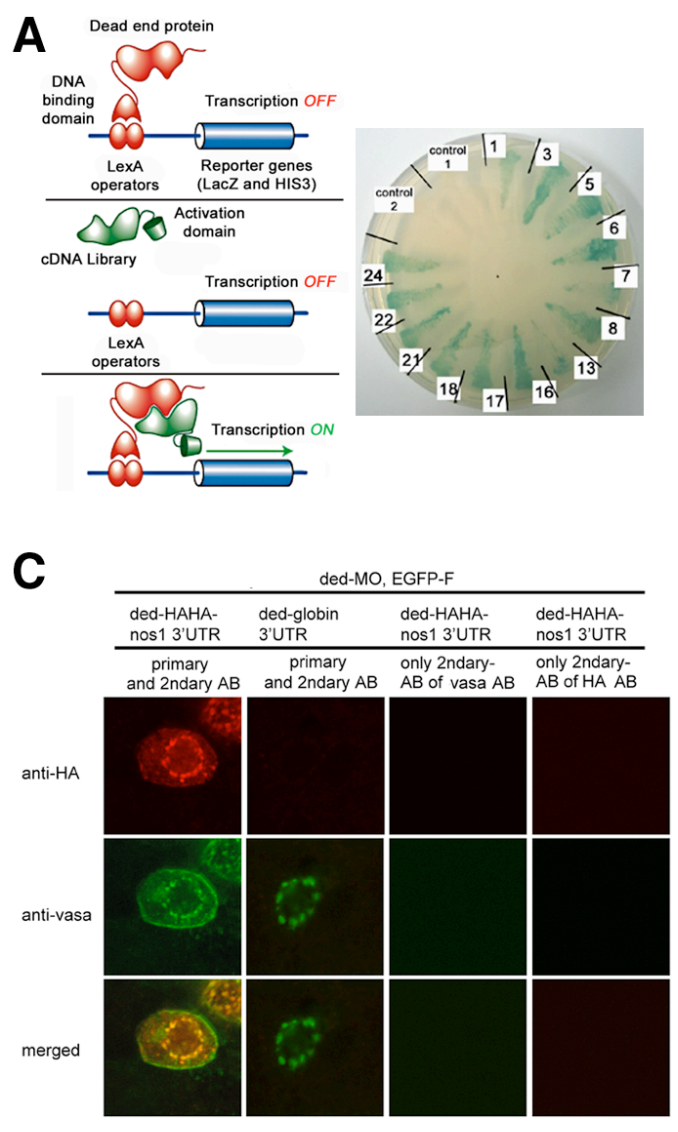

B
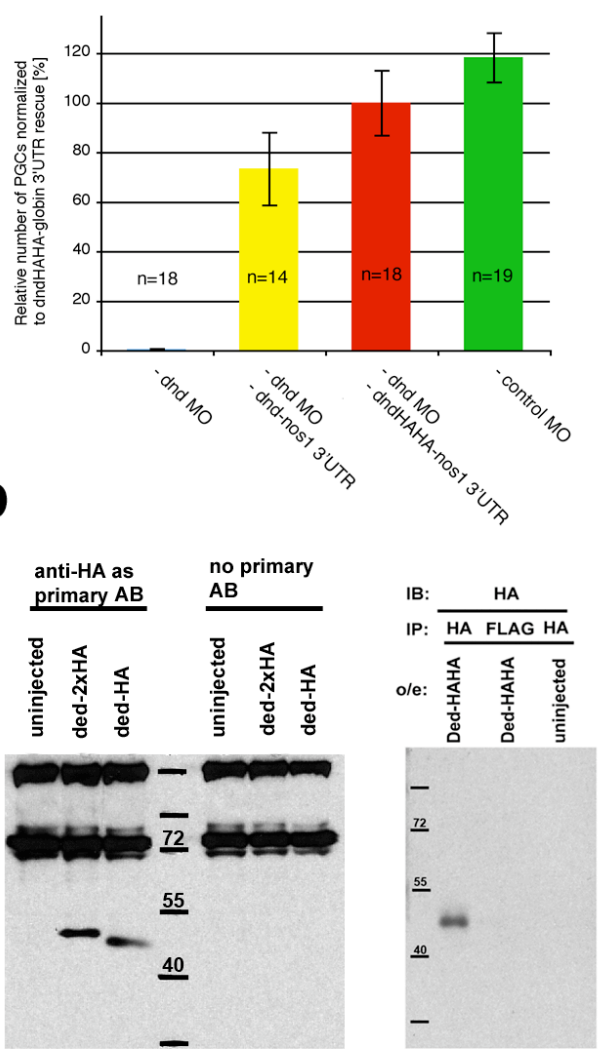

$\mathbf{E}$

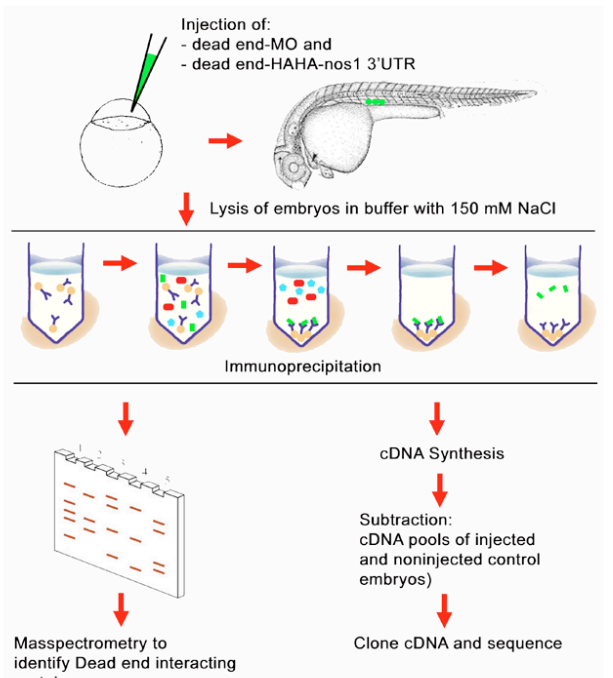

$\mathbf{F}$
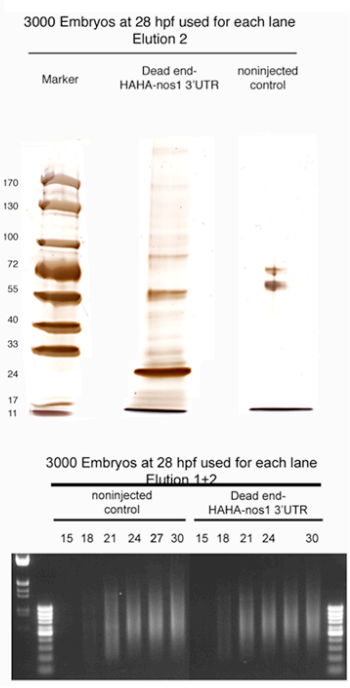

Figure 2-13: Identification of Dead end interacting proteins and RNAs by yeast-two-hybrid technology and immunoprecipitation. 
A further proof for the fact that the tagged Dead end protein normally interacts with other molecules is the fact that it assumes the proper subcellular localization. This point was demonstrated by co-injection of dead end-HAHA-nos1 3'UTR (for specific expression of the tagged dead end in the PGCs) together with EGFP-Farnesyl-nos1 3'UTR (specific expression of membrane bound EGFP in PGCs) and dnd MO (400 pg). After whole mount immunostaining of zebrafish embryos with anti-HA and antiVasa antibody, we analyzed the localization of Dead end-HAHA and Vasa. We show that Dead end-HAHA protein colocalize with Vasa in the perinuclear granules (Figure 2-13 C). Taken together, we conclude that the Dead end-HAHA protein is functional as evident by the "rescue" experiments and subcellular localization analysis and therefore Dead end-HAHA protein should still interact with partners that are critical for its function.

A pre-requisite for isolating the protein and RNA that bind the tagged Dead end is, that the Dead end-HA fusion protein expressed in zebrafish embryos is recognized by the anti-HA antibody. To check this point, we injected dnd-HAHA-nos1 3'UTR RNA or dndHA-nos1 3'UTR RNA (each at the concentration of $150 \mathrm{ng} / \mu \mathrm{l}$ ) into the one cell stage zebrafish embryo and 6 hours later transferred the embryos into loading buffer for SDS-PAGE followed by immunoblotting (Figure 2-13 D, right side). Indeed, HA-tag fused to Dead end is recognized specifically (at about $50 \mathrm{kDa}$ ) by the anti-HA antibody. Furthermore, the double HA-tagged Dead end shows higher detection sensitivity than single HA-tagged version.

To determine whether Dead end-HAHA protein can be immunoprecipitated using antiHA antibody, we injected dnd MO (1 ng) and dead end-HAHA-SV4O 3'UTR RNA (at a concentration of $150 \mathrm{ng} / \mu \mathrm{l}$ ) to knock down the endogenous Dead end and for expression of the tagged version in the whole embryo. Using 160 embryos of the stage $50-90 \%$ epiboly (6-8 hours post fertilization), Dead end-HAHA could be specifically immunoprecipitated and detected after IP and IB (Figure 2-13 D left side).

In conclusion, these results demonstrate that the double-HA-tagged version of Dead end in combination with the anti-HA antibody could serve as a system for the immunoprecipitation of Dead end interacting proteins and RNAs. Since we overexpressed Dead end-HAHA in the whole embryo for the immunoprecipitation but are interested in the co-immunoprecipitation of PGC specific factors together with Dead end-HAHA from germ cells only, we estimated to use a minimum of 3000 embryos when Dead end-HAHA is expressed in the germ cells. For the isolation of Dead end interacting factors, we injected two pools of each 3000 zebrafish embryos with dead end-HAHA-nos1 3'UTR RNA (at a concentration of $150 \mathrm{ng} / \mu \mathrm{l}$ ) together with 
dnd $\mathrm{MO}$ (1 $\mathrm{ng}$ ) to knock down endogenous Dead end and rescuing PGCs with the tagged version expressed specifically in the PGCs. As control, we used the same number of noninjected embryos, which express non-tagged Dead end. Embryos were lysed, subjected to co-immunoprecipitation and eluted with HA-peptide (Figure 2-13 E and F). One pool was used for SDS-PAGE for mass spectrometry (MS) to identify Dead end interacting proteins and several strong bands, observed after silver staining, are currently analyzed by MS (Figure 2-13 F). The second pool was used for the isolation of RNA and synthesis of amplified CDNA for the isolation of Dead end interacting RNAs (Figure 2-13 E and F). The PCR-amplified RNAs from control- and experiment-IP, will be molecularly subtracted and candidate genes will be analyzed by sequencing, in situ hybridization and knock-down experiments (Figure 2-13 E). 


\section{Discussion}

\subsection{Germ Cell Migration}

In the first part of this work, we have addressed the question of how germ cells are guided from their site of specification towards the region where the somatic part of the gonad will develop. In a large-scale antisense oligonucleotide based screen and in a forward genetic screen, we and others have shown that the chemokine SDF-1a and its receptor CXCR4b are essential and sufficient for guiding the migration of primordial germ cells from their site of specification to the region of the zebrafish gonad (Doitsidou et al., 2002; Knaut et al., 2003). To investigate the basis for germ cell guidance in other species, we have chosen to examine the function of SDF-1 in this process in the chick and mouse model systems as avian and murine/mammalian representatives. We did not make similar attempts in the fruit fly Drosophila melanogaster, which is a popular system for studying PGC migration and guidance (Coffman et al., 2002; Kunwar et al., 2003; Moore et al., 1998; Starz-Gaiano, 2002; Starz-Gaiano et al., 2001; Starz-Gaiano and Lehmann, 2001; Stein et al., 2002; Zhang et al., 1997), since chemokines and their receptors are not found in the genome of this model organism.

\subsection{The Role of the Chemokine SDF-1 in Avian Germ Cell Migration}

The migration path of PGCs in chick is remarkably similar to that taken by leukocytes during normal development and disease as well as by metastatic cells. In this study, we provide evidence that implicates SDF-1 $\alpha$ in guiding chicken germ cells as they leave the blood vessels on their way to the region of the gonad.

Ectopic expression of SDF- $1 \alpha$, but not SDF-1 $\beta$, could attract PGCs at the time at which they migrate through the endothelium but not in earlier stages. Our interpretation of these results is that SDF-1 does not play a role in PGC migration before stage $\mathrm{HH} 11$, nor is it responsible for the commonly observed early ectopic localization of PGCs in the head region (Nakamura et al., 1988), as could have been inferred from SDF-1 
expression domains at early developmental stages. We therefore favor the idea that early migration of chick PGCs, as well as the early ectopic positioning of PGCs, reflects the function of another signaling molecule or results from non-guided cell movements. As we were not able to label the PGCs simultaneously with germ cell markers and CXCR4, we could not exclude the formal possibility that the cells do not respond to SDF-1 at these stages due to lack of receptor on their cell membrane.

The proposed role for SDF-1 in migration of chick PGCs is highly reminiscent of the mechanism underlying the migration of hematopoietic precursor cells and lymphocytes as they exit the blood vessels. Here, SDF-1 stimulates integrin-mediated arrest of CD34 expressing cells (Peled et al., 1999) and mediates transendothelial migration of T lymphocytes (Phillips and Ager, 2002) possibly through rapid increase of integrin avidity (Campbell et al., 1998; Grabovsky et al., 2000).

\subsection{The Role of the Chemokine SDF-1 in Murine Germ Cell Migration}

In collaboration with other groups, we could show that in mice colonization of the gonad by germ cells and PGC survival were impaired in animals lacking functional SDF-1 or CXCR4 (Molyneaux et al., 2003) (similar findings were reported by another group (Ara et al., 2003)). Since PGCs are still migrating in the direction of the gonad of animals lacking functional SDF-1 or CXCR4 and were properly positioned in the hindgut before the stage of directed migration towards the gonads, it was proposed that SDF-1 might be complemented by other chemokines or cytokines that play a redundant role during early steps of PGC migration (Ara et al., 2003). To address this notion, we examined the expression pattern of mouse SDF-1 $\alpha$ and SDF-1 $\beta$ with respect to the position of the germ cells by in situ hybridization from developmental stages E8.5 to E11.5. At E9, before the PGCs migrate dorsally towards the point where they exit the gut, sdf-1 expression and the position of germ cells in the gonad are clearly distinct. Since these data show that most PGCs are distant from SDF-1 expression domain prior to the time point at which they migrate dorsally (E9-E9.5), we conclude that SDF-1 does not play a role in guiding the cells anteriorly along the ventral side of the hindgut. The migration of the cells to the position adjacent to the genital ridge is therefore guided by other chemokines or cytokines.

The observation that transepithelial migration of mouse PGCs occurs specifically in the 
dorsal-most part of the hindgut, where $s d f-1$ is expressed, is consistent with the suggestion that the cells are attracted towards this region. Interestingly, cells located at ventral positions never exit the hindgut despite the fact that they clearly bounce against its walls. It would be interesting to determine whether in analogy to the situation in Drosophila (Jaglarz and Howard, 1994; Jaglarz and Howard, 1995; StarzGaiano and Lehmann, 2001), only parts of the mouse hindgut epithelium become competent for transmigration due to specific alterations in epithelial morphology.

\subsection{Conservation of the mechanism of PGC guidance}

The demonstration that SDF-1/CXCR4 signaling is important for germ cell migration in birds (aves), together with similar findings in ray-finned fish (actinopterygii) and mammals (mammalia) suggest that this mechanism had evolved before the phylum Chordata diverged. Moreover, the requirement for seven transmembrane domain receptors for PGC migration could represent a more ancient mechanism since Drosophila PGCs, which transmigrate through the gut epithelium on their way to the gonad also appear to depend on the function of such proteins (Starz-Gaiano, 2002). Despite the apparent evolutionary conservation with respect to the use of the CXCR4SDF-1 signalling in PGC migration, an important difference should be pointed out. In contrast to the role of SDF-1a in fish, which is essential for PGC guidance throughout their migration (Doitsidou et al., 2002), chicken and mouse germ cells appear to perform the first phases of migration independently of SDF-1 function (Molyneaux et al., 2003) and this work). Furthermore, the function of SDF-1 in PGC migration is required for different processes in PGC development in different organisms. Whereas in zebrafish, SDF-1a is the key guidance cue that directs PGCs towards the developing gonad, germ cells in mice are initially directed by another signaling cue and depend on SDF-1 function for survival. 


\subsection{Basis and Relevance to screen for Germ Plasm Components: The Identification of dead end}

The second part of this work is focused on a better understanding of the molecular mechanism involved in germ cell specification, motility and fate maintenance by the identification of new germ plasm/germ cell components.

Despite the fact, that germ plasm was found in a wide range of species, its precise composition and biochemical function are poorly understood. Interestingly, the molecular composition of the germ plasm appears to be conserved across species as exemplified by the vasa gene whose RNA or protein serves as a universal molecular marker for the germline (Raz, 2000). Moreover, in some cases it has been demonstrated that certain germ plasm components play an analogous role in the development of PGCs in evolutionary distant organisms (e.g. the Nanos protein in Drosophila, Caenorhabditis elegans and zebrafish (Kobayashi et al., 1996; Koprunner et al., 2001; Subramaniam and Seydoux, 1999; Wang and Lehmann, 1991)). While many germ plasm components have originally been identified based on their role in PGC specification and development or their distribution in the early embryo, the same molecules appear to function also at later steps of germ cell development. For example, Vasa which is important for early PGC formation in Drosophila is also expressed during oogenesis stages where it is important for cyst development and oocyte differentiation (Hay et al., 1988; Kobayashi, 1998; Lasko and Ashburner, 1988; Styhler et al., 1998; Tomancak et al., 1998). Several molecules expressed in the germ plasm of lower organisms are known to be expressed in mammalian germline cells upon arrival at the region of the gonad and thereafter. Furthermore, these molecules are found within structures resembling germ plasm (Eddy, 1975; Noce et al., 2001). The requirement for the function of such molecules at later stages is revealed by spermatogenesis defects in mice deficient for Vasa (Tanaka et al., 2000) as well as by male fertility defects in humans deficient for DAZ, which belongs to a gene family whose members are expressed in the germ plasm of Xenopus (Houston and King, 2000b; Houston et al., 1998; Xu et al., 2001).

Thus, identification and functional analysis of additional germ plasm/germ cell components should elucidate the molecular mechanisms of early and late germline development. Such molecules could also be important for gametogenesis in mammals with relevance for infertility syndromes in humans.

To identify such molecules and analyze the molecular basis of PGC specification, motility and fate maintenance, we have benefited from a large scale in situ 
hybridization screen to identify new RNAs that are expressed specifically in PGCs. One of the genes isolated in this screen is the putative RNA binding protein Dead end. This gene is expressed in the PGCs of zebrafish during the first days of their development (Weidinger et al., 2003).

\section{6 dead end, a Germ Plasm Component is Associated with Perinuclear Granules}

In situ hybridization experiments to visualize dead end RNA show specific localization/expression of dead end RNA in the maternally provided germ plasm and in primordial germ cells (Weidinger et al., 2003). We examined the subcellular localization of Dead end protein and show that Dead end-GFP fusion protein is localized to the perinuclear granules. Hence, Dead end is localized to the same cellular structure where other zebrafish germline-specific proteins (e.g. Vasa and Nanos) are found (Knaut et al., 2000; Koprunner et al., 2001). Similar germ granules that contain multiple putative RNA binding proteins are found in germline cells of many organisms and intriguingly, in $\mathrm{C}$. elegans these structures are found in association with nuclear pores (Pitt et al., 2000). It has been proposed that germ granules regulate gene expression in PGCs posttranscriptionally, by modifying mRNA transport, stability and translation (Houston and King, 2000a; Seydoux and Strome, 1999). The existence of a putative RNA-binding domain in the Dead end protein and its localization to germ granules make it likely that $d n d$ functions in one of these processes (Weidinger et al., 2003; Youngren et al., 2005).

\subsection{Dead end and Germ Cell Specification}

To investigate if germ cell specification and/or proliferation depend on Dead end protein levels, we over-expressed dead end in zebrafish embryos. As the number of germ cells was not altered by this treatment, we conclude that an increased expression of Dead end protein is not sufficient to regulate PGC specification or proliferation. Consistently, inhibition of dead end mRNA translation (see below) did not affect PGC specification. It should be noted however that injection of morpholinos 
antisense oligonucleotides into early embryos does not interfere with the function of proteins deposited into the egg during oogenesis. Thus, it is formally possible that maternally provided Dead end protein does play a role in PGC specification.

\subsection{Dead end is Important for PGC Motility}

In most species, PGCs migrate from the site at which they are specified towards the developing gonad (Starz-Gaiano and Lehmann, 2001). Zebrafish PGCs start to migrate shortly before gastrulation and follow six distinct migration steps before arriving at the region where the gonad develops (Doitsidou et al., 2002; Weidinger et al., 1999a; Weidinger et al., 2002; Yoon et al., 1997).

To determine the role of dead end in PGC development, knock-down experiments were conducted in which the translation of the mRNA was inhibited using morpholino antisense oligonucleotides. In these experiments, it was found that in early developmental stages, dead end is essential for the active migration of PGCs, one of the earliest manifestations of PGC identity. In knock-down embryos, PGCs are not motile and are carried along with somatic cells that perform gastrulation movements.

Nevertheless, in most cases, Dead end-depleted PGCs did show some morphological features of motile cells. Specifically, while formation of lamellipodia was strongly reduced, the number of PGCs extending filopodia was less affected compared to controls (Weidinger et al., 2003) and competence to stabilize long atypical protrusion is elevated during somitogenesis. Taken together, functional Dead end is required for one of the fundamental properties of PGCs, which is their ability to migrate. To the best of our knowledge this is the first description of a gene product required for the transition of PGCs from stationary to motile cells. It will therefore be interesting to identify the proteins and RNAs with which Dead end interacts as these may provide a better understanding of the molecular basis of the control of epithelial-mesenchymal transition, motility and migratory cell behavior of germ cells per se (Dumstrei et al., 2004; Reichman-Fried et al., 2004; Thorpe et al., 2004). Importantly, the dead end knock-down phenotype is strikingly different from that described for PGCs lacking CXCR4b signaling in zebrafish (Doitsidou et al., 2002; Knaut et al., 2003). While showing severe defects in directional migration, zebrafish PGCs lacking CXCR4b are motile and exhibit active migration relative to their somatic neighbors (Doitsidou et al., 2002; Knaut et al., 2003). 


\subsection{Dead end is Essential for PGC Survival}

At low magnification, we observed that GFP expressing PGCs in which Dead end was knocked down disappeared by the end of the first day of development. To trace the fate of these PGCs, we tracked individual germ cells in live embryos and found that PGCs in Dead end knockdown embryos die after exhibiting the morphological hallmarks of apoptotic cells (Rich et al., 1999), including membrane blebbing and fractionation into small apoptotic bodies. Remarkably, a similar effect could be demonstrated when the zebrafish nanos-1 expression was knocked down (Koprunner et al., 2001) but physical or genetic interaction would have to be done to prove a functional interaction between these two genes. As PGCs in Dead end-depleted zebrafish embryos do not maintain their fate, it could be possible that these cells transdifferentiate prior to their death. We show that germ cells in dead end knock down embryos maintain the perinuclear granules, a cellular structure specific for germ cells (Knaut et al., 2000; Pitt et al., 2000), until to the time of cell fractionation. Even though germ cells start to lose the expression and stabilization of germ cell specific genes several hours before they die (Weidinger et al., 2003), this cells maintain at least partially their germ cell specific fate. Recent finding have shown that the Ter allele, which has been mapped to the mouse chromosome 18 (Asada et al., 1994) encodes for the mouse homologue of the zebrafish dead end (Youngren et al., 2005). The teratoma (Ter) mutation in laboratory mice shows germ cell deficiency in all inbred strain backgrounds that have been examined (Asada et al., 1994; Stevens and Hummel, 1957; Stevens and Little, 1954) and causes dramatically increased susceptibility to spontaneous testicular teratocarcinomas in strain 129 inbred mice (Asada et al., 1994; Noguchi and Noguchi, 1985; Stevens, 1970; Stevens, 1973; Stevens and Hummel, 1957; Stevens and Little, 1954).

Taken together, Dead end deficient germ cells lose their fate and die whereas under specific genetic background conditions, some germ cells in mice survive, and form teratocarcinomas. The strong similarities between zebrafish and mouse dead end loss of function phenotypes suggest that Dead end plays a conserved role in both species. We conclude that Dead end plays a key regulatory function essential for germ cell fate maintenance and that molecular analysis of Dead end function will contribute to the understanding of the mechanisms responsible for the unique features of these cells (Kanatsu-Shinohara et al., 2004; Matsui et al., 1992). 


\subsection{Dead end, PGCs and Zebrafish Sex Determination}

Whereas germ cells in Dead end depleted embryos undergo apoptosis at the end of the first day of development, no effect on the somatic part of the embryo could be observed. Strikingly, when these embryos were raised to adulthood, all the dead end knockdown fish turned out to be males. Moreover, morphological analysis of these adult fishes revealed that no gonadal structures are present in the animals.

This finding implicating PGCs in sexual differentiation differs from findings in other organisms such as mouse and Drosophila, where both sexual types are generated in animals lacking germ cells (Beck et al., 1998; Jongens et al., 1992). To determine whether development of females is a result of loss of Dead end function or reflects the loss of the PGCs, we set out to eliminate these cells by different means. For that purpose we have developed a novel method for targeted cell ablation in zebrafish that was applied to the PGCs. This method is based on the bicistronic protein killer bacterial system parD. Preferential expression of the toxin kid in the PGCs, while protecting somatic cells by expression of the natural antidote kis, allowed specific ablation of the PGCs. We show that embryos depleted of the germ cells with this method develop into sterile male fish similar to the findings in dead end depleted animals. Thus it is not a direct function of Dead end but rather the PGCs that are important for the development of the gonad which in turn is essential for development of female fish (this work was done in collaboration, see thesis of Krasimir Slanchev and (Slanchev et al., 2005)). 


\section{Summary \& Conclusions}

In this thesis, I studied the function of SDF-1 in germ cell migration in the chick and the mouse embryo. As in many other animals, the primordial germ cells in the avian embryo are specified in positions distinct from the positions where they differentiate into sperm and egg. Unlike in other organism however, in these embryos the PGCs use the vascular system as a vehicle to transport them to the region of the gonad where they exit the blood vessels and reach their target. We show that sdf-1 mRNA is expressed in locations where PGCs are found and towards which they migrate at the time they leave the blood vessels. Ectopically expressed chicken SDF-1 $\alpha$ led to accumulation of PGCs at those positions.

In the mouse embryo, we show that SDF-1 is expressed in locations where PGCs are found when these cells transmigrate the hindgut epithelium and migrate towards the genital ridge, but not during earlier stages. This expression based analysis as well as analysis of PGC behaviour in the mouse embryo suggests that similar to our findings in chick, SDF-1 functions during the second phase of PGC migration, but not at earlier phases.

Whereas in zebrafish, SDF-1a is essential and sufficient for the guidance of PGCs towards the developing gonad, germ cell migration in mice lacking SDF-1 function is impaired but still some cells colonize the gonad. We therefore assume, that germ cells in mice are directed by another signaling cue.

While SDF-1 signaling is important for directional migration of PGCs in zebrafish, cell motility requires the function of dead end. We show that dead end RNA resides where the germ plasm is located, becomes restricted to the germline during the first hours of development. Dead end protein is localized to the perinuclear granules. Overexpression of dead end does not alter germ cell specification and number. We demonstrate that germ cells in Dead end depleted zebrafish embryos are not motile and die by the end of the first day of development resembling cells undergoing apoptosis. Finally, we show that the expression of dead end in the germ plasm or in germ cells is conserved among different vertebrate species. Recent finding have shown that the Ter locus encodes the mouse homologue of the zebrafish dead end. Mutation in this gene causes a dramatic increase in the susceptibility to spontaneous testicular teratocarcinomas in strain 129 inbred mice and leads to germ cell death in other strains. The strong resemblence between the zebrafish and the mouse phenotypes implies that Dead end plays a conserved role in both species. 
Currently, the precise molecular function of Dead end is not known. The analysis molecules with which Dead end interacts will contribute to a deeper understanding of the function of Dead end. 


\section{Material and Methods}

\subsection{Bacteria}

E. Coli Top 10F'

E. Coli ElectroTen-Blue

E. Coli ElectroMAX DH10B

E. Coli DH5 $\alpha$
Invitrogen

Stratagene

Invitrogen

Invitrogen

\subsection{Chemicals}

All chemicals, if not noted otherwise, were purchased from the companies Applichem, Merck, Roth and SIGMA

anti-DIG antibody

anti-fluorescein antibody

DIG RNA labeling Mix

DAB Diaminobenzidine

ECL

RNA isolation

Pistil
Roche 1093274

Roche 1426338

Roche 1277073

SIGMA

ECL Western Blotting Detection

Reagent, Amersham RPN2109

Trizol, Invitrogen

Dstroy-S-16, Biozyme

\subsection{Kits}

ABC-Kit Vectastain

anti-HA Affinity Matrix

mMessage mMachine Kit

Topo-TA Cloning Kit

UltraCleanTM 15 DNA Purification Kit

QIAquick Gel extraction Kit

OmniScript Kit

SuperSMART PCR cDNA Synthesis and

Creator SMART cDNA Library Construction

FLAG Tagged Protein Immunoprecipitation Kit

Advantage HF 2 PCR Kit

Vector Laboratories

Roche

Ambion

Invitrogen

$\mathrm{MO} \mathrm{BIO}$

Quiagen

Quiagen

Clontech

SIGMA

Clontech 
QIAquick PCR purification Kit

Qiagen

QIAfilter Plasmid Mini/Midi/Maxi Kit

Qiagen

5'/3'Race system for Rapid Amplification

Invitrogen

of cDNA Ends Vers. 2.0,

\subsection{Primary and Secondary Antibodies}

\begin{tabular}{|c|c|c|c|c|c|}
\hline No & $\begin{array}{c}\text { Primary } \\
\text { antibody }\end{array}$ & Specificity & Description & Company & Assay and used dilution \\
\hline P2 & $\begin{array}{c}\text { Anti-vasa } \\
\text { K12/4 }\end{array}$ & Zebrafish Vasa & Rabbit polyclonal & $\begin{array}{c}\text { From } \\
\text { Holger Knaut }\end{array}$ & $\begin{array}{c}\text { Immunostaining } \\
1: 1500\end{array}$ \\
\hline P4 & Anti-HA & HA-tag & $\begin{array}{c}\text { Monoclonal } \\
\text { (12CA5) }\end{array}$ & Roche & WB: $1: 1000$ \\
\hline P11 & Anti-HA & HA-tag & Rat Monoclonal & Roche & $\begin{array}{c}\text { Immunostaining: } 1: 200 \\
\text { WB: } 1: 1000\end{array}$ \\
\hline P12 & Anti-FLAG & FLAG-tag & $\begin{array}{c}\text { Mouse } \\
\text { Monoclonal }\end{array}$ & Sigma & WB: $1: 1000$ \\
\hline
\end{tabular}

\begin{tabular}{|c|c|c|c|c|c|}
\hline No & $\begin{array}{l}\text { Secondary } \\
\text { antibody }\end{array}$ & Specificity & Description & Company & Assay and used dilution \\
\hline S7 & HRP & $\begin{array}{c}\text { Goat-anti-rabbit } \\
\qquad \lg G\end{array}$ & $\begin{array}{c}\text { HRP conjugated } \\
\text { Polyclonal }\end{array}$ & $\begin{array}{c}\text { Vector } \\
\text { Laboratories }\end{array}$ & WB: $1: 5000$ \\
\hline S9 & $\begin{array}{l}\text { Alexa Fluor } \\
546 \text { (orange) }\end{array}$ & $\begin{array}{c}\text { Goat-anti-mouse } \\
\lg G\end{array}$ & $\begin{array}{l}\text { Alexa } 546 \\
\text { conjugated } \\
\text { Polyclonal }\end{array}$ & $\begin{array}{c}\text { Molecular } \\
\text { probes }\end{array}$ & Immunostaining 1:200 \\
\hline $\mathrm{S} 10$ & Biotinylated & $\begin{array}{l}\text { Horse-anti-mouse } \\
\qquad \lg G\end{array}$ & $\begin{array}{c}\text { Biotin- conjugated } \\
\text { Polyclonal }\end{array}$ & $\begin{array}{c}\text { Vector } \\
\text { Laboratories }\end{array}$ & WB: 1:10'000 \\
\hline $\mathrm{S} 11$ & $\begin{array}{l}\text { Cyanine } \\
\text { (green) }\end{array}$ & $\begin{array}{c}\text { Goat-anti-rabbit } \\
\lg G\end{array}$ & $\begin{array}{c}\text { Cy2- conjugated } \\
\text { Polyclonal }\end{array}$ & $\begin{array}{c}\text { Jackson } \\
\text { Immunoresearch }\end{array}$ & Immunostaining: 1:200 \\
\hline
\end{tabular}

\subsection{DNA Constructs used in this work}

\begin{tabular}{|c|c|l|}
\hline \multicolumn{2}{|c|}{ DNA constructs produced in this work } \\
\hline Plasmid No. & Name & \multicolumn{1}{c|}{ Description } \\
\hline 651 & pSP6-nanos1-pT7 & Nanos1 without 3'UTR; for antisense probe \\
\hline 667 & pSP6-Chv-pT7 & Chicken homologe of vasa; for antisense probe \\
\hline 668 & pSP6-mStella-pT7 & Mouse Stella; for antisense probe \\
\hline 669 & pSP6-mTNAP-pT7 & $\begin{array}{l}\text { Mouse Tissue nonspecific alkaline phosphatase; for } \\
\text { antisense probe }\end{array}$ \\
\hline
\end{tabular}




\begin{tabular}{|c|c|c|}
\hline 670 & pT7-mSDF-1alpha-pSP6 & Part of mouse SDF-1alpha 3'UTR; for antisense probe \\
\hline 671 & pSP6-mSDF1beta-pT7 & Part of mouse SDF-1beta 3'UTR; for antisense probe \\
\hline 672 & pSP6-mCXCR4-pT7 & Part of mouse CXCR4; for antisense probe \\
\hline 678 & Xdead end & Xenopus dead end; for sequencing the ORF \\
\hline 693 & pCRIITopo-chCXCR4 & Chick CXCR4; for antisense probe \\
\hline 707 & CMV-chSDF1a & $\begin{array}{l}\text { Chick SDF1a in pcDNA3.1(-); for expression in cells and } \\
\text { chick embryos }\end{array}$ \\
\hline 742 & CMV-chSDF1b & $\begin{array}{l}\text { Chick SDF1b in pcDNA3.1(-); for expression in cells and } \\
\text { chick embryos }\end{array}$ \\
\hline 775 & deadend-HA-SV40 3'UTR in pCS2+ & $\begin{array}{l}\text { Dead end tagged with } \mathrm{HA} \text {; for expression in cells and } \\
\text { embryos }\end{array}$ \\
\hline 776 & $\begin{array}{l}\text { deadend-HAHA-SV40 3'UTR in } \\
\text { pCS2+ }\end{array}$ & $\begin{array}{l}\text { Dead end tagged with HAHA; for expression in cells and } \\
\text { embryos }\end{array}$ \\
\hline 777 & $\begin{array}{c}\text { deadend-FLAG-SV40 3'UTR in } \\
\text { pCS2+ }\end{array}$ & $\begin{array}{l}\text { Dead end tagged with FLAG; for expression in cells and } \\
\text { embryos }\end{array}$ \\
\hline 778 & $\begin{array}{l}\text { deadend-FLAGFLAG-SV40 3'UTR in } \\
\text { pCS2+ }\end{array}$ & $\begin{array}{l}\text { Dead end tagged with 2xFLAG; for expression in cells } \\
\text { and embryos }\end{array}$ \\
\hline 857 & deadend-HAHA-nos1 3'UTR in pCS2+ & Dead end tagged with HAHA; for expression in PGCs \\
\hline
\end{tabular}

\begin{tabular}{|c|c|c|}
\hline \multicolumn{3}{|c|}{ Other plasmids used in this work } \\
\hline Plasmid No. & Name & Description \\
\hline 40 & pCS2+ & $\begin{array}{l}\text { Expression vector for DNA driven by the simian CMV } \\
\text { IE94 enhancer/promoter and for RNA transcription from } \\
\text { SP6 (sense) or T7, T3 (antisense) }\end{array}$ \\
\hline 355 & pSP6-GFP-nos1 3'UTR & $\begin{array}{l}\text { GFP fused to nos1 3'UTR for expression of GFP in the } \\
\text { PGCs specifically }\end{array}$ \\
\hline 363 & Supergerm Red & $\begin{array}{l}\text { N-terminal Vasa protein fragment sufficient for } \\
\text { localization to germ granules fused to DsRed, RNA } \\
\text { stabilized in PGCs by nanos 3'UTR; efficiently labeling of } \\
\text { PGCs in red }\end{array}$ \\
\hline 393 & EGFP-F-globin 3'UTR & $\begin{array}{l}\text { Farnesylated GFP protein is localized to the plasma } \\
\text { membrane in mammalian- and zebrafish-cells; for } \\
\text { GFPlabelling of somatic tissue }\end{array}$ \\
\hline 487 & RN3 rescORF deadend-globin 3'UTR & $\begin{array}{l}\text { dead end ORF with Moprholino } 2 \text { binding site mutated } \\
\text { that Morpholino } 2 \text { can not bind - amino acids are not } \\
\text { changed; for rescue and o/e experiments }\end{array}$ \\
\hline 493 & pSP64 EGFP-F nos1 3'UTR & $\begin{array}{l}\text { Expression of farnesylated EGFP to label membrane- } \\
\text { localized germ cells by the nos } 1 \text { 3'UTR }\end{array}$ \\
\hline 495 & SP6 ded nos1 3'UTR & $\begin{array}{l}\text { For expression of full-length zebrafish dead end protein } \\
\text { insensitive to the dead end morpholino } 2 \text {, specifically } \\
\text { expressed in PGCs driven by the nos } 13 \text { 'UTR }\end{array}$ \\
\hline 516 & RN3 dedGFP nos1 3'UTR & $\begin{array}{l}\text { Dead end-GFP fusion protein expressed specifically in } \\
\text { PGCs by the nos } 1 \text { 3'UTR and localized in the } \\
\text { perinuclear granules. }\end{array}$ \\
\hline 640 & pSP6-SDF1a-nos1 3'UTR & For o/e of zebrafish SDF-1a in PGCs \\
\hline 652 & pT7-chickded-pSP6 & Chick homologe of dead end; for antisense probe \\
\hline 653 & pT7-chickSDF1-pSP6 & $\begin{array}{l}\text { Chick SDF-1; for antisense probe, unspecific for SDF-1a } \\
\text { or SDF-1b }\end{array}$ \\
\hline
\end{tabular}




\subsection{Equipment}

Cameras

Injector

Needle puller

PCR machines

Microscopes

Centrifuges

Spectrophotometer

Western blotting
- RT slider Spot, Diagnostic Instruments

- Leica DC 300, Leica

- RT SE Spot, Diagnostic Instruments

- PV830 Pneumatic PicoPump, World

- Precision Instruments (USA)

PN-30 Microelectrode Puller, Science

Products

- Cyclone 96, Peqlab, Erlangen

- Mastercycler Personal, Eppendorf

- Leica MZ FLIII, Leica

- Zeiss Axioplan 2, Zeiss

- Leica confocal microscope DMRXE

- Olympus SZX12

Eppendorf 5415D, Eppendorf

Eppendorf 6131, Eppendorf

- Mini-PROTEAN 3, BioRad

- Mini-Trans-Blot Cell, BioRad

\subsection{Programs, Database,}

Image processing

Microscopy

Multiple sequence alignment

Cloning

Office application

Literature

Databases
Adobe Photoshop 7.0, Adobe

- Metamorph, Universal Imaging Corp.

- Leica confocal software, Leica

Sequencher, Gene Codes Corp.

Vector NTI, Invitrogen (USA)

Microsoft

PubMed www.ncbi.nln.nih.gov

- Endnote 8.0, Thomson

- FileMaker Pro 7, FileMaker Inc. 
BLAST-programs

1/2/3D protein analysis

Multible sequence alignment

Molecular Modeling
- bl2seq

- blastn

- blastp

- tblastn

ExPASy Proteomics Server www.expasy.org

EMBL-EBI www.ebi.ac.uk/services/

clustalW

www2.ebi.ac.uk/clustalw

- AMBER7

- VMD 1.8

\subsection{Molecular Biology}

\subsubsection{Plasmid DNA Isolation from E. coli}

E. coli containing a certain plasmid were inoculated into $5 \mathrm{ml}$ (Miniprep), $50 \mathrm{ml}$ (Midiprep) or $150 \mathrm{ml}$ (Maxiprep) LB Standard Medium (1\% Bacto-Tryptone (Gibco BRL), $0.5 \%$ Bacto-Yeast Extract (Gibco BRL), $1 \% \mathrm{NaCl}$ in Millipore water) with 50 $\mu \mathrm{g} / \mathrm{ml}$ ampicillin or kanamycin, and incubated at $37^{\circ} \mathrm{C}$ shaking for 16 hours. The plasmid was extracted using Plasmid Mini, Midi or Maxi Kit (Qiagen) according to the manufacturer instruction, eluted in milipore water and the concentration was measured using a BioPhotometer (Eppendorf).

For transcription, cell transfection and chick embryo electroporation the Mini/Midi/ Maxiprep DNA was further purified by extraction with 1 volume of phenol/chloroform/ isoamylalcohol (25:24:1) once or twice, followed by 13,500 rpm centrifugation for 10 minutes. The supernatant was carefully collected and subjected twice to 1 volume of chloroform, again followed by centrifugation and supernatant collection. Then, the DNA was precipitated with 0.1 volume of $3 \mathrm{M} \mathrm{NaAc}, \mathrm{pH} 5.2$ and 2.5 volume of ethanol 100 $\%$ on ice for $30 \mathrm{~min}$ or for low amounts of DNA at $-20{ }^{\circ} \mathrm{C}$ for 15 minutes. Afterwards, the DNA was pelleted by centrifugation at $13,500 \mathrm{rpm}$ and $4{ }^{\circ} \mathrm{C}$ for 15 minutes, washed with $1 \mathrm{ml} \mathrm{70 \%} \mathrm{ethanol,} \mathrm{centrifuged} \mathrm{at} 13,500 \mathrm{rpm}$ for another 5 minutes, air dried, and dissolved in a proper volume of Millipore $\mathrm{H}_{2} \mathrm{O}$. 


\subsubsection{Total RNA Isolation from Eukaryotic Cells or Embryos}

Total RNA from cells or zebrafish embryos was isolated using Trizol as described by the manufacturer.

\subsubsection{DNA and RNA Electrophoresis and Purification from Agarose Gel}

$0.5-2 \%$ agarose gel was prepared by melting agarose (Biozym) in 1×TAE Buffer (400 $\mathrm{mM}$ Tris, $0.2 \mathrm{M}$ Acetic acid, $10 \mathrm{mM}$ EDTA, $\mathrm{pH}$ 8.0) and subsequently adding ethidium bromide to a final concentration of $0.3 \mu \mathrm{g} / \mathrm{ml}$. DNA and RNA sample were mixed with 5×DNA Loading Buffer (25\% Ficoll, 100 mM EDTA, 0.05\% Bromophenol Blue), and electrophoresis was performed under 1-7 V/cm in 1 $\times$ TAE buffer.

For DNA isolation, the DNA band was cut from the gel and DNA was isolated using the UltraCleanTM 15 DNA Purification Kit (MO BIO) or the QIAquick Gel extraction Kit as described by the manufacturers.

\subsubsection{DNA Digestion with Restriction Enzymes}

For DNA analysis, about 50-200ng DNA was digested with 3-10 U restriction enzymes at the appropriate temperature for 45-60 minutes. For DNA preparation, 1-10 $\mu \mathrm{g}$ DNA was incubated with 20-40 $U$ restriction enzymes at the appropriate temperature for at least 4 hours.

\subsubsection{Dephosphorylating and Blunting of DNA Fragment}

5 '-ends of DNA fragment dephosphorylation was performed by directly adding $1 \mu \mathrm{l}$ Alkaline Phophatase $(1 \mathrm{U} / \mu \mathrm{l}$, Roche) into the restriction enzyme digestion mixture and incubating at $37^{\circ} \mathrm{C}$ for 1 hour.

DNA polymerase I large fragment (Klenow fragment) (5U/ $\mu$ l, NEB) was used to fill-in the ends of 5'-overhang DNA fragment. DNA in restriction enzyme NEBuffer supplemented with $33 \mu \mathrm{M}$ dNTPs was incubated with Klenow at a concentration of $1 \mathrm{U}$ per $\mu \mathrm{g}$ DNA at $25^{\circ} \mathrm{C}$ for 30 minutes.

$3^{\prime}$ '-overhang DNA fragment was blunted using T4 DNA Polymerase (5U/ul, Roche) in the restriction enzyme NEBuffer supplemented with $50 \mu \mathrm{M}$ dNTPs. 


\subsubsection{Ligation}

25-100 ng purified vector fragment was mixed with 3-10 folds (molecular ratio) of purified insert fragment, $1 \mu \mathrm{l}$ 10× T4 DNA ligase buffer (MBI Fermentas), and $1 \mu \mathrm{I}$ T4 DNA ligase ( $3 \mathrm{U} / \mu \mathrm{l}, \mathrm{MBI}$ Fermentas) in a total volume of $10 \mu \mathrm{l}$. This ligation mixture was incubated at RT for at least 2 hours or overnight at $16{ }^{\circ} \mathrm{C}$.

Alternatively, insert of e.g. PCR fragments were cloned by TOPO cloning according to the standard protocol of the Topo-TA Cloning Kit (Invitrogen) and PCR II, PCR 2.1 and PCR 4 vectors were used.

\subsubsection{Standard PCRs}

For standard PCR, primers were designed with 15-24 nucleotides and a melting temperature (TM) between $50{ }^{\circ} \mathrm{C}$ and $68^{\circ} \mathrm{C}$. The reaction mixture contains $1 \mu \mathrm{l}$ template DNA (10pg-100ng DNA), $2.5 \mu \mathrm{l}$ of forward primer $(5 \mathrm{mM}), 2.5 \mu \mathrm{l}$ of reverse primer (5mM), $2.5 \mu \mathrm{l}$ 10× Amersham PCR Buffer, $2.5 \mu \mathrm{l} 2.5 \mathrm{mM}$ dNTPs, and $1 \mu \mathrm{l} \mathrm{Tag}$ Polymerase $(5 \mathrm{U} / \mu \mathrm{l})$ in a total volume of $25 \mu \mathrm{l}$.

The thermocycling program (Table 5-1) was carried out as described below.

\begin{tabular}{|l|l|l|}
\hline \multicolumn{1}{l}{ Step } & \multicolumn{1}{l|}{ Temperature } & \multicolumn{1}{l|}{ Duration } \\
\hline 1. Initial Denaturation & $92^{\circ} \mathrm{C}$ & 1 minute \\
\hline 2. Denaturation & $92^{\circ} \mathrm{C}$ & 15 seconds \\
\hline 3. Annealing & $\mathrm{T}_{\mathrm{M}}-4{ }^{\circ} \mathrm{C}$ & 20 seconds \\
\hline 4. Annealing and Elongation & $72{ }^{\circ} \mathrm{C}$ & 1 minute/kb \\
\hline 5. Go to Step 2, $15-30$ cycles & $72{ }^{\circ} \mathrm{C}$ & $3-15$ minutes \\
\hline 6. Final Elongation &
\end{tabular}

Table 5-1: The thermocycling program for standard PCR.

\subsubsection{High Fidelity PCRs}

The Advantage HF 2 PCR Kit (Clontech) was used for high fidelity PCR and PCRs starting from low amount of template DNA according to manufactures instruction.

\subsubsection{Amplification of 5' and 3' End of cDNAs}

To amplify 5' and 3' ends of cDNAs the 5'/3'Race system for Rapid Amplification of cDNA Ends Vers. 2.0 (Invitrogen) was used according to manufactures instructions. 


\subsubsection{Standard Reverse Transcription}

The OmniScript Kit (Qiagen) was used to reverse transcribe RNA to cDNA. The reaction mixture contains $5 \mathrm{ng}$ to $2 \mu \mathrm{g}$ template RNA, $2 \mu$ l Oligo-dT-primer $(10 \mu \mathrm{M}), 2 \mu \mathrm{l}$

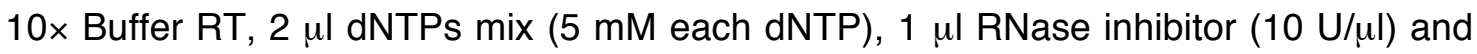
$1 \mu \mathrm{l}$ Omniscript reverse transcriptase in a total volume of $20 \mu \mathrm{l}$. Reaction mixture was incubated for 60 minutes at $37^{\circ} \mathrm{C}$.

\subsubsection{PGC specific full length cDNA library synthesis}

To synthesis a zebrafish PGC specific full-length cDNA library, 635 single germ cells from the stage 10 somite $-24 \mathrm{hpf}$ were isolated according to the procedure in Table 5-2.

1. Injection of fish in the evening with $80-120 \mathrm{ng} / \mathrm{ml} 355$ (GFP-nos1 3'UTR) to label PGCs with GFP

Incubation of embryos until stage 10 somite $-24 \mathrm{hpf}$

2. Embed the tube of a syringe into dry ice within a polystyrol box and place a 1.5 $\mathrm{ml}$ tube into the tube to collect the isolated cell in a frozen drops of TM1 buffer (100mM NaCl, 5mM KCL, 5mM Hepes, 1\%PEG 20000, pH 7.0, 0.2 micron filtered) or RNAlater (Qiagen).

3. Pump with the installed syringe mineral oil (SIGMA M-5904) through the "Transplantation-Manual injector" tube system to remove air bubbles, cut a glass needle and install it into the "TM injector"

4. Choose under the binocular 5 - 7 embryos with good-labelled PGCs in the right position in the embryo and dechorionate them.

5. Transfer embryos with a $200 \mathrm{ml}$ pipette-tip into a $10 \mathrm{~cm}$ diameter glass petridish with about $450 \mathrm{ml}$ TM1 buffer in the middle. Pipet up and down "the embryos" (keep pipet rectangular) and check from time to time under the binocular if cells are dissociated well. Let cells settle down for about $5 \mathrm{~min}$.

6. Search via GFP under the binocular the germ cells, bring needle with the micromanipulator to the germ cell and suck it with the Transplantation-Manual injector.

7. Transfer cell into a 1-2 $\mathrm{ml}$ drop (TM1 buffer or RNAlater), which is placed onto a coated glass slide (SIGMAcoate). 
8. Place glass slide into dry ice filled polystyrol box and scratch with a scalpel-tip the ice drop containing the cell into the e-cup.

9. Store cells at $-80^{\circ} \mathrm{C}$ until RNA isolation with Trizol will be done.

Table 5-2: Single PGC isolation.

RNA of isolated PGCs was than purified and isolated according to the manufactures instruction with Trizol (Invitrogen) with modifications as described below (Table 5-3).

1. Add 10 times Trizol (Invitrogen) to the original volume of the sample. Vortex thoroughly.

2. Incubate the homogenized samples for 5 minutes at RT.

3. Add $0.2 \mathrm{ml}$ of chloroform per $1 \mathrm{ml}$ of Trizol Reagent.

4. Shake tubes vigorously by hand for 15 seconds and incubate them at RT for 2 to 3 minutes.

5. Centrifuge the samples at maximum speed for 15 minutes at $4^{\circ} \mathrm{C}$.

6. Following centrifugation, the mixture separates into a lower red, phenolchloroform phase, an interphase, and a colorless upper aqueous phase. RNA remains exclusively in the aqueous phase. The volume of the aqueous phase is about $60 \%$ of the volume of Trizol Reagent used for homogenization.

7. Transfer the aqueous phase to a fresh $1.5 \mathrm{ml}$ tube. Add $7.5 \mathrm{ug}(=0.5 \mathrm{ml})$ glycogen and add 0.8 volume of isopropanol to each tube.

8. Incubate samples over night at $-20^{\circ} \mathrm{C}$.

9. Centrifuge at maximum for 15 minutes at $4{ }^{\circ} \mathrm{C}$. (The RNA precipitate, often invisible before centrifugation, forms a gel-like pellet on the side and bottom of the tube.)

10. Remove the supernatant. Wash the RNA pellet with $80 \%$ ethanol, adding $1 \mathrm{ml}$ of $80 \%$ ethanol to the tube. Mix the sample by vortexing and centrifuge at maximum speed for 10 minutes at $4^{\circ} \mathrm{C}$.

11. Remove with a thin pipette all remaining liquid and air-dry the RNA pellet for 5 min. Dissolve RNA in RNase-free water.

Table 5-3: RNA isolation from less than 1000 germ cells with Trizol.

For reverse transcription, PCR amplification and subsequent directional cloning of full length cDNA into pDNR-LIB vector (Clontech), a combination of SuperSMART PCR 
cDNA Synthesis Kit and Creator SMART cDNA Library Construction Kit (Clontech) was used as described by the manufacturers. For the reverse transcription and cDNA amplification, primer from Creator SMART cDNA Library Construction Kit only were used.

\subsubsection{Yeast-two-hybrid screen}

In collaboration with the Dualsystems Biotech AG (Zurich) Zebrafish PGC specific fulllength cDNA library from the stage of 10 somite $-24 \mathrm{hpf}$ was subcloned into bait vector pGAD-DS and yeast-two-hybrid screen was performed according to their standard procedure.

\subsubsection{Preparation of Electrocompetent E. coli Cells and Transformation by Electroporation}

Preparation of electrocompetent E.coli cells was performed as described below (Table $5-4)$

1. Inoculate two single colonies of $E$. coli into $2 \times 10 \mathrm{ml}$ LB medium and cultured at

$37^{\circ} \mathrm{C}$ shaking overnight (250 rpm).

2. Inoculate the $2 \times 10 \mathrm{ml}$ overnight cultures into $2 \times 1$ liter prewarmed LB medium and culture them at $37^{\circ} \mathrm{C}$ shaking until the O.D.600 reached $0.6-0.8$ (about 3 hours).

3. Chill the cells on ice for 10-30 minutes.

4. Centrifuge at $5,000 \mathrm{rpm}$ at $4{ }^{\circ} \mathrm{C}$ for 20 minutes to harvest the cells.

5. Discard the supernatant, wash each pellet from 1 liter culture with 1 liter prechilled water (1:1 wash), then centrifuge at $5,000 \mathrm{rpm}$ at $4{ }^{\circ} \mathrm{C}$ for 20 minutes.

6. Discard the supernatant, wash each pellet with $100 \mathrm{ml}$ prechilled $10 \%$ glycerol (1:10 wash), then centrifuge at $6,000 \mathrm{rpm}$ (Sorvall $\mathrm{HS}-4$ rotor) at $4{ }^{\circ} \mathrm{C}$ for 10 minutes.

7. Discard the supernatant, wash each pellet with $20 \mathrm{ml}$ prechilled $10 \%$ glycerol (1:50 wash), then centrifuge at $6,000 \mathrm{rpm}$ at $4{ }^{\circ} \mathrm{C}$ for 10 minutes.

8. Discard the supernatant, wash each pellet with $2 \mathrm{ml}$ prechilled $10 \%$ glycerol (1:500 wash), then centrifuge at $6,000 \mathrm{rpm}$ at $4{ }^{\circ} \mathrm{C}$ for 5 minutes.

9. Aspirate the supernatant, resuspend each pellet in 2-3 $\mathrm{ml} \mathrm{10 \%} \mathrm{glycerol.} 40 \mu \mathrm{l}$ or 
$80 \mu \mathrm{l}$ resuspension was aliquoted into each tube on ice, frozen in liquid nitrogen, and stored at $-80^{\circ} \mathrm{C}$.

Table 5-4: Preparation of electrocompetent E. coli cells.

$50 \mu \mathrm{l}$ competent cells were thawed on ice and transferred into a prechilled $0.1 \mathrm{~cm}$ electrode Gene Pulser Cuvette (Bio-Rad). 1-5 $\mu$ l DNA solution (1-100 ng/ $\mu \mathrm{l}$ ) or 1-5 $\mu \mathrm{l}$ ligation product was added directly into the competent cells and mixed well by gently flicking. Then, the surface of the cuvette was completely dried and the electroporation was performed using Gene Pulser (Bio-Rad) under the condition of $1.8 \mathrm{kV}, 200 \Omega$ resistance, $25 \mu \mathrm{F}$ capacitance. Afterwards, $960 \mu \mathrm{l}$ prewarmed LB medium was immediately supplied to the electroporated $E$. coli for recovery. The cells were recovered at $37{ }^{\circ} \mathrm{C}$ rotating for 1 hour, followed by plating $100 \mu \mathrm{l}$ and $900 \mu \mathrm{l}$ on separate selective plates.

\subsection{Biochemistry}

\subsubsection{Immunoprecipitation (IP)}

Lysis buffer (50 mM Tris $\mathrm{HCl}$ pH 7.5, 150-200 mM NaCl , 1 mM EDTA, 1 mM EGTA (Sigma), $10 \%$ Glycerol , $1 \%$ Triton X-100) in RNAse free water was autoclaved and before use supplemented with $1 \mathrm{mM} \mathrm{MgCl} 2,50 \mathrm{U} / \mathrm{ml}$ Rnasin, Roche "complete mini" Protease inhibitor tablet with EDTA (1 tablet per $10 \mathrm{ml}$ lysis buffer), $1.6 \mathrm{mM}$ vanadyl ribonucleosid complex (Sigma) and $100 \mu \mathrm{g} / \mathrm{ml}$ PMSF (Sigma).

It is recommended to use $10^{6}-10^{7}$ cells $/ \mathrm{ml}$ of lysis buffer, which equals to $100-1000$ $80 \%$ epiboly embryos $/ \mathrm{ml}$ lysis buffer. For IP of $50-90 \%$ epiboly embryos, 160 embryos/ml lysis buffer were used and for IP of $28 \mathrm{hpf}$ embryos, 500-1500 embryos $/ \mathrm{ml}$ lysis buffer were used. Embryo lysate was prepared according to Table 5-5

\section{Embryo Preparation for 28 hpf Embryo Lysis}

1. Injection zebrafish embryo at the one cell stage

2. Grow embryos up to $28 \mathrm{hpf}$

3. Dechorionate with forceps

4. Transfer embryos into $50 \mathrm{ml}$ Falcon tube and count them (all done in Danieaus

- see chapter "Fish breeding and incubation") 


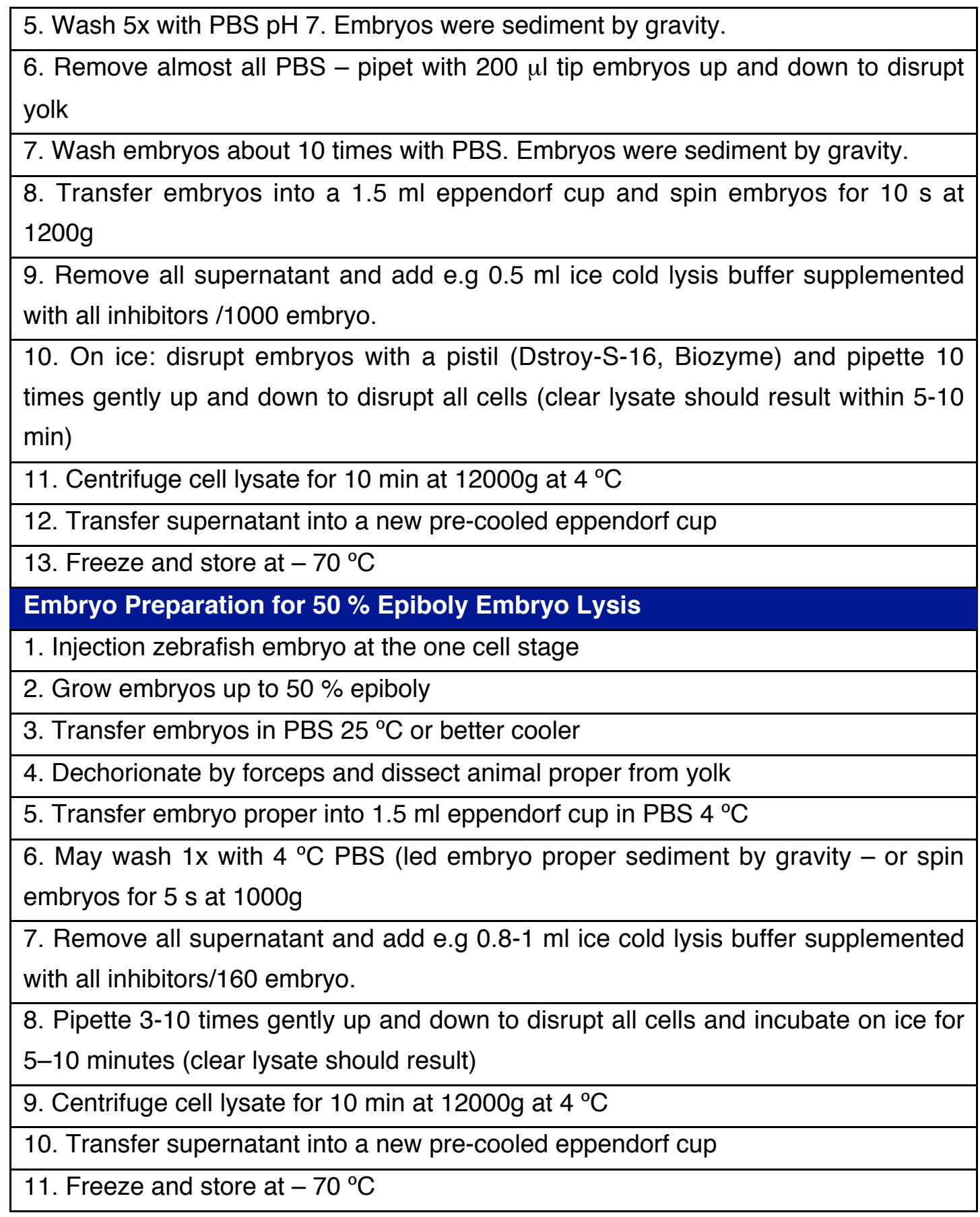

Table 5-5: Preparation of embryo lysate for immunoprecipitation

For immunoprecipitation, 50 to $100 \mu$ l beads with precoupled FLAG- or HA-antibody (FLAG Tagged Protein Immunoprecipitation Kit (SIGMA) and anti-HA affinity matrix (Roche) were used as following (Table 5-6). 
All the work was done at $4^{\circ} \mathrm{C}$

1. Resin were washed 6 times with $1.5 \mathrm{ml}$ lysis buffer (spined at 10 '600 $\mathrm{g}$ for 5 seconds).

2. $0.8-1 \mathrm{ml}$ of lysate $/ 1.5 \mathrm{ml}$ tube were added to the beads and tagged protein were immunoprecipitated for 4-6 hours in a rotator.

3. Wash beads with lysis buffer with $200 \mathrm{mM} \mathrm{NaCl}$ : 2x 5 minutes, $2 x 10$ minutes and $1 \times 15$ minutes.

4. Elution 3x 20 min with 40-80 $\mu$ l FLAG-peptide (150 $\mathrm{ng} / \mu \mathrm{l}$ ) or HA-peptide (300 $\mathrm{ng} / \mu \mathrm{l})$ dissolved in lysis buffer with $200 \mathrm{mM} \mathrm{NaCl}$.

5. $37.5 \mu \mathrm{l}$ of elute were mixed with $12.5 \mu \mathrm{l} 4 \mathrm{x}$ loading buffer, boiled at $95^{\circ} \mathrm{C}$ for 5 minutes, cooled down and loaded on an SDS-PAGE gel.

Table 5-6: Procedure of immunoprecipitation.

\subsubsection{Protein Gel Electrophoresis}

SDS-polyacrylamide gels (SDS-PAGE) were prepared with protein gel preparation system (Bio-Rad). 12\% separating gel and 6\% stacking gel (Tab. X-x) were applied to detect proteins smaller than $50 \mathrm{kDa}$, while $10 \%$ separating gel and $5 \%$ stacking gel (Tab. X-x) were used to analyze proteins larger than $50 \mathrm{kDa}$. A protein sample (e.g. 0.6 zebrafish embryos/ $\mu$ l loading buffer) was mixed with the same volume of $2 \times S D S$ loading buffer (125 mM Tris, $\mathrm{pH} 6.8,20 \%$ glycerol, $0.02 \%$ bromophenol blue, $2 \% \beta$ mercaptoethanol, $4 \%$ SDS), and heated at $95{ }^{\circ} \mathrm{C}$ for 5 minutes or in boiling water for 3 minutes. A maximum of $25-50 \mu \mathrm{l}$ sample were loaded into the slot, empty slots were filled with the same amount of loading buffer only and electrophoresis was performed in $1 \times$ SDS buffer (25 mM Tris-base, $0.1 \%$ SDS, $192 \mathrm{mM}$ glycine, $\mathrm{pH} 8.75$ ) under 20 $\mathrm{mA} / \mathrm{gel}$, following 10-20 minutes preelectrophoresis under the same condition.

\begin{tabular}{|l|l|l|}
\hline Separating Gel & $10 \%$ & $12 \%$ \\
\hline $1.5 \mathrm{M}$ Tris, pH 8.8 & $7.5 \mathrm{ml}$ & $6 \mathrm{ml}$ \\
\hline $\begin{array}{l}30 \% \text { Acrylamide-Bisacrylamide Solution } \\
\text { (Roth) }\end{array}$ & $10 \mathrm{ml}$ & $10 \mathrm{ml}$ \\
\hline $\mathrm{H}_{2} \mathrm{O}$ & $12 \mathrm{ml}$ & $7.6 \mathrm{ml}$ \\
\hline $10 \%$ SDS & $300 \mu \mathrm{l}$ & $240 \mu \mathrm{l}$ \\
\hline $10 \%$ APS & $150 \mu \mathrm{l}$ & $120 \mu \mathrm{l}$ \\
\hline
\end{tabular}




\begin{tabular}{|l|l|l|}
\hline TEMED & $15 \mu \mathrm{l}$ & $12 \mu \mathrm{l}$ \\
\hline Total Volume & $\mathbf{3 0} \mathbf{~ m l}$ & $\mathbf{2 4} \mathbf{~ m l}$ \\
\hline
\end{tabular}

\begin{tabular}{|l|l|l|}
\hline \multicolumn{2}{l}{ Stacking Gel } & \multicolumn{2}{l}{$\mathbf{6 \%}$} \\
\hline $1 \mathrm{M}$ Tris, $\mathrm{pH} 6.8$ & $3 \mathrm{ml}$ & $2.5 \mathrm{ml}$ \\
\hline $\begin{array}{l}30 \% \text { Acrylamide-Bisacrylamide Solution } \\
\text { (Roth) }\end{array}$ & $2 \mathrm{ml}$ & $2 \mathrm{ml}$ \\
\hline $\mathrm{H}_{2} \mathrm{O}$ & $6.82 \mathrm{ml}$ & $5.35 \mathrm{ml}$ \\
\hline $10 \%$ SDS & $120 \mu \mathrm{l}$ & $100 \mu \mathrm{l}$ \\
\hline $10 \%$ APS & $60 \mu \mathrm{l}$ & $50 \mu \mathrm{l}$ \\
\hline TEMED & $12 \mu \mathrm{l}$ & $10 \mu \mathrm{l}$ \\
\hline Total Volume & $\mathbf{1 2} \mathbf{~} \mathbf{l}$ & $\mathbf{1 0} \mathbf{~} \mathbf{l}$ \\
\hline
\end{tabular}

Table 5-7: The components of SDS-polyacrylamide gels.

\subsubsection{Coomassie Blue Staining}

After gel electrophoresis, for commassie blue staining, the stacking gel was removed from the resolving gel, which was stained with Coomassie blue staining solution (0.25\% Coomassie brilliant blue R 250, 45\% methanol, $10 \%$ acetic acid) at RT for 0.5 1 hour. The Coomassie stained gel was rinsed twice with water and subsequently destained in destain buffer (5\% methanol, $10 \%$ acetic acid) for several hours to overnight.

\subsubsection{Silver Staining for Mass Spectrometry}

Silver staining for mass spectrometry was performed as described below (Table 5-8). All reagents have pro analysis purity.

\begin{tabular}{|c|c|c|c|}
\hline Treatment & & Solution & Duration \\
\hline Fixation & 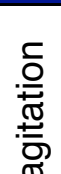 & $\begin{array}{l}50 \%(v / v) \text { Ethanol } \\
12 \% \text { acetic acid } \\
0.05 \%(v / v) \text { of } 37 \% \text { formaldehyd }\end{array}$ & $\begin{array}{l}90 \text { minutes to } \\
\text { overnight }\end{array}$ \\
\hline $3 x$ Wash & 3 & in $50 \%$ ethanol in $\mathrm{H}_{2} \mathrm{O}$ & 20 minutes each \\
\hline Impregnation & & $0,01 \%(w / v) \mathrm{Na}_{2} \mathrm{~S}_{2} \mathrm{O}_{3} \times 5 \mathrm{H}_{2} \mathrm{O}$ in $\mathrm{H}_{2} \mathrm{O}$ & 1 minute exact!! \\
\hline
\end{tabular}




\begin{tabular}{|c|c|c|}
\hline 3x Wash & $\mathrm{H}_{2} \mathrm{O}$ & $\begin{array}{l}20 \text { seconds } \\
\text { exact!! }\end{array}$ \\
\hline Colorization & $\begin{array}{l}0.1 \%(\mathrm{w} / \mathrm{v}) \mathrm{AgNO}_{3} \\
0.075 \%(\mathrm{v} / \mathrm{v}) \text { of } 37 \% \text { formaldehyd }\end{array}$ & $20 \mathrm{~min}$ \\
\hline 3x Wash & $\mathrm{H}_{2} \mathrm{O}$ & $\begin{array}{l}20 \text { seconds } \\
\text { exact!! }\end{array}$ \\
\hline Development & $\begin{array}{l}3 \%(\mathrm{w} / \mathrm{v}) \mathrm{Na}_{2} \mathrm{CO}_{3}, 0,05 \%(\mathrm{v} / \mathrm{v}) \text { of } \\
37 \% \text { formaldehyd, } 2 \times 10^{-4} \%(\mathrm{w} / \mathrm{v}) \\
\mathrm{Na}_{2} \mathrm{~S}_{2} \mathrm{O}_{3} \times 5 \mathrm{H}_{2} \mathrm{O} \text { in } \mathrm{H}_{2} \mathrm{O}\end{array}$ & $2-10$ minutes \\
\hline Stop & $10 \mathrm{mM} \mathrm{Na} \mathrm{EDDTA}_{2}$ & 10 minutes \\
\hline Storage & $\mathrm{H}_{2} \mathrm{O}$ for HPLC & days to weeks \\
\hline
\end{tabular}

Table 5-8: Silver staining for mass spectrometry

\subsubsection{Western Blotting}

Western blotting and subsequent immunostaining were performed as described below (Table 5-9) using antibodies against HA-tag, FLAG-tag, Dead end, Nanos and Vasa.

1. Cut a Protran Nitrocellulose Transfer Membrane (Schleicher \& Schell BioScience) into a similar size than the gel and 4 pieces of Whatman paper the slightly larger than the gel and presock them in blot buffer $(25 \mathrm{mM}$ Tris-base -3 $\mathrm{g} / \mathrm{l}, 192 \mathrm{mM}$ glycine $-14.4 \mathrm{~g} / \mathrm{l}, 20 \%$ methanol).

2. Between two double-layered presocked Whatman paper, the SDSpolyacrylamide gel was placed tightly onto a presocked nitrocellulose membrane avoiding any air bubble in between, with the membrane close to the anode and the gel close to the cathode.

3. Press this sandwich including Whatman paper, gel, and membrane tightly together into a clamp. Electroblot was performed in blot buffer using western blotting system (Bio-Rad) at $15 \mathrm{~V}$ overnight or at $100 \mathrm{~V}$ for 1 hours with a cooling chamber.

4. Stop the membrane transfer, and stain for 1-3 min the membrane with Ponceau S staining solution( $0.2 \%$ Ponceau S, $3 \%$ trichlor acetic acid, $3 \%$ sulfosalicylic acid) to check the membrane transfer efficiency.

5. Destain the Ponceau $\mathrm{S}$ with water and then TBST buffer $(20 \mathrm{mM}$ Tris, $\mathrm{pH} 7.6$, 
$0.8 \% \mathrm{NaCl}, 0.05 \%$ Tween 20 ).

6. Block the membrane in blocking solution (1-5\% low fat milk powder in TBST) at RT for 1 hour, rocking on a rocky machine (Biometra).

7. Dilute the primary antibody 1:100-1:1000 in blocking solution, and incubate at 4 ${ }^{\circ} \mathrm{C}$ shaking overnight (preferred) or at RT rocking for 1-2 hours.

8. Wash with TBST at RT rocking for 15 minutes.

9. Wash with TBST at RT rocking for 10 minutes.

10. Wash with TBST at RT rocking for 10 minutes..

11A. Incubate the membrane with 1:10'000 diluted biotinylated anti-rabbit, -anti-rat or -anti-mouse IgG secondary antibody in blocking solution at RT rocking for 1 hour.

12. Wash with TBST at RT rocking for $1 \times 15$ minutes, $1 \times 30$ minutes, $3 \times 10$ minutes 13. Prepare Vectastain Elite ABC Kit (Vector Laboratories) solutions to enhance the signal by forming a macromolecular complex of biotin-avidin-biotinylated horse radish peroxidase: Mix $10 \mu \mathrm{l} \mathrm{A}$ and $10 \mu \mathrm{lB}$ in $1 \mathrm{ml}$ TBST and incubate this mixture $30 \mathrm{~min}$ on a shaker. Dilute this $1 \mathrm{ml}$ with $50 \mathrm{ml}$ TBST and incubate the membrane in this final solution for $30 \mathrm{~min}$

14. Wash with TBST at RT rocking for $1 \times 15$ minutes, $4 \times 5$ minutes

15. Detection of horse radish peroxidase with ECL Western blotting detection reagents (Amersham): Mix $500 \mu$ l Solution 1 and $500 \mu$ l Solution 2 containing the chemiluminescent substrate for the HRP. The TBST-washed membranes were drained from the excess buffer and placed on Saran Wrap - protein side up. The detection reagent was equally distributed to the protein side of the membrane, incubated for 1 minute at room temperature, drained from the detection reagent and placed on fresh Saran Wrap. The blots were placed in a film cassette, and the protein side was exposed for the required time (30 sec to $30 \mathrm{~min}$ ) to a Kodak photo film which was subsequently developed according to standard procedure.

11B. When Horseradish Peroxidase (HRP) conjugated secondary antibody was used (1:10000) and the membrane incubated at RT rocking for 1 hour, washing steps 8.-10. were done followed by the detection (step 15.)

Table 5-9: Western blotting onto nitrocellulose membranes and subsequent immunostaining 


\subsection{Cell Biology}

\subsubsection{Cell Culture Medium}

Cos-7 cells were cultured at $37{ }^{\circ} \mathrm{C}$ in DMEM high glucose medium containing 4.5 $\mathrm{mg} / \mathrm{ml}$ glucose and supplemented with $10 \% \mathrm{FCS}, 100 \mathrm{U} / \mathrm{ml}$ penicillin $\mathrm{G}, 100 \mu \mathrm{g} / \mathrm{ml}$ Streptomycin.

\subsubsection{Cell Revival}

Cells from liquid nitrogen are revived in a $37^{\circ} \mathrm{C}$ water bath as quickly as possible, then transferred into a $15 \mathrm{ml}$ Falcon tube containing $5 \mathrm{ml}$ proper culture medium, and centrifuged at 1,000 rpm for 5 minutes. The supernatant medium was aspirated, $5 \mathrm{ml}$ fresh medium was added to the cell pellet and pipetted up and down for at least 15 times to break cell aggregates. The, the cell resuspension was distributed in a $10 \mathrm{~cm}$ petridish containing $5 \mathrm{ml}$ culture medium (10 $\mathrm{ml}$ in total). The dish was gently shaken left-right and backward-forward to achieve equally distribution of cells. Then, the cells were cultured in a BBD 6220 incubator (Heraeus) at $37{ }^{\circ} \mathrm{C}$ under $5 \% \mathrm{CO}_{2}$ concentration.

\subsubsection{Cell Passage and Freeze}

The medium of cultured $70-95 \%$ confluent cells in a $10 \mathrm{~cm}$ dish was aspirated. Cells were washed with $10 \mathrm{ml}$ PBS, which was then aspirated from the dish. $3 \mathrm{ml} 1 \times$ TrypsinEDTA solution (Gibco BRL) was equally distributed onto the washed cells, and incubatd at $37{ }^{\circ} \mathrm{C}$ for about 2 minutes. The dish was shaken until all the cells became floating. $11 \mathrm{ml}$ culture medium with $10 \%$ FCS was added to stop the trypsin digestion, pipetted up and down for several times to blow the cells, and then transferred into a 15 $\mathrm{ml}$ Falcon tube. Centrifugation was carried out at 1,000 rpm for 5 minutes to pellet the cells, followed by aspirating the supernatant.

For passage, the cell pellet was resuspended in $12 \mathrm{ml}$ culture medium by pipetting 15 to 20 times to break cell aggregates. $3 \mathrm{ml}$ resuspension was finally equally distributed into a $10 \mathrm{~cm}$ dish containing $9 \mathrm{ml}$ medium (1:4 dilution), gently shaken and incubated. For freeze, the cell pellet was resuspended in $2 \mathrm{ml}$ culture medium, and every $500 \mu \mathrm{l}$ cell resuspension was transferred into a cryotube (Nunc) containing $500 \mu$ l culture medium and $10 \%$ DMSO, mixed well by inverting, and sequentially frozen at $-20{ }^{\circ} \mathrm{C}$ overnight, at $-80^{\circ} \mathrm{C}$ for a week to a month, and finally in liquid nitrogen. 


\subsubsection{Cell Transfections with Plasmids}

The cultured cells were transfected with plasmids using Lipofectamine 2000 transfection reagent (Invitrogen) (Table 5-10).

1. The day before transfection, trypsinize and count the cells, plating them so that they are $90-95 \%$ confluent on the day of transfection. Cells are plated in $12 \mathrm{ml}$ of their normal growth medium containing serum and without antibiotics. Best results are obtained when cells are transfected at a high cell density.

2. For each well (10 cm diameter petridish) of cells to be transfected, dilute 19.2 $\mu \mathrm{g}$ of DNA into $1.2 \mathrm{ml}$ of DMEM without serum.

3. For each well of cells, dilute $72 \mu \mathrm{l}$ of LIPOFECTAMINE 2000 (LF2000 $^{\mathrm{TM}}$ ) Reagent into $1.2 \mathrm{ml}$ of DMEM without serum and incubate for $5 \mathrm{~min}$ at room temperature. Once the LF2000 Reagent is diluted, combine it with the DNA within 5 min. Longer incubation times may result in decreased activity. This dilution can be prepared in bulk for multiple wells.

4. Combine the diluted DNA (from step 2) with the diluted LF2000 Reagent (from step 3); Volume total $2.4 \mathrm{ml}$. Incubate at room temperature for $20 \mathrm{~min}$ to allow DNA-LF2000 Reagent complexes to form.

5. Remove growth medium from cells, wash them once with medium and add 12 $\mathrm{ml}$ of medium without serum to each well. Add the DNA-LF2000 Reagent complexes $(2.4 \mathrm{ml})$ directly to each well and mix gently by rocking the plate back and forth.

6. Incubate the cells at $37^{\circ} \mathrm{C}$ in a $\mathrm{CO} 2$ incubator for $4-5 \mathrm{~h}$. Add $12 \mathrm{ml}$ of growth medium containing $20 \%$ FBS for a final concentration of $10 \%$ FBS. Incubate cells until $24 \mathrm{~h}$ post-transfection or until they are ready to assay for transgene expression. It is not necessary to remove the complexes or change the medium. Alternatively, growth medium may be replaced after 4-5 $\mathrm{h}$ without loss in transfection activity.

Table 5-10: Transfection of plasmids or siRNAs into cultured cells using lipofectacmine. 


\subsection{Zebrafish}

\subsubsection{Fish breeding and incubation}

Zebrafish were rised and kept uner standard laboratory conditions at a constant lightdark cycle (14 h light/10 h dark (Kimmel et al., 1995; Westerfield, 1995). For breeding, 2 fish were placed in a mating tank, separated by a net over night. In the following morning, the separating net was removed that zebrafish could lay. To avoid parental cannibalism the cage separated parents from eggs. The eggs were collected and transferred to methylene blue egg water or Danieau's solution to prevent the growth of fungi or bacteria. The eggs were maintained at $28.5^{\circ} \mathrm{C}$ until the desired stages. Alternatively, to accelerate or slow down the development, embryos were incubated at $30{ }^{\circ} \mathrm{C}$ or $25^{\circ} \mathrm{C}$, respectively.

Morphological features were used to determine the stage of the embryo according to Kimmel at al.,1995. To dechorionate embros enzymatically, 0.5-1 mg Pronase E was added $/ 1 \mathrm{ml}$ of Danieau's and following dechorionation washed 7 times with Danieau's. When fish older than $24 \mathrm{hpf}$ were used, $0.005 \%$ phenylthiourea (PTU) was added to the Danieaus to prevent melanisation.

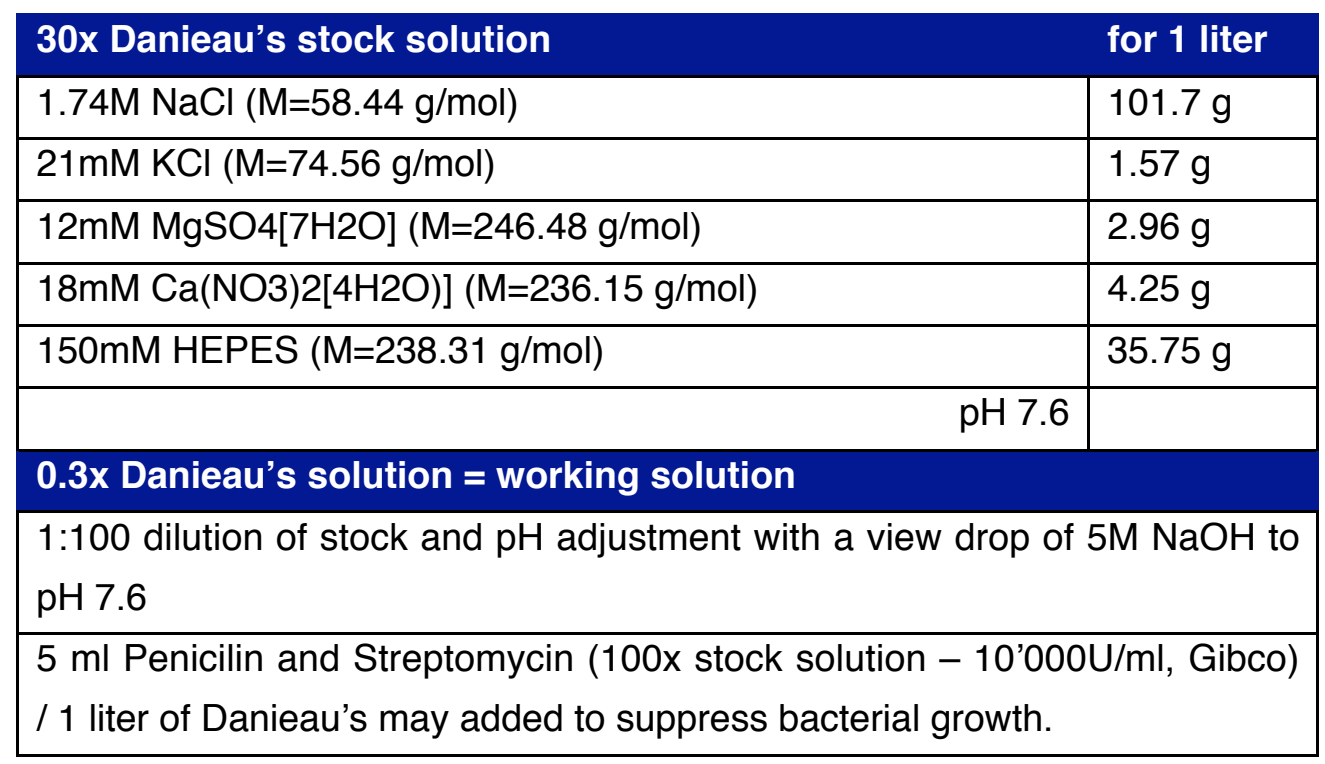




\subsubsection{Morpholinos}

Morpholinos are ribonucleoside analogs with high degradation stability, good RNAbinding affinity and morpholino antisense oligonucleotides are used for efficient expression-inhibition of a specific protein. The dead end morpholino (dnd MO, 5'GCTGGGCATCCATGTCTCCGACCAT-3') and standard control MO were obtained from Genetools (Philomath, OR, USA). Morpholino stock solutions were dissolved in water, $1 \mathrm{mM}$ HEPES pH7.4 or Danieau's buffer. Fresh working dilutions were generated with 10mM HEPES pH7.4 buffer immediately before the experiments.

\subsubsection{Linearization of Plasmid for in vitro transcription}

5-10 $\mu \mathrm{g}$ plasmid DNA was linearized by incubating with 2-4 $\mu \mathrm{l}$ restriction enzyme at 37 ${ }^{\circ} \mathrm{C}$ for 4 hours, purified with PCR Purification Kit (Qiagen), and eluted in $30 \mu \mathrm{H}$ H2O. 1 $\mu l$ elution was loaded on an agarose gel to check the linearization efficiency.

\subsection{4 mRNA Synthesis for Injection}

Synthesis of 7-methyl-guanosine capped sense mRNA for injections was produced according to the standard protocol of mMESSAGE mMACHINE Kit (Ambion) (see in table below)

1. $1 \mu \mathrm{l}$ 10x Reaction buffer, $5 \mu \mathrm{l} 2 \mathrm{x}$ Nucleotide Mix / Cap analog, 50-500ng linearized DNA template, $0.8 \mu \mathrm{l} \mathrm{T3,} \mathrm{T7} \mathrm{or} \mathrm{SP6} \mathrm{Enzyme} \mathrm{Mix,} \mathrm{H} 2 \mathrm{O}$ to a final volume of $10 \mu \mathrm{l}$ were mixed and incubated for $2 \mathrm{~h}$ at $37^{\circ} \mathrm{C}$.

2. To degrade DNA, $0,5 \mu \mathrm{l}$ DNAsel were added and incubate for $20 \mathrm{~min}$ at $37^{\circ} \mathrm{C}$.

\section{Phenol-Chloroform extraction}

3. Add $260 \mu$ l DEPC water

\footnotetext{
4. Add $30 \mu \mathrm{l}$ Ammonium Acetate Stop Solution (Message Machine Kit) and mix

5. Add $300 \mu \mathrm{l} \mathrm{PCl}$ (= Phenol-Chloroform-Isoamylalcohol, 25: 24 : 1, „for RNA“, $\mathrm{pH}=6,6$, from Ambion)

6. Shake vigorously (or vortex) 10 seconds; spin 15 minutes at RT; carefully transfer upper phase to a new tube. Do not take interphase - discard lower phase.

7. Add Cl (= Chloroform-Isoamylalcohol, 24:1), shake vigorously, spin 7 minutes, transfer supernatant to new tube.
}

8. repeat $\mathrm{Cl}$ step once. 


\section{Precipitation and Analysis}

9. Add equal volume of $100 \%$ Isopropanol (room temp.). Do not incubate at $-20^{\circ} \mathrm{C}$ as recommended by the Ambion kit.

10. Centrifuge immediately, 40 minutes. Don't precool the centrifuge, cool down to $4^{\circ} \mathrm{C}$ while spinning.

11. Carefully remove the supernatant using a pipette.

12. Wash $2 x$ with $80 \%$ EtOH (RT)

13. After second wash, remove large drops using a pipette; air dry for a minimum time

14. Dissolve in $20 \mu \mathrm{l} \mathrm{HEPES} \mathrm{(10mM,} \mathrm{pH} \mathrm{7,4,} \mathrm{DEPC} \mathrm{water).} \mathrm{Pipette} \mathrm{up} \mathrm{and} \mathrm{down} \mathrm{to}$ dissolve.

The amount and the quality of the obtained RNAs were estimated by gel electrophoresis and measurements of the UV absorption at _260/280nm.

Table 5-11: Synthesis of sense mRNA for injection of zebrafish embryos.

\subsubsection{Injection of Zebrafish Embryos}

mRNA was diluted with HEPES $(10 \mathrm{mM}, \mathrm{pH} 7,4$, DEPC water) at different concentration. After fertilized zebrafish eggs were collected, aligned in a $1.5 \%$ agarose ramp, about $5 \mathrm{nl}$ RNA solution was injected into each yolk of the embryo. Post-microinjection embryos were kept at $28.5^{\circ} \mathrm{C}$ in Danieau's medium and were checked several hours later to remove the unfertilized and dead eggs.

\subsubsection{Immunostaining of Zebrafish Embryos}

Immunostaining of zebrafish embryos was performed as described below in Table 5-12.

1. Embryos were fixed in PFA $4 \%$ for $2 \mathrm{~h}$ at $4{ }^{\circ} \mathrm{C}$ and $2 \mathrm{~h}$ at $\mathrm{RT}$

2. Wash PBTB (PBS pH 7.4, 0.1\% Tween-20, 0.2\% Triton X-100, 1\% BSA) for $3 \mathrm{~h}$ at RT on shaker.

3. Primary antibody: rabbit-anti vasa (1:1500; P2), anti-HA (1:200; P4) dissolved in PBTB o/n at $4{ }^{\circ} \mathrm{C}$.

4. Wash PBTX (PBS pH 7.4, 0.1\% Tween-20, 0.2\% Triton X-100) for 7h at RT on shaker, in total 12 changes 
5. Secondary antibody: goat-anti-mouse 546 (1:200; orange; S9) and goat-antirabbit Cy2 conjugated (1:200; green; S11) in PBTB overnight at $4{ }^{\circ} \mathrm{C}$

6. Wash PBTX for $7 \mathrm{~h}$ at RT on shaker, in total 12 changes

7. Store at $4{ }^{\circ} \mathrm{C}$ for microscopy.

Table 5-12: Immunostaining of zebrafish embryos.

\subsubsection{DIG- and Fluo- Labeled RNA Probe Synthesis}

DIG- and Fluo- labeled antisense RNA probes were synthesized by incuabting $1 \mu \mathrm{g}-$ 100ng linearized DNA, $4 \mu \mathrm{I} 5 \times$ Transcription Buffer (Fermentas), $2 \mu \mathrm{I}$ DIG-/FluoLabeling Mixture (Roche), $1 \mu$ l RNAse inhibitor, $2 \mu$ SP6, T3 or T7 RNA Polymerase (Fermentas, Roche) in a total volume of $20 \mu \mathrm{l}$ at $37^{\circ} \mathrm{C}$ for 2-2.5 hours and kept dark when Fluorescein (Fluo-) was used. To degrade DNA, 0,5 $\mu \mathrm{l}$ DNAsel (Fermentas) were added and incubate for $20 \mathrm{~min}$ at $37^{\circ} \mathrm{C}$.

For RNA probe precipitation, $11 \mu \mathrm{l} \mathrm{NH}_{4} \mathrm{Ac} 7,8 \mathrm{M}(=1 / 2 \mathrm{Vol})$ and $63 \mu \mathrm{l}$ ethanol $100 \% \mathrm{RT}$ $(=3 \mathrm{Vol})$ were added, mixed and let precipitate for $30-50$ minutes at RT. Following, precipitate were collected by spinning $30-40$ minutes at maximum speed at $20^{\circ} \mathrm{C}$ and washed once with $1 \mathrm{ml}$ ethanol $80 \%$ RT. Air dried pellet was dissolved in $20 \mu \mathrm{l} \mathrm{H}_{2} \mathrm{O}$ and $80 \mu \mathrm{l} \mathrm{Hyb-buffer} \mathrm{(see} \mathrm{below).}$

Alternative to RNA probe precipitation, the transcription product was supplemented with $30 \mu \mathrm{l} \mathrm{H}_{2} \mathrm{O}$, purified with a G-50 Sephadex Micro Columns according to manufactures instruction and $80 \mu \mathrm{l} \mathrm{Hyb}$-buffer added to the elut. $3 \mu \mathrm{l}$ purified probe was checked on an agarose gel.

\subsubsection{Zebrafish One- and Two-Colour Whole Mount In Situ Hybridization}

Zebrafish embryos were fixed in $4 \%$ PFA/PBS at $4{ }^{\circ} \mathrm{C}$ overnight, embryos younger than 2 somite stage were fixed for 2 days. Fish were twice washed with PBS $8 \mathrm{~g} / \mathrm{l}$ $\mathrm{NaCl}, 0.2 \mathrm{~g} / \mathrm{KCl}, 1.8 \mathrm{~g} \mathrm{Na}_{2} \mathrm{HPO}_{4}{ }^{*} 2 \mathrm{H}_{2} \mathrm{O}, 0.24 \mathrm{~g} \mathrm{KH}_{2} \mathrm{PO}_{4}, \mathrm{pH}$ 7,2 ) or PBT (PBS, $0.1 \%$ Tween 20), dechorionated after fixation until the 16-somite stage. Later stages were dechorionated prior to fixation, using forceps and up to 50 embryos per $1.5 \mathrm{ml}$ tube were subjected to whole-mount in situ hybridization (Table 5-13). 


\begin{tabular}{|c|c|c|c|}
\hline & Treatment and Solution & $\mathbf{T}$ & Duration \\
\hline Dehydration & 1. $5 x$ methanol $100 \%$ & RT & 5 minutes \\
\hline \multicolumn{4}{|c|}{ The embryos in $100 \%$ methanol can be stored in $-20{ }^{\circ} \mathrm{C}$ for several months. } \\
\hline \multirow{10}{*}{ 1. Day } & 1. $75 \%$ methanol/PBT, shaking. & RT & 5 minutes \\
\hline & 2. 50\% methanol/PBS, shaking. & RT & 5 minutes \\
\hline & 3. $25 \%$ methanol/PBT, shaking. & RT & 5 minutes \\
\hline & 4. Wash 4x PBT & RT & 5 minutes each \\
\hline & $\begin{array}{l}\text { 5. Digest with } 5 \mu \mathrm{g} / \mathrm{ml} \text { Proteinase } \mathrm{K} \\
\text { (1:1000 dilution from stock in PBT). }\end{array}$ & $\mathrm{RT}$ & $\begin{array}{l}<\text { bud : no } \\
1 \text { somite : } 30 \mathrm{sec} \\
5 \text { somite : } 1-3 \mathrm{~min} \\
24 \mathrm{hpf}: 3-5 \mathrm{~min}\end{array}$ \\
\hline & 6. Wash 3x PBT & RT & 1 minutes each \\
\hline & 7. Refixation with $4 \%$ PFA in PBS & RT & 20 minutes \\
\hline & 8. Wash 5x PBT & RT & 5 minutes each \\
\hline & $\begin{array}{l}\text { 9. Prehybridize in prewarmed } \mathrm{Hyb} \\
\text { buffer }(50 \% \text { formamide, } 5 \times \mathrm{SSC} \text {, } \\
9 \mathrm{mM} \text { Citric acid monohydrate to } \mathrm{pH} \\
6.0-6.5,0.1 \% \text { Tween } 20,500 \mu \mathrm{g} / \mathrm{ml} \\
\mathrm{PCl} \text { extracted Torula yeast tRNA } \\
(\mathrm{SIGMA}), 50 \mu \mathrm{g} / \mathrm{ml} \text { heparin), } \\
\text { incubated in a waterbath. [ } 20 \times \mathrm{SSC} \text {; } \\
3 \mathrm{M} \mathrm{NaCl}, 0.3 \mathrm{M} \mathrm{Na}_{3} \text { Citrat] }\end{array}$ & $67^{\circ} \mathrm{C}$ & $2-5$ hours \\
\hline & $\begin{array}{l}\text { 10. Dilute 1:200 to 5:200 Dig or Fluo } \\
\text { labeled RNA probe into Hyb-buffer. } \\
\text { Hybridize with } 200 \mu \mathrm{l} \mathrm{Hyb-buffer} \mathrm{per} \\
1.5 \mathrm{ml} \text { tube of this solution }\end{array}$ & $67^{\circ} \mathrm{C}$ & Overnight \\
\hline \multirow{5}{*}{ 2. Day } & 1. Wash with Hyb buffer & $67^{\circ} \mathrm{C}$ & $20 \mathrm{~min}$ \\
\hline & $\begin{array}{l}\text { 2. Wash } 3 x \text { with } 50 \% \text { SSCT } 2 x / 50 \% \\
\text { Formamide }\end{array}$ & $67^{\circ} \mathrm{C}$ & $20 \mathrm{~min}$ \\
\hline & $\begin{array}{l}\text { 3. Wash } 1 \times \text { with } 75 \% \text { SSCT } 2 x / 25 \% \\
\text { Formamide }\end{array}$ & $67^{\circ} \mathrm{C}$ & $20 \min$ \\
\hline & 4. Wash $2 x$ with SSCT $2 x$ & $67^{\circ} \mathrm{C}$ & $20 \min$ \\
\hline & 5. Wash $4 x$ with SSCT $0.2 x$ & $67^{\circ} \mathrm{C}$ & $30 \mathrm{~min}$ \\
\hline
\end{tabular}




\begin{tabular}{|c|c|c|c|}
\hline & 6. Wash $1 x$ with PBT & $67^{\circ} \mathrm{C}$ & $5 \min$ \\
\hline & $\begin{array}{l}\text { 7. Blocking with Blocking solution } \\
(5 \% \text { sheep serum and } 10 \mathrm{mg} / \mathrm{ml} \\
\text { BSA in PBT) }\end{array}$ & RT & 1 to several hours \\
\hline & $\begin{array}{l}\text { 8. Antibody Incubation } 1 \text { with } 200 \mu \mathrm{l} \\
\text { preabsorbed Antibody solution: } \\
1: 2000 \text { Anti-Dig or anti-Fluo (Roche), } \\
2 \% \text { sheep serum and } 2 \mathrm{mg} / \mathrm{ml} \mathrm{BSA} \\
\text { in PBT }\end{array}$ & $4{ }^{\circ} \mathrm{C}$ & Overnight \\
\hline \multirow[t]{5}{*}{ 3. Day } & $\begin{array}{l}\text { 1. Wash } 3 x \text { with PBT; keep dark, if } \\
\text { anti-Fluo antibody is used }\end{array}$ & RT & 5 minutes \\
\hline & 2. Wash $8 x$ with $P B T$ & RT & Within 3 hours \\
\hline & $\begin{array}{l}\text { 3. Wash 3x with NTMT (100 mM Tris } \\
\mathrm{HCl} \mathrm{pH} \mathrm{9.5,} 50 \mathrm{mM} \mathrm{MgCl}, 100 \mathrm{mM} \\
\mathrm{NaCl}, 0.3 \% \text { Tween 20) for } 20 \mathrm{ml} \text { use: } \\
2 \mathrm{ml} \text { Tris } \mathrm{HCl} \mathrm{pH} \mathrm{9.5,} 1 \mathrm{M} / 1 \mathrm{ml} \mathrm{MgCl}_{2} \text {, } \\
1 \mathrm{M} / 2 \mathrm{ml} \mathrm{NaCl}, 1 \mathrm{M} / 600 \mu \mathrm{l} \text { Tween } \\
20,10 \% / 14.8 \mathrm{ml} \mathrm{H}_{2} \mathrm{O}\end{array}$ & RT & 5 minutes each \\
\hline & $\begin{array}{l}\text { 4. Transfer embryo into a } 24 \text { well } \\
\text { plate, using a cut } 1 \mathrm{ml} \text { pipet tip }\end{array}$ & & \\
\hline & $\begin{array}{l}\text { 5. Staining (blue): remove most } \\
\text { NTMT and add } 0.5 \mathrm{ml} \text { staining } \\
\text { solution ( } 1 \mathrm{ml} \text { NTMT, } 4.5 \mu \mathrm{l} \text { NBT - } \\
\text { Nitro Blue Tetrazolium, Sigma } \\
\text { N6876, } 75 \mathrm{mg} / \mathrm{ml} \text { in } 70 \% \mathrm{DMF} / 30 \% \\
\mathrm{H} 2 \mathrm{O} \text { ), } 3.5 \mu \mathrm{l} \text { X-phosphate (=BCIP, } \\
50 \mathrm{mg} / \mathrm{ml} \text { in } 100 \% \text { DMF) to each } \\
\text { well. }\end{array}$ & $37^{\circ} \mathrm{C}$ & Various \\
\hline
\end{tabular}




\begin{tabular}{|c|c|c|c|c|}
\hline & $\begin{array}{l}\text { 6. Stop reaction by removing } \\
\text { staining solution and wash } 2 x \text { with } \\
\text { PBT and (only for one colour in situ } \\
\text { hybridization experiment) } 3 x \text { with } \\
\text { Stop solution (1mM EDTA, } 0.1 \% \\
\text { Tween, } 0.05 \mathrm{M} \text { phosphate buffer } \mathrm{pH} \\
5.8 \text { [for } 200 \mathrm{ml} \text { : } 92 \mathrm{ml} 0.1 \mathrm{M} \\
\mathrm{NaH} 2 \mathrm{PO} 4,8 \mathrm{ml} 0.1 \mathrm{M} \mathrm{Na2HPO} 4- \\
\text { this mixture produce a pH of } 5.8] \text { ) }\end{array}$ & $\mathrm{RT}$ & 5 min each \\
\hline \multirow{4}{*}{ 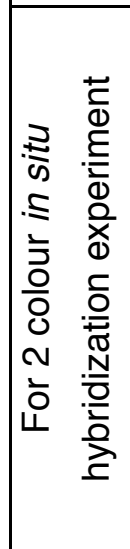 } & \multirow{4}{*}{ 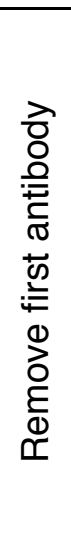 } & \multicolumn{3}{|c|}{$\begin{array}{l}\text { If a two colour in situ hybridization experiment with both, Dig- and } \\
\text { Fluo- labeled antisense probe will be performed, the first antibody has } \\
\text { to be inactivated previous incubation of the embryos with the second } \\
\text { antibody. }\end{array}$} \\
\hline & & \multicolumn{3}{|l|}{ 1. transfer embryos to $1.5 \mathrm{ml}$ tubes } \\
\hline & & $\begin{array}{l}\text { 2. Wash } 2 x \text { embryos in } 0,1 \mathrm{M} \text { Glycin } \\
/ \mathrm{HCl} \mathrm{pH} 2.2 \text { and } 0.1 \% \text { Tween. } \\
\text { Shake well! }\end{array}$ & RT & 5 minutes each \\
\hline & & 3. Wash $4 \mathrm{x}$ with $\mathrm{PBT}$ & RT & 5 minutes each \\
\hline \multirow{7}{*}{\multicolumn{2}{|c|}{ Clearing }} & \multicolumn{3}{|c|}{$\begin{array}{l}\text { If the yolk turned brownish during the staining procedure with NBT/X- } \\
\text { phosphate, washing with ethanol gives clear these staining and } \\
\text { intensify the staining if the embryo. After a few days of storage this } \\
\text { brown precipitate would turn into a black, stable precipitate that } \\
\text { cannot be dissolved away. Therefore, this ethanol treatment has to } \\
\text { be done soon after the completion of the staining reaction. This step } \\
\text { cannot be performed after the red staining reaction. (The red stain } \\
\text { dissolves in ethanol very fast). }\end{array}$} \\
\hline & & 1. Wash $3 x$ with ethanol $100 \%$ & RT & $\begin{array}{l}5 \text { minutes, } \\
2 \times 10 \text { minutes }\end{array}$ \\
\hline & & 2. Wash $75 \%$ ethanol/PBT & $\mathrm{RT}$ & 5 minutes \\
\hline & & 2. Wash $50 \%$ ethanol/PBT & $\mathrm{RT}$ & 5 minutes \\
\hline & & 2. Wash $25 \%$ ethanol/PBT & RT & 5 minutes \\
\hline & & 4. Wash 4x PBT & RT & 5 minutes \\
\hline & & $\begin{array}{l}5 A \text {. For storage: wash } 3 x \text { with Stop } \\
\text { solution }\end{array}$ & RT & 5 minutes \\
\hline
\end{tabular}




\begin{tabular}{|c|c|c|c|}
\hline & $\begin{array}{l}\text { 5B. For second color staining: } \\
\text { Antibody Incubation } 2 \text { with } 200 \mu l \\
\text { preabsorbed Antibody solution: } \\
1: 2000 \text { Anti-Dig or anti-Fluo (Roche), } \\
2 \% \text { sheep serum and } 2 \mathrm{mg} / \mathrm{ml} \mathrm{BSA} \\
\text { in PBT }\end{array}$ & $4^{\circ} \mathrm{C}$ & Overnight \\
\hline \multirow{6}{*}{ 4. Day } & 1. Wash $3 x$ with PBT; keep dark & RT & 5 minutes \\
\hline & 2. Wash $8 x$ with PBT & RT & Within 3 hours \\
\hline & 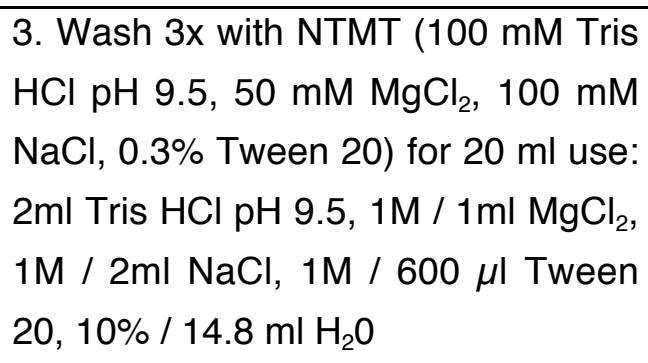 & RT & 5 minutes each \\
\hline & $\begin{array}{l}\text { 4. Transfer embryo into a } 24 \text { well } \\
\text { plate, using a cut } 1 \mathrm{ml} \text { pipet tip }\end{array}$ & & \\
\hline & $\begin{array}{l}\text { 5. Staining (blue): remove most } \\
\text { NTMT and add } 0.5 \mathrm{ml} \text { staining } \\
\text { solution ( } 1 \mathrm{ml} \text { NTMT, } 3.5 \mu \mathrm{l} \text { INT; } 4- \\
\text { lodonitrotetrazolium violet, Sigma, } \\
50 \mathrm{mg} / \mathrm{ml} \text { in DMSO), } 3.5 \mu \mathrm{l} \text { X- } \\
\text { phosphate (=BCIP, } 50 \mathrm{mg} / \mathrm{ml} \mathrm{in} \\
100 \% \text { DMF) to each well. }\end{array}$ & $37^{\circ} \mathrm{C}$ & Various \\
\hline & $\begin{array}{l}\text { 6. Stop reaction by removing } \\
\text { staining solution and wash } 2 \mathrm{x} \text { with } \\
\text { PBT and } 3 \mathrm{x} \text { with Stop solution }(1 \mathrm{mM} \\
\text { EDTA, } 0.1 \% \text { Tween, } 0.05 \mathrm{M} \\
\text { phosphate buffer pH } 5.8 \text { [for } 200 \mathrm{ml} \text { : } \\
92 \mathrm{ml} 0.1 \mathrm{M} \mathrm{NaH2PO} 4,8 \mathrm{ml} 0.1 \mathrm{M} \\
\mathrm{Na} 2 \mathrm{HPO} 4 \text { - this mixture produce a } \\
\text { pH of } 5.8 \text { ]) }\end{array}$ & RT & 5 min each \\
\hline
\end{tabular}

Table 5-13: Whole-mount in situ hybridization of zebrafish embryos. 
The preparation of the yeast torula RNA for the Hyb buffer was done as described in Table 5-14.

1. $500 \mathrm{mg}$ torula yeast total RNA (Sigma) were dissolved in $25 \mathrm{ml}$ (in $50 \mathrm{ml}$ falcon tube) water by vortexing for $30 \mathrm{~min}$

\section{Phenol-Chloroform extraction}

2. Add $25 \mathrm{ml} \mathrm{PCl} \mathrm{(=} \mathrm{Phenol-Chloroform-Isoamylalcohol,} \mathrm{25:} 24$ : 1, „for RNA“, $\mathrm{pH}=6,6$, from Ambion)

3. Vortex $1 \mathrm{~min}$; spin 30 minutes $(6500 \mathrm{rpm})$ at $4^{\circ} \mathrm{C}$; carefully transfer upper phase to a new tube. Do not take interphase - discard lower phase.

7. Add $20 \mathrm{ml} \mathrm{Cl}$ (= Chloroform-Isoamylalcohol, 24:1), vortex, spin 20 minutes (6500 rpm) at $4^{\circ} \mathrm{C}$, transfer supernatant to new tube.

8. repeat $\mathrm{Cl}$ step once.

\section{Precipitation and Analysis}

9. Add equal volume of $100 \%$ Isopropanol (room temp.). Do not incubate at $-20^{\circ} \mathrm{C}$ as recommended.

10. Centrifuge immediately, 1.4 hours at $4^{\circ} \mathrm{C}$.

11. Carefully remove the supernatant using a pipette.

12. Wash $2 x$ with $80 \%$ EtOH (RT)

13. After second wash, remove large drops using a pipette; air dry (can take 2 hours)

14. Dissolve in $5 \mathrm{ml} 20 x$ SSC. Pipette up and down to dissolve and store at $-20^{\circ} \mathrm{C}$

Table 5-14: Synthesis of sense mRNA for injection of zebrafish embryos.

The pre-absobtion of anti-Dig- and anti-Fluo-antibody (Roche) was done as described below.

1. A total volume of 300-500 $\mu$ l zebrafish embryos is harvested in various stages, fixed in $4 \%$ PFA, transferred in methanol and 1. Day of in situ hybridization protocol without prehybridization and hybridization was done as described in above.

2. Embryos are transferred in a $15 \mathrm{ml}$ Falcon tube, $5 \mathrm{ml}$ blocking solution $(2 \mathrm{mg} / \mathrm{ml}$ BSA, $2 \%$ sheep serum, PBT), $25 \mu \mathrm{l}$ anti-Dig- and anti-Fluo-antibody (1:200) were added and with agitation incubated overnight at $4^{\circ} \mathrm{C}$.

3. Optional, to rescue antibody within the embryos, transfer embryos into a $1.5 \mathrm{ml}$ tube 
and dissociate them with a pistil, add $0.5 \mathrm{ml}$ clear antibody solution to the tube and filter this suspension with a $0.2 \mu \mathrm{m}$ syringe filter.

4. $45 \mathrm{ml}$ blocking solution is added to the $5 \mathrm{ml}$ clear antibody solution (1:2000) and supplemented with $100 \mu \mathrm{l}$ of a $10 \% \mathrm{NaN}_{3}$ solution (end-concentration: $0.02 \%$ ).

\subsubsection{Microscopy and Time-Lapse Analysis}

Bright field and fluorescence pictures were made with a Zeiss Axioplan 2 microscope or a Leica confocal DMRXE microscope.

For the time lapse analysis embryos were oriented in agarose ramps overlaid with $0.3 \mathrm{x}$ Danieau's solution. Time-lapse movies were generated using Metamorph software (Universal Imaging) controlling a Zeiss Axioplan2 microscope.

\subsection{Chicken}

\subsubsection{Cultivation of Chicken Embryos}

Fertilized eggs were incubated at $38{ }^{\circ} \mathrm{C}$ in a humid with rolling during the whole incubation time.

\subsubsection{Early Chick (EC)-culture}

Early chick (EC)-culture (Chapman et al., 2001) is a simple method of chick wholeembryo culture, which uses a filter paper carrier to hold the early blastoderm and vitelline membranes under tension while the embryo grows on a substratum of agaralbumen (Table $X-x$ ). This is a quick and efficient means of setting up cultures of chick embryos beginning at pre-primitive streak stages to stage 10.

Preparation of Agar-Albumen Culture Dishes:

1. Heat a water bath to $49^{\circ} \mathrm{C}$.

2. Add $120 \mathrm{ml}$ saline $(7.19 \mathrm{~g} \mathrm{NaCl} / 1$ I distilled water, autoclaved) to a sterile $500 \mathrm{ml}$ flask and bring it to boiling, using a hot plate/stirrer. Add $0.72 \mathrm{~g}$ Bacto-Agar (Difco) and stir until it is dissolved.

3. While the agar is dissolving, collect $120 \mathrm{ml}$ of thin albumen (collected from 2 
dozen unincubated eggs) in sterile Falcon tube $(50 \mathrm{ml})$ or similar container. Place the tubes into the water bath at $49^{\circ} \mathrm{C}$.

4. Once the agar is dissolved, put the flask into the water bath. Allow the liquid to equilibrate at $49^{\circ} \mathrm{C}$.

5. On a flat surface, lay out 80 35-mm sterile Petri dishes with their lids removed.

6 . Add the albumen to the flask containing the dissolved agar, and mix by swirling for 30-60 sec. Also add the penicillin/streptomycin (Sigma, P0906) to this mixture, 5 $\mathrm{U} / \mathrm{ml}$.

7. Using a sterile $10 \mathrm{ml}$ pipette and pipette-aid (e.g., Drummond, Bibby Jet) or similar device, aliquot $2.5 \mathrm{ml}$ of the mixture per Petri dish. Do this reasonably quickly, without introducing bubbles into the dishes. If more than $2.5 \mathrm{ml}$ agar-albumen mixture is pipetted, the substrate will be too thick, subsequently impractical for the imaging of embryos with transillumination.

8. Once the aliquoting is complete, replace the lids of the Petri dishes and leave the dishes for several hours or overnight at room temperature to dry. Place dishes upright in an airtight container at $4^{\circ} \mathrm{C}$ and use them as required. The dishes can be stored at $4^{\circ} \mathrm{C}$ for $1-2$ weeks, provided that sterile conditions are maintained.

Table 5-15: Preparation of Agar-Albumen EC-culture dishes. 

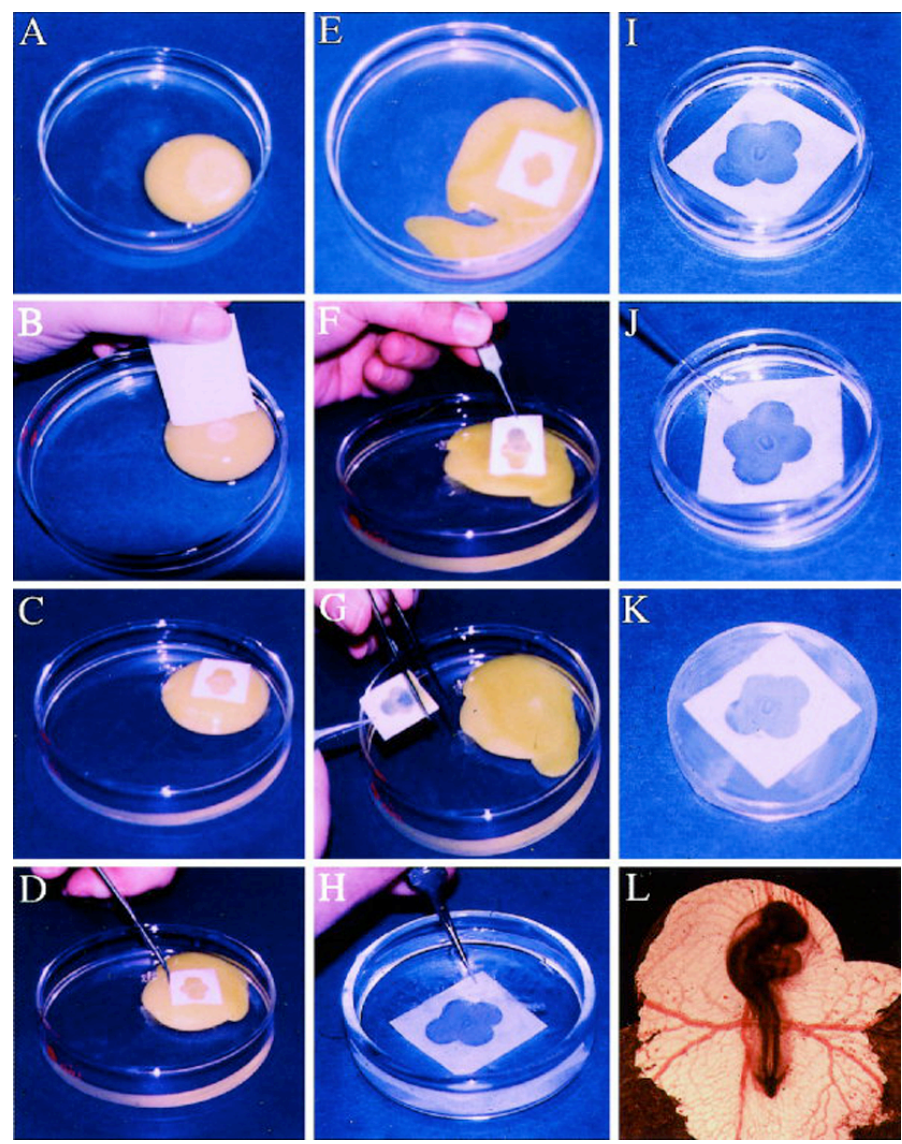

Figure 5-1: Preparation of EC-culture. (Adapted from (Chapman et al., 2001)).

The preparation of the embryo EC-culture was than performed as described below in Table 5-16.

A: Eggs should be incubated on their side until the desired stage ( $\mathrm{HH} 4$ to $\mathrm{HH} 10)$ is reached. After cooling for 15-30 min, break each egg into a glass Petri dish.

B: Using a piece of tissue paper (e.g., Kimwipe) neatly folded, place the tissue paper on the thick albumen and pull the thick albumen away from the blastoderm in a centrifugal direction.

C: Center the filter paper over the blastoderm. If the craniocaudal axis is apparent, align the filter paper with respect to this axis as desired.

$\mathrm{D}$ : Cut the vitelline membranes around the filter paper, ensuring a complete cut.

$\mathrm{E}$ : The filter paper will remain attached to the vitelline membranes after cutting if the albumen has been properly removed.

F: Pull the filter paper away from the yolk in an oblique direction; that is, usually in 
the direction of yolk flow and/or the craniocaudal axis.

G: Using blunt forceps, wipe excess yolk off the filter paper in a centrifugal direction.

$\mathrm{H}$ : For removing as much of the remaining excess yolk as possible, use a small glass Petri dish, filled with saline and $5 \mathrm{U} / \mathrm{ml}$ Penicillin/Streptomycin, and swirl the EC culture to wash away excess yolk.

I: Place the filter and contained blastoderm onto the substrate and cover the dish with a lid. Incubate dishes in a larger Petri dish containing moistened tissue paper lining the bottom of the dish.

J: As an alternative method of washing away yolk, place the filter paper directly onto an agar-albumen culture dish. Using a Pasteur pipette, wash the yolk off with a jet of saline. After washing, remove excess fluid while tilting the dish.

K: For an alternative culture substrate, construct a Parafilm covered Petri-dish lid, containing a central hole. Fill the lid up to the level of the hole with thin albumen. The culture is placed on top of the Petri dish, over the central hole, ventral-side up.

L: An embryo after $44 \mathrm{hr}$ of EC culture

Table 5-16: Preparation of embryos for EC culture.

\subsubsection{Implantation of Cos 7 cells into Chick Embryos}

Cos 7 cells were co-transfected with either CMV- SDF-1a CMV-GFP or CMV-SDF-1 $\beta$ and CMV-GFP as described in chapter "Cell Transfections with Plasmids". As a control, the same total DNA amount of CMV-GFP was used. 24 hours after transfection, an aggregate of transfected Cos 7 cells was grafted between ectoderm and endoderm into embryonic and extra embryonic tissues at different anteriorposterior position of stage $\mathrm{HH} 4$ or $\mathrm{HH} 10$ chicken embryos. Chicken embryos were cultured in Early-Chick (EC)-whole embryo culture either up to stage $\mathrm{HH} 10$ or $\mathrm{HH} 17$, imaged and analyzed after in situ hybridization.

\subsubsection{Electroporation}

Chick embryos were electroporated by a new methode, developed by Dr. Derek Spieler and based on the methods from (Chapman et al., 2001; Endo et al., 2002). In respect to conventional in-ovo electroporation, the advantage of this method is the 
possibility to electroporate high numbers of young chick embryos (HH4) (Spieler, 2004 $\# 1572$ ). For electroporation, the chamber is filled in both compartments with PBS up to the border of the inner ring. Next, the embryo together with the filter paper is taken out of the EC-culture dish and placed with the ventral side down just above the $2 \mathrm{~mm}^{2}$ platin plate cathode. The area, which is electroporated, is placed directly above the cathode. With a glass injection needle, expression vector solution $(2.5 \mu \mathrm{g} / \mu \mathrm{l}-5 \mu \mathrm{g} / \mu \mathrm{l})$ together with $0.025 \%$ Fastgreen (to visualize injection volume)

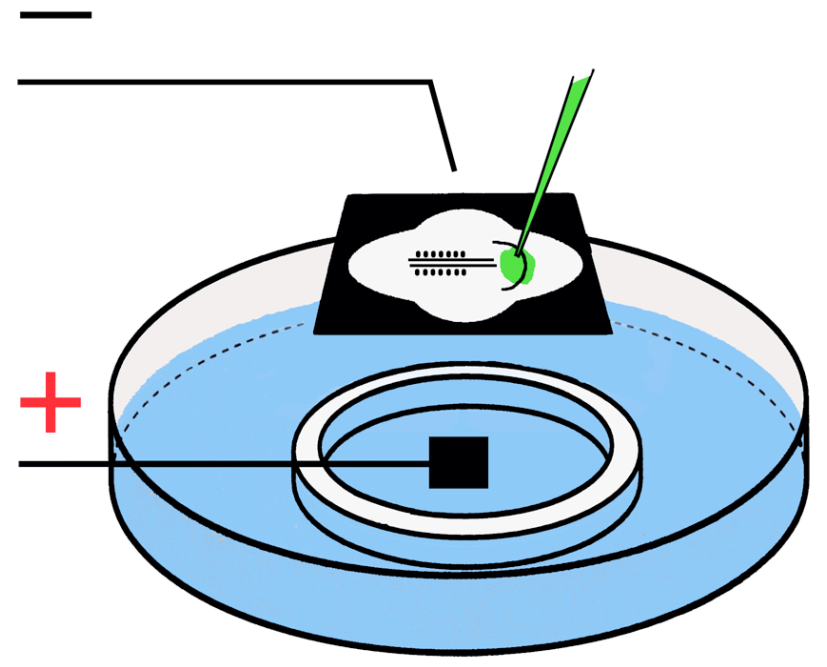

Figure 5-2: Electroporation of embryos in EC culture.

were injected between vitelin membrane and ectoderm. The anode, a platin wire of 0.2 $\mathrm{mm}$ diameter, was than placed carefully onto the embryo and three pulses of 7 volts for 25 milliseconds within 200 milliseconds (using Electro Square Porator ECM 830, Btx Inc.) were applied Finnaly, the embryo was brought back into a EC-culture dish with the dorsal side up and incubated for the appropriate time.

\subsubsection{Chick Whole-Mount In Situ Hybridization}

Chick embryos were fixed in $4 \%$ PFA/PBS at $4{ }^{\circ} \mathrm{C}$ for 4 hours to overnight, and subjected to whole-mount in situ hybridization (Table 5-17).

\begin{tabular}{|c|c|c|c|}
\hline & Treatment and Solution & $\mathrm{T}\left[{ }^{\circ} \mathrm{C}\right]$ & Duration \\
\hline \multirow{3}{*}{ Dehydration } & $\begin{array}{l}\text { 1. Wash the fixed embryos with PBT } \\
3 \text { times, shaking. }\end{array}$ & on ice & 10 min each \\
\hline & 2. $25 \%$ methanol/PBT, shaking. & on ice & $10 \mathrm{~min}$ \\
\hline & 3. 50\% methanol/PBS, shaking. & on ice & $10 \mathrm{~min}$ \\
\hline
\end{tabular}




\begin{tabular}{|c|c|c|c|}
\hline & 4. $75 \%$ methanol/PBT, shaking. & on ice & $10 \mathrm{~min}$ \\
\hline & 5. $100 \%$ methanol, shaking, twice & on ice & 10 min each \\
\hline \multicolumn{4}{|c|}{ The embryos in $100 \%$ methanol can be stored in $-20^{\circ} \mathrm{C}$ up to 2 weeks. } \\
\hline \multirow{14}{*}{ Day 1} & 1. $75 \%$ methanol/PBT, shaking. & on ice & $10 \mathrm{~min}$ \\
\hline & 2. $50 \%$ methanol/PBS, shaking. & on ice & $10 \min$ \\
\hline & 3. $25 \%$ methanol/PBT, shaking. & on ice & $10 \mathrm{~min}$ \\
\hline & 4. Wash with PBT twice, shaking. & on ice & 10 min each \\
\hline & $\begin{array}{l}\text { 5. Bleach with } 6 \% \quad \mathrm{H}_{2} \mathrm{O}_{2} / \mathrm{PBT} \text {, } \\
\text { shaking. }\end{array}$ & on ice & $\begin{array}{l}<\mathrm{HH} 13: 30 \text { min } \\
\mathrm{HH} \mathrm{14-26:} 1 \text { hour }\end{array}$ \\
\hline & 6. Wash with PBT 3 times, shaking. & on ice & 5 min each \\
\hline & $\begin{array}{l}\text { 7. Digest with } 10 \mu \mathrm{g} / \mathrm{ml} \text { Proteinase } \mathrm{K} \\
\text { (1:1000 dilution from stock in PBT). }\end{array}$ & on ice & $\begin{array}{l}<\mathrm{HH} 7: \quad 0.5 \mathrm{~min} \\
\mathrm{HH} 8-10: \quad 1 \mathrm{~min} \\
\mathrm{HH} 11-13: 1.5 \mathrm{~min} \\
\mathrm{HH} 14-16: \quad 5 \mathrm{~min} \\
\mathrm{HH} 17-19: \quad 9 \mathrm{~min} \\
\text { >HH21: } \quad 15 \mathrm{~min}\end{array}$ \\
\hline & $\begin{array}{l}\text { 8. Stop the Proteinase } \mathrm{K} \text { digestion } \\
\text { with about } 2 \mathrm{mg} / \mathrm{ml} \text { glycine in PBT. }\end{array}$ & on ice & $5 \min$ \\
\hline & $\begin{array}{l}\text { 9. Wash with PBT } 3 \text { times. No } \\
\text { agitation }\end{array}$ & on ice & 5-10 min each \\
\hline & $\begin{array}{l}\text { 10. Treat with RIPA buffer (50 mM } \\
\text { Tris, } \mathrm{pH} 8.0,150 \mathrm{mM} \mathrm{NaCl}, 1 \mathrm{mM} \\
\text { EDTA, } 0.1 \% \text { SDS, } 1 \% \mathrm{NP}-40,0.5 \% \\
\text { Sodium deoxycholate) }\end{array}$ & on ice & $\begin{array}{l}<\mathrm{HH} 11: 1 \times 10 \mathrm{~min} \\
\text { 10-16: } 3 \times 10 \mathrm{~min} \\
>\mathrm{HH} 16: 3 \times 20 \mathrm{~min}\end{array}$ \\
\hline & 11. Wash with PBT 3 times & on ice & 5-10 min each \\
\hline & $\begin{array}{l}\text { 12. Refix with } 4 \% \text { PFA, } 0.2 \% \\
\text { glutaraldehyde, and } 0.1 \% \text { Tween } 20 \\
\text { in PBS }\end{array}$ & on ice & $20 \mathrm{~min}$ \\
\hline & 13. Wash with PBT 3 times, shaking. & on ice & 10 min each \\
\hline & $\begin{array}{l}\text { 14. Prehybridize in prewarmed } \\
\text { Prehyb solution ( } 50 \% \text { formamide, } \\
5 \times \mathrm{SSC}, \mathrm{pH} 4.5,1 \% \mathrm{SDS}, 50 \mu \mathrm{g} / \mathrm{ml} \\
\text { yeast tRNA, } 50 \mu \mathrm{g} / \mathrm{ml} \text { heparin), } \\
\text { shaking. [ } 20 \times \mathrm{SSC} ; 3 \mathrm{M} \mathrm{NaCl}, 0.3 \mathrm{M} \\
\mathrm{Na}_{3} \text { Citrat] }\end{array}$ & $67-70^{\circ} \mathrm{C}$ & 4 hours \\
\hline
\end{tabular}




\begin{tabular}{|c|c|c|c|}
\hline & \multicolumn{3}{|c|}{$\begin{array}{l}\text { Or before prehybridization, the embryos can be stored in store mix } \\
(50 \% \text { formamide, } 5 \times \mathrm{SSC}, \mathrm{pH} 4.5) \text { at }-20^{\circ} \mathrm{C} \text { up to months. }\end{array}$} \\
\hline & $\begin{array}{l}\text { 15. Dilute } 1: 100 \text { the DIG labeled } \\
\text { RNA probe (endconcentration: } 1 \\
\mu \mathrm{g} / \mathrm{ml} \text { ) into the Prehyb solution for } \\
\text { hybridization }\end{array}$ & $70^{\circ} \mathrm{C}$ & Overnight \\
\hline \multirow{6}{*}{ Day 2} & $\begin{array}{l}\text { 1. Incubate } \text { with } \\
\text { "Solution1" }(50 \% \text { formarmed } \\
5 \times \text { SSC, } \mathrm{pH} 4.5,1 \% \text { SDS }) \text { twice, } \\
\text { shaking. }\end{array}$ & $70^{\circ} \mathrm{C}$ & 30 min each \\
\hline & $\begin{array}{l}\text { 2. Incubate with prewarmed } \\
\text { "Solution3" }(50 \% \text { formamide, } \\
2 \times \text { SSC, pH } 4.5,0.1 \% \text { Tween } 20) \\
\text { twice, shaking. }\end{array}$ & $70^{\circ} \mathrm{C}$ & 30 min each \\
\hline & $\begin{array}{l}\text { 3. Wash with MABT ( } 100 \mathrm{mM} \text { maleic } \\
\text { acid, } 150 \mathrm{mM} \mathrm{NaCl}, 0.1 \% \text { Tween20, } \\
\mathrm{pH} 7.5) 5 \text { times, shaking. } \\
\text { Flush embryos if necessary to } \\
\text { remove probe from body cavities. }\end{array}$ & RT & 5 min each \\
\hline & $\begin{array}{l}\text { 4. Incubate with } 2 \% \text { Block Reagent } \\
\text { (Roche) in MABT, shaking. }\end{array}$ & RT & $5 \min$ \\
\hline & $\begin{array}{l}\text { 5. Block with blocking solution (2\% } \\
\text { Blocking Reagent Roche, } 20 \% \text { FCS } \\
\text { in MABT), shaking. }\end{array}$ & RT & $2-8$ hours \\
\hline & $\begin{array}{l}\text { 6. Incubate with 1:2000 diluted Anti- } \\
\text { DIG-AP Fab fragment (Roche) in } \\
\text { blocking solution, shaking. }\end{array}$ & $4{ }^{\circ} \mathrm{C}$ & Overnight \\
\hline \multirow[t]{2}{*}{ Day 3-4 } & $\begin{array}{l}\text { 1. Wash with MABT } 6 \text { times. Flush } \\
\text { after three wash steps the embryos if } \\
\text { necessary to remove antibody from } \\
\text { body cavities. }\end{array}$ & RT & 5 min each \\
\hline & $\begin{array}{l}\text { 2. Transfer the embryos into a } \\
\text { sealed } 5 \mathrm{ml} \text { bottle and wash with } \\
\text { MABT for } 48 \text { hours rotating. Refresh } \\
\text { the solution several times. }\end{array}$ & RT & 48 hours \\
\hline
\end{tabular}




\begin{tabular}{|c|c|c|c|}
\hline \multirow{7}{*}{ Day 5} & $\begin{array}{l}\text { 1. Equilibrate embryos with freshly } \\
\text { prepared NTMT/Lev ( } 100 \mathrm{mM} \mathrm{NaCl} \text {, } \\
100 \mathrm{mM} \text { Tris, } \mathrm{pH} 9.5,50 \mathrm{mM} \mathrm{MgCl} \text {, } \\
1 \% \text { Tween20, } 2 \mathrm{mM} \text { Levamisol) } \\
\text { three times, shaking. Levamisol may } \\
\text { is not added to the buffer. }\end{array}$ & $\mathrm{RT}$ & 5 min each \\
\hline & 2. Incubate with NTMT/Lev. & RT & 4 hours \\
\hline & $\begin{array}{l}\text { 3. Stain with } 1: 50 \text { diluted NBT/BCIP } \\
\text { (Roche) in NTMT/Lev in a dark } \\
\text { environment shaking. Control the } \\
\text { staining every } 10 \text { minutes. }\end{array}$ & RT & 10 min-2 hours \\
\hline & $\begin{array}{l}\text { 4. Stop staining reaction by washing } \\
\text { with PBT twice, shaking. }\end{array}$ & $\mathrm{RT}$ & 10 min each \\
\hline & $\begin{array}{l}\text { 5. Incubate with } 50 \% \text { glycerol/PBT, } \\
\text { shaking. }\end{array}$ & RT & $15-60 \mathrm{~min}$ \\
\hline & $\begin{array}{l}\text { 6. Incubate with } 80 \% \text { glycerol/PBT, } \\
\text { shaking. }\end{array}$ & RT & $15-60 \min$ \\
\hline & 7. Take pictures & & \\
\hline
\end{tabular}

Table 5-17: Whole-mount in situ hybridization of chick embryos.

\subsubsection{Histology - Preparation of Paraffin Sections}

Paraffin section after in situ hybridization of chick and mouse embryos was done as described below.

\begin{tabular}{|c|c|c|c|}
\hline & Treatment and Solution & $\mathrm{T}\left[{ }^{\circ} \mathbf{C}\right]$ & Duration \\
\hline $\begin{array}{l}\frac{c}{0} \\
\stackrel{0}{\pi} \\
\stackrel{x}{4}\end{array}$ & $\begin{array}{l}\text { 1. Embryos were fixed or post- } \\
\text { fixed after in situ hybridization in } \\
4 \% \text { PFA }\end{array}$ & $4^{\circ} \mathrm{C}$ & $\begin{array}{l}\text { Overnight to } 24 \\
\text { hours }\end{array}$ \\
\hline 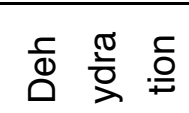 & 2. 2x wash with PBS & RT & $\begin{array}{l}10 \mathrm{~min} \\
\text { each }\end{array}$ \\
\hline
\end{tabular}




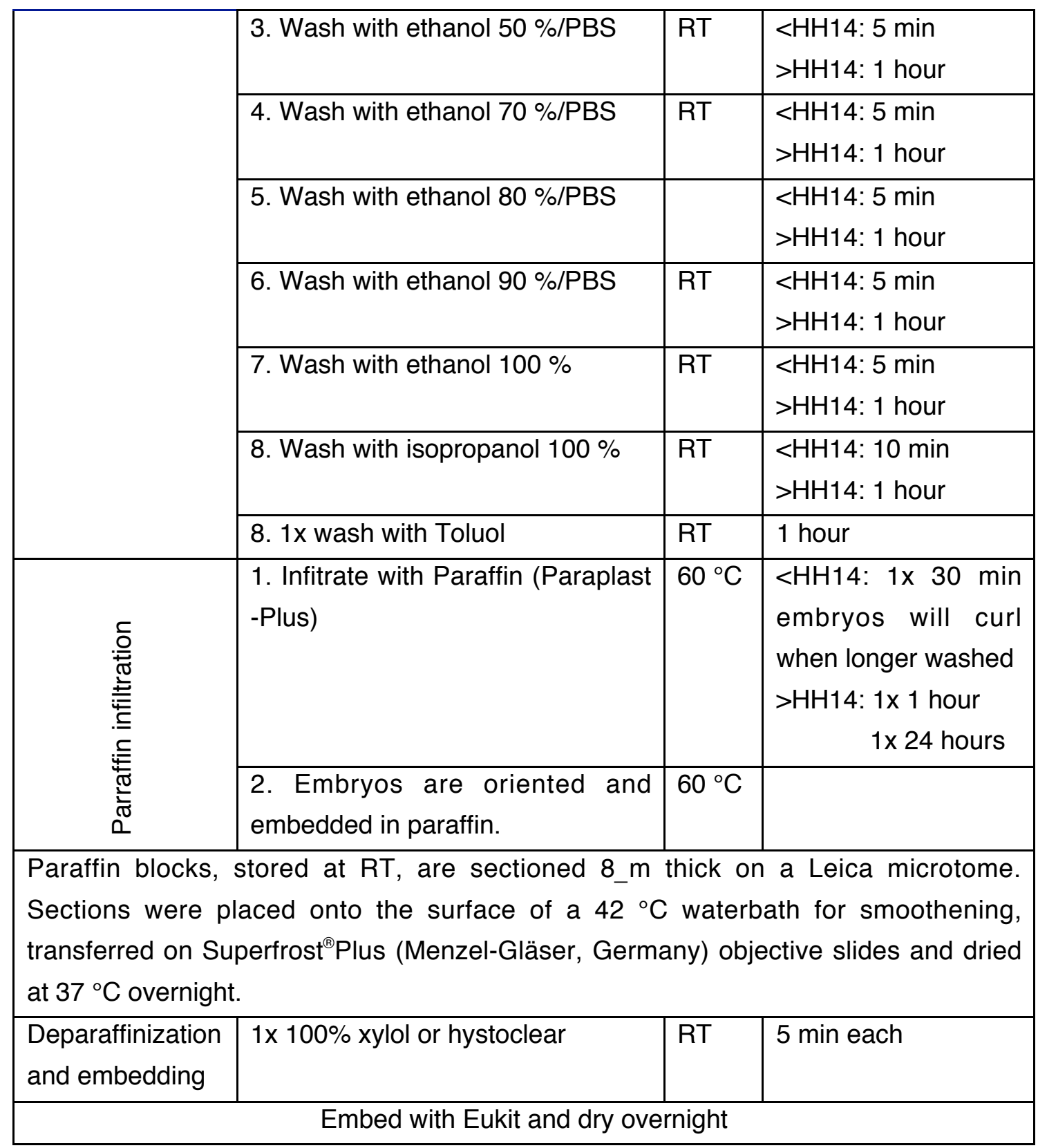

Table 5-18: Preparation of histological paraffin section of chick and mouse embryos.

\subsection{Mouse}

\subsubsection{Mouse Whole-Mount In Situ Hybridization}

Embryos were dissected from the uterus in PBS (cold PBS was used for the stages E9.0-E9.5 and RT warm PBS was used for the stages E10.0-E11.5 that the heart 
keeps contracting and the blood is washed out of the endothelial system) and fixed in $4 \%$ PFA/PBS at $4{ }^{\circ} \mathrm{C}$ for 12 hours to overnight, and subjected to whole-mount in situ hybridization (Table 5-19).

\begin{tabular}{|c|c|c|c|}
\hline & Treatment and Solution & $\mathrm{T}\left[{ }^{\circ} \mathrm{C}\right]$ & Duration \\
\hline \multirow{5}{*}{ Dehydration } & $\begin{array}{l}\text { 1. Wash the fixed embryos with } \\
\text { PBT } 3 \text { times, shaking. }\end{array}$ & on ice & $10 \mathrm{~min}$ each \\
\hline & 2. $25 \%$ methanol/PBT, shaking. & on ice & $10 \min$ \\
\hline & 3. 50\% methanol/PBS, shaking. & on ice & $10 \min$ \\
\hline & 4. $75 \%$ methanol/PBT, shaking. & on ice & $10 \min$ \\
\hline & 5. $100 \%$ methanol, shaking, twice & on ice & 10 min each \\
\hline \multicolumn{4}{|c|}{$\begin{array}{l}\text { In } 100 \% \text { methanol on ice, one hole in the forebrain the hindbrain the heart and the } \\
\text { region of the gonad, all on the same side of the embryo, were done with a tungsten } \\
\text { needle. }\end{array}$} \\
\hline \multicolumn{4}{|c|}{$\begin{array}{l}\text { The embryos are incubated in } 100 \% \text { methanol overnight and may stored for a view } \\
\text { weeks at }-20{ }^{\circ} \mathrm{C} \text {. }\end{array}$} \\
\hline \multirow[t]{9}{*}{ 1. Day } & 1. $75 \%$ methanol/PBT, shaking. & on ice & $10 \min$ \\
\hline & 2. $50 \%$ methanol/PBS, shaking. & on ice & $10 \min$ \\
\hline & 3. $25 \%$ methanol/PBT, shaking. & on ice & $10 \mathrm{~min}$ \\
\hline & 4. Wash with PBT $3 x$, shaking. & on ice & 10 min each \\
\hline & $\begin{array}{l}\text { 5. Bleach with } 6 \% \quad \mathrm{H}_{2} \mathrm{O}_{2} / \mathrm{PBT} \text {, } \\
\text { shaking. }\end{array}$ & on ice & 1 hour \\
\hline & 6. Wash with PBT 3 times, shaking. & RT & 5 min each \\
\hline & $\begin{array}{l}\text { 7. Digest with } 10 \mu \mathrm{g} / \mathrm{ml} \text { Proteinase } \\
\mathrm{K}(1: 1000 \text { dilution from stock in } \\
\text { PBT). } \\
\text { No agitation! }\end{array}$ & RT & $\begin{array}{l}\text { E6.0/6.5: } \quad 2 \mathrm{~min} \\
\text { E7.0/7.5: } \quad 4 \mathrm{~min} \\
\text { E8.0/8.5: } \quad 6 \mathrm{~min} \\
\text { E9.0/9.5: } \quad 8 \mathrm{~min} \\
\text { E10.0/10.5:12min } \\
\text { E11.0/11.5:15min } \\
>E 12.0: \quad 30 \mathrm{~min}\end{array}$ \\
\hline & $\begin{array}{l}\text { 8. Stop the Proteinase } \mathrm{K} \text { digestion } \\
\text { with about } 2 \mathrm{mg} / \mathrm{ml} \text { glycine in PBT. }\end{array}$ & RT & $5 \min$ \\
\hline & $\begin{array}{l}\text { 9. Wash with PBT } 3 \text { times. No } \\
\text { agitation }\end{array}$ & RT & $5-10$ min each \\
\hline
\end{tabular}




\begin{tabular}{|c|c|c|c|}
\hline & $\begin{array}{l}\text { 10. Treat with RIPA buffer ( } 50 \mathrm{mM} \\
\text { Tris, pH } 8.0,150 \mathrm{mM} \mathrm{NaCl}, 1 \mathrm{mM} \\
\text { EDTA, } 0.1 \% \text { SDS, } 1 \% \text { NP- } 40 \text {, } \\
0.5 \% \text { Sodium deoxycholate) }\end{array}$ & RT & 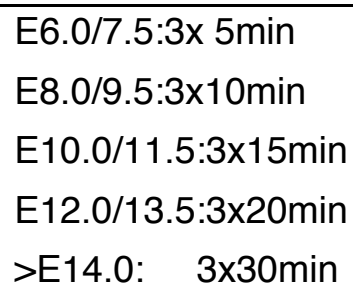 \\
\hline & 11. Wash with PBT 3 times & RT & 5-10 min each \\
\hline & $\begin{array}{l}\text { 12. Refix with } 4 \% \text { PFA, } 0.2 \% \\
\text { glutaraldehyde, and } 0.1 \% \text { Tween } 20 \\
\text { in PBS }\end{array}$ & RT & $20 \min$ \\
\hline & $\begin{array}{l}\text { 13. Wash with PBT } 3 \text { times, } \\
\text { shaking. }\end{array}$ & RT & 10 min each \\
\hline & $\begin{array}{l}\text { 14. Aquilibrate in prewarmed } 50 \% \\
\text { PBT/50\% PBS Prehyb solution } \\
\text { (50\% formamide, } 5 \times \text { SSC, } 9 \mathrm{mM} \\
\text { Citric acid mono-hydrate to } \mathrm{pH} \\
6.0-6.5,0.1 \% \text { Tween } 20,500 \\
\mu \mathrm{g} / \mathrm{ml} \mathrm{PCl} \mathrm{extracted} \mathrm{Torula} \mathrm{yeast} \\
\text { tRNA (SIGMA), } 50 \mu \mathrm{g} / \mathrm{ml} \text { heparin), } \\
\text { shaking. [20x SSC; } 3 \mathrm{M} \mathrm{NaCl,} 0.3 \mathrm{M} \\
\mathrm{Na}_{3} \text { Citrat] }\end{array}$ & $68-70^{\circ}$ & 1 hours \\
\hline & $\begin{array}{l}\text { 15. Prehybridize in prewarmed } \\
\text { Prehyb solution ( } 50 \% \text { formamide, } \\
5 \times \mathrm{SSC}, \quad 9 \mathrm{mM} \text { Citric acid } \\
\text { monohydrate to } \mathrm{pH} 6.0-6.5,0.1 \% \\
\text { Tween } 20,500 \mu \mathrm{g} / \mathrm{ml} \mathrm{PCl} \mathrm{extracted} \\
\text { Torula yeast tRNA (SIGMA), } 50 \\
\mu \mathrm{g} / \mathrm{ml} \text { heparin), shaking. [20x SSC; } \\
3 \mathrm{M} \mathrm{NaCl}, 0.3 \mathrm{M} \mathrm{Na}_{3} \text { Citrat] }\end{array}$ & $68-70{ }^{\circ} \mathrm{C}$ & 1.5-4 hours \\
\hline & $\begin{array}{l}\text { 16. Dilute } 1: 100 \text { the DIG labeled } \\
\text { RNA probe (endconcentration: } 1 \\
\mu \mathrm{g} / \mathrm{ml} \text { ) into the Prehyb solution for } \\
\text { hybridization. }\end{array}$ & $68-70{ }^{\circ} \mathrm{C}$ & Overnight \\
\hline Day 2 & $\begin{array}{l}\text { 1. Wash with Prehyb solution } 2 \\
\text { times, shaking. }\end{array}$ & $68-70{ }^{\circ} \mathrm{C}$ & 30 min each \\
\hline
\end{tabular}




\begin{tabular}{|c|c|c|c|}
\hline & $\begin{array}{l}\text { 2. Wash with } 50 \% \text { Prehyb } \\
\text { solution/50\% RNase-buffer }(500 \\
\mathrm{mM} \mathrm{NaCl,} 10 \mathrm{mM} \text { Tris pH7.5, } 0.1 \\
\% \text { Tween-20), shaking. }\end{array}$ & RT & $5 \mathrm{~min}$ \\
\hline & $\begin{array}{l}\text { 3. RNAseA digestion (RNase- } \\
\text { buffer supplemented with } 100 \\
\mu \mathrm{g} / \mathrm{ml} \text { RNaseA) }\end{array}$ & $37^{\circ} \mathrm{C}$ & $60 \mathrm{~min}$ \\
\hline & $\begin{array}{l}\text { 4. Wash with 50\% RNase-buffer } \\
\text { /50\% "Solution2" (50\% Formamid, } \\
\text { 2x SSC pH7.0, } 0.1 \% \text { Tween-20), } \\
\text { shaking. }\end{array}$ & $68-70{ }^{\circ} \mathrm{C}$ & $5 \mathrm{~min}$ \\
\hline & 5. Wash 10x with "Solution2" & $68-70{ }^{\circ} \mathrm{C}$ & $\begin{array}{l}2 \times 5 \mathrm{~min} \\
3 \times 10 \mathrm{~min} \\
5 \times 30 \mathrm{~min}\end{array}$ \\
\hline & $\begin{array}{l}\text { 6. Wash with } 50 \% \text { "Solution2"/ } 50 \% \\
\text { MABT ((100 mM maleic acid, } 150 \\
\mathrm{mM} \mathrm{NaCl,} \mathrm{0.1 \%} \mathrm{Tween20,} \mathrm{pH} 7.5) \text {. }\end{array}$ & RT & $5 \mathrm{~min}$ \\
\hline & 7. Wash $3 x$ with MABT & RT & 10 min each \\
\hline & $\begin{array}{l}\text { 8. Block with blocking solution (2\% } \\
\text { Blocking Reagent Roche, } 20 \% \\
\text { FCS in MABT), shaking. }\end{array}$ & RT & 6 hours \\
\hline & $\begin{array}{l}\text { 9. Incubate with 1:2000 diluted } \\
\text { Anti-DIG-AP Fab fragment (Roche) } \\
\text { in blocking solution, shaking. }\end{array}$ & $4^{\circ} \mathrm{C}$ & Overnight \\
\hline ח & $\begin{array}{l}\text { 1. Wash } 3 x \text { with blocking solution } \\
\text { with } 5 \% \text { FCS only. }\end{array}$ & RT & In total $4-6$ hours \\
\hline Day & $\begin{array}{l}\text { 2. Wash with MABT. Change 2-3 } \\
\text { times per day MABT. }\end{array}$ & RT & In total 4 days \\
\hline
\end{tabular}




\begin{tabular}{|c|c|c|c|}
\hline \multirow{4}{*}{ Day 6} & 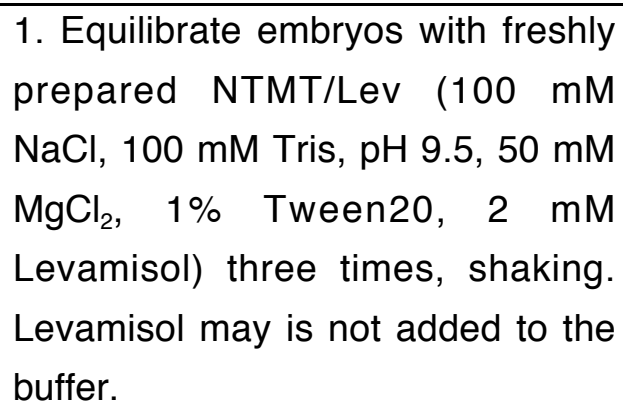 & RT & 20 min each \\
\hline & $\begin{array}{l}\text { 2. Stain with } 1: 50 \text { diluted } \\
\text { NBT/BCIP (Roche) in NTMT/Lev in } \\
\text { a dark environment shaking. } \\
\text { Control the staining every } 10 \\
\text { minutes. }\end{array}$ & RT & 10 min-2 hours \\
\hline & $\begin{array}{l}\text { 3. Stop staining reaction by } \\
\text { washing } 3 x \text { with } \mathrm{PBT} \text {, shaking. }\end{array}$ & RT & 10 min each \\
\hline & 4. Postfixation in $4 \%$ PFA / PBT & $4^{\circ} \mathrm{C}$ & Overnight \\
\hline \multirow{3}{*}{ Day 7-9 } & $\begin{array}{l}\text { 1. Incubate with } 30 \% \text { glycerol/PBT, } \\
\text { shaking. }\end{array}$ & $4^{\circ} \mathrm{C}$ & Overnight \\
\hline & $\begin{array}{l}\text { 2. Incubate with } 50 \% \text { glycerol/PBT, } \\
\text { shaking. }\end{array}$ & $4{ }^{\circ} \mathrm{C}$ & Overnight \\
\hline & $\begin{array}{l}\text { 3. Incubate with } 80 \% \text { glycerol/PBT, } \\
\text { shaking and store at } 4{ }^{\circ} \mathrm{C}\end{array}$ & $44^{\circ} \mathrm{C}$ & Overnight - months \\
\hline
\end{tabular}

Table 5-19: Whole-mount in situ hybridization of mouse embryos.

\subsubsection{Mouse Organ Culture and Time Lapse}

Transverse slices from the hindgut regions of heterozygous Oct4 $\triangle P E$ :GFP transgenic mouse embryos expressing GFP in the germ cell lineage were cultured and filmed as previously described (Molyneaux et al., 2003). Images for time lapse were captured every 7 minutes starting at $\mathrm{E}$ 9.5. This work was done in collaboration with Kathleen Molyneaux at the Cincinnati Children Hospital. 


\section{References}

Abi-Younes, S., Sauty, A., Mach, F., Sukhova, G. K., Libby, P., and Luster, A. D. (2000). The stromal cell-derived factor-1 chemokine is a potent platelet agonist highly expressed in atherosclerotic plaques. Circ Res 86, 131-138.

Aiuti, A., Webb, I., Bleul, C., Springer, T., and Gutierrez-Ramos, J. (1997). The chemokine SDF-1 is a chemoattractant for human CD34+ hematopoietic progenitor cells and provides a new mechanism to explain the mobilization of CD34+ progenitors to peripheral blood. J Exp Med 185, 111-120.

Amara, A., Lorthioir, O., Valenzuela, A., Magerus, A., Thelen, M., Montes, M., Virelizier, J. L., Delepierre, M., Baleux, F., Lortat-Jacob, H., and Arenzana-Seisdedos, F. (1999). Stromal cell-derived factor-1alpha associates with heparan sulfates through the first beta-strand of the chemokine. J Biol Chem 274, 23916-23925.

Anderson, R., Copeland, T. K., Scholer, H., Heasman, J., and Wylie, C. (2000). The onset of germ cell migration in the mouse embryo. Mech Dev 91, 61-68.

Anderson, R., Fassler, R., Georges-Labouesse, E., Hynes, R., Bader, B., Kreidberg, J., Schaible, K., Heasman, J., and Wylie, C. (1999). Mouse primordial germ cells lacking beta1 integrins enter the germline but fail to migrate normally to the gonads. Development 126, 1655-1664.

Ara, T., Nakamura, Y., Egawa, T., Sugiyama, T., Abe, K., Kishimoto, T., Matsui, Y., and Nagasawa, T. (2003). Impaired colonization of the gonads by primordial germ cells in mice lacking a chemokine, stromal cell-derived factor-1 (SDF-1). Proc Natl Acad Sci U S A 100, 5319-5323.

Asada, Y., Varnum, D. S., Frankel, W. N., and Nadeau, J. H. (1994). A mutation in the Ter gene causing increased susceptibility to testicular teratomas maps to mouse chromosome 18. Nat Genet 6, 363-368.

Beck, A. R., Miller, I. J., Anderson, P., and Streuli, M. (1998). RNA-binding protein TIAR is essential for primordial germ cell development. Proc Natl Acad Sci U S A 95, 2331-2336.

Beddington, R. S., and Robertson, E. J. (1999). Axis development and early asymmetry in mammals. Cell 96, 195-209.

Bernex, F., De Sepulveda, P., Kress, C., Elbaz, C., Delouis, C., and Panthier, J. (1996). Spatial and temporal patterns of c-kit-expressing cells in WlacZ/+ and WlacZ/WlacZ mouse embryos. Development 122, 3023-3033. 
Bleul, C., Fuhlbrigge, R., Casasnovas, J., Aiuti, A., and Springer, T. (1996a). A highly efficacious lymphocyte chemoattractant, stromal cell-derived factor 1 (SDF-1). J Exp Med 184, 1101-1109.

Bleul, C. C., Farzan, M., Choe, H., Parolin, C., Clark-Lewis, I., Sodroski, J., and Springer, T. A. (1996b). The lymphocyte chemoattractant SDF-1 is a ligand for LESTR/fusin and blocks HIV-1 entry. Nature 382, 829-833.

Braat, A., Zandbergen, T., van de Water, S., Goos, H., and Zivkovic, D. (1999). Characterization of zebrafish primordial germ cells: morphology and early distribution of vasa RNA. Dev Dyn 216, 153-167.

Buckley, C. D., Amft, N., Bradfield, P. F., Pilling, D., Ross, E., Arenzana-Seisdedos, F., Amara, A., Curnow, S. J., Lord, J. M., Scheel-Toellner, D., and Salmon, M. (2000). Persistent induction of the chemokine receptor CXCR4 by TGF-beta 1 on synovial T cells contributes to their accumulation within the rheumatoid synovium. J Immunol 165, 3423-3429.

Campbell, J. J., Hedrick, J., Zlotnik, A., Siani, M. A., Thompson, D. A., and Butcher, E. C. (1998). Chemokines and the arrest of lymphocytes rolling under flow conditions. Science 279, 381-384.

Chang, H., and Matzuk, M. M. (2001). Smad5 is required for mouse primordial germ cell development. Mech Dev 104, 61-67.

Chapman, S. C., Collignon, J., Schoenwolf, G. C., and Lumsden, A. (2001). Improved method for chick whole-embryo culture using a filter paper carrier. Dev Dyn 220, 284289.

Ciruna, B., Weidinger, G., Knaut, H., Thisse, B., Thisse, C., Raz, E., and Schier, A. F. (2002). Production of maternal-zygotic mutant zebrafish by germ-line replacement. Proc Natl Acad Sci U S A 99, 14919-14924.

Coffman, C. R., Strohm, R. C., Oakley, F. D., Yamada, Y., Przychodzin, D., and Boswell, R. E. (2002). Identification of X-linked genes required for migration and programmed cell death of Drosophila melanogaster germ cells. Genetics 162, 273284.

Crump, M. P., Gong, J. H., Loetscher, P., Rajarathnam, K., Amara, A., ArenzanaSeisdedos, F., Virelizier, J. L., Baggiolini, M., Sykes, B. D., and Clark-Lewis, I. (1997). Solution structure and basis for functional activity of stromal cell-derived factor-1; dissociation of CXCR4 activation from binding and inhibition of HIV-1. EMBO J 16, 6996-7007.

de Sousa Lopes, S. M., Roelen, B. A., Monteiro, R. M., Emmens, R., Lin, H. Y., Li, E., Lawson, K. A., and Mummery, C. L. (2004). BMP signaling mediated by ALK2 in the visceral endoderm is necessary for the generation of primordial germ cells in the mouse embryo. Genes Dev 18, 1838-1849. 
Doitsidou, M., Reichman-Fried, M., Stebler, J., Koprunner, M., Dorries, J., Meyer, D., Esguerra, C. V., Leung, T., and Raz, E. (2002). Guidance of Primordial Germ Cell Migration by the Chemokine SDF-1. Cell 111, 647-659.

Dumstrei, K., Mennecke, R., and Raz, E. (2004). Signaling pathways controlling primordial germ cell migration in zebrafish. J Cell Sci 117, 4787-4795.

Eddy, E. (1975). Germ plasm and the differentiation of the germ cell line. Int Rev Cytol 43, 229-280.

Endo, Y., Osumi, N., and Wakamatsu, Y. (2002). Bimodal functions of Notch-mediated signaling are involved in neural crest formation during avian ectoderm development. Development 129, 863-873.

Epstein, R. J. (2004). The CXCL12-CXCR4 chemotactic pathway as a target of adjuvant breast cancer therapies. Nat Rev Cancer 4, 901-909.

Garcia-Castro, M., Anderson, R., Heasman, J., and Wylie, C. (1997). Interactions between germ cells and extracellular matrix glycoproteins during migration and gonad assembly in the mouse embryo. J Cell Biol 138, 471-480.

Ginsburg, M., and Eyal-Giladi, H. (1987). Primordial germ cells of the young chick blastoderm originate from the central zone of the area pellucida irrespective of the embryo-forming process. Development 101, 209-219.

Ginsburg, M., Snow, M. H. L., and McLaren, A. (1990). Primordial germ cells in the mouse embryo during gastrulation. Development 110, 521-528.

Gleichmann, M., Gillen, C., Czardybon, M., Bosse, F., Greiner-Petter, R., Auer, J., and Muller, H. W. (2000). Cloning and characterization of SDF-1gamma, a novel SDF-1 chemokine transcript with developmentally regulated expression in the nervous system. Eur J Neurosci 12, 1857-1866.

Gomperts, M., Garcia-Castro, M., Wylie, C., and Heasman, J. (1994). Interactions between primordial germ cells play a role in their migration in mouse embryos. Development 120, 135-141.

Grabovsky, V., Feigelson, S., Chen, C., Bleijs, D. A., Peled, A., Cinamon, G., Baleux, F., Arenzana-Seisdedos, F., Lapidot, T., van Kooyk, Y., et al. (2000). Subsecond induction of alpha4 integrin clustering by immobilized chemokines stimulates leukocyte tethering and rolling on endothelial vascular cell adhesion molecule 1 under flow conditions. J Exp Med 192, 495-506.

Hamburger, V., and Hamilton, H. (1951). A series of normal stages in the development of the chick embryo. J Morphol 88, 49-82. 
Hay, B., Jan, L., and Jan, Y. (1988). A protein component of Drosophila polar granules is encoded by vasa and has extensive sequence similarity to ATP-dependent helicases. Cell 55, 577-587.

Hayashi, K., Kobayashi, T., Umino, T., Goitsuka, R., Matsui, Y., and Kitamura, D. (2002). SMAD1 signaling is critical for initial commitment of germ cell lineage from mouse epiblast. Mech Dev 118, 99-109.

Hernandez, P. A., Gorlin, R. J., Lukens, J. N., Taniuchi, S., Bohinjec, J., Francois, F., Klotman, M. E., and Diaz, G. A. (2003). Mutations in the chemokine receptor gene CXCR4 are associated with WHIM syndrome, a combined immunodeficiency disease. Nat Genet 34, 70-74.

Houston, D., and King, M. (2000a). Germ plasm and molecular determinants of germ cell fate. Curr Top Dev Biol 50, 155-181.

Houston, D. W., and King, M. L. (2000b). A critical role for Xdazl, a germ plasmlocalized RNA, in the differentiation of primordial germ cells in Xenopus. Development $127,447-456$.

Houston, D. W., Zhang, J., Maines, J. Z., Wasserman, S. A., and King, M. L. (1998). A Xenopus DAZ-like gene encodes an RNA component of germ plasm and is a functional homologue of Drosophila boule. Development 125, 171-180.

Hudson, C., and Woodland, H. R. (1998). Xpat, a gene expressed specifically in germ plasm and primordial germ cells of Xenopus laevis. Mech Dev 73, 159-168.

Ikenishi, K. (1998). [Formation of primordial germ cells (PGCs) in amphibia]. Tanpakushitsu Kakusan Koso 43, 382-389.

Jaglarz, M., and Howard, K. (1994). Primordial germ cell migration in Drosophila melanogaster is controlled by somatic tissue. Development $120,83-89$.

Jaglarz, M. K., and Howard, K. R. (1995). The active migration of Drosophila primordial germ cells. Development 121, 3495-3503.

Jongens, T. A., Hay, B., Jan, L. Y., and Jan, Y. N. (1992). The germ cell-less gene product: a posteriorly localized component necessary for germ cell development in Drosophila. Cell 70, 569-584.

Kanatsu-Shinohara, M., Inoue, K., Lee, J., Yoshimoto, M., Ogonuki, N., Miki, H., Baba, S., Kato, T., Kazuki, Y., Toyokuni, S., et al. (2004). Generation of pluripotent stem cells from neonatal mouse testis. Cell 119, 1001-1012.

Karagenc, L., Cinnamon, Y., Ginsburg, M., and Petitte, J. N. (1996). Origin of primordial germ cells in the prestreak chick embryo. Dev Genet 19, 290-301. 
Kimmel, C. (1989). Genetics and early development of zebrafish. Trends Genet 5, 283-288.

Kimmel, C., Ballard, W., SR, K., B, U., and TF, S. (1995). Stages of embryonic development of the zebrafish. Dev Dyn 203, 253-310.

Knaut, H., Pelegri, F., Bohmann, K., Schwarz, H., and Nusslein-Volhard, C. (2000). Zebrafish vasa RNA but not its protein is a component of the germ plasm and segregates asymmetrically before germline specification. J Cell Biol 149, 875-888.

Knaut, H., Werz, C., Geisler, R., and Nusslein-Volhard, C. (2003). A zebrafish homologue of the chemokine receptor $\mathrm{Cxcr} 4$ is a germ-cell guidance receptor. Nature $421,279-282$.

Kobayashi, S. (1998). [Mechanism underlying germline formation in Drosophila melanogaster]. Tanpakushitsu Kakusan Koso 43, 356-363.

Kobayashi, S., Yamada, M., Asaoka, M., and Kitamura, T. (1996). Essential role of the posterior morphogen nanos for germline development in Drosophila. Nature 380, 708711.

Koprunner, M., Thisse, C., Thisse, B., and Raz, E. (2001). A zebrafish nanos-related gene is essential for the development of primordial germ cells. Genes Dev 15, 28772885.

Kunwar, P. S., Starz-Gaiano, M., Bainton, R. J., Heberlein, U., and Lehmann, R. (2003). Tre1, a G Protein-Coupled Receptor, Directs Transepithelial Migration of Drosophila Germ Cells. PLoS Biol 1, E80.

Lasko, P., and Ashburner, M. (1988). The product of the Drosophila gene vasa is very similar to eukaryotic initiation factor-4A. Nature 611-617 335, 611-617.

Lawson, K. A., Dunn, N. R., Roelen, B. A., Zeinstra, L. M., Davis, A. M., Wright, C. V., Korving, J. P., and Hogan, B. L. (1999). Bmp4 is required for the generation of primordial germ cells in the mouse embryo. Genes Dev 13, 424-436.

Lehmann, R., and Nusslein-Volhard, C. (1991). The maternal gene nanos has a central role in posterior pattern formation of the Drosophila embryo. Development 112, 679-691.

Ma, Q., Jones, D., Borghesani, P. R., Segal, R. A., Nagasawa, T., Kishimoto, T., Bronson, R. T., and Springer, T. A. (1998). Impaired B-lymphopoiesis, myelopoiesis, and derailed cerebellar neuron migration in CXCR4- and SDF-1-deficient mice. Proc Natl Acad Sci U S A 95, 9448-9453.

Matsui, Y., Zsebo, K., and Hogan, B. (1992). Derivation of pluripotential embryonic stem cells from murine primordial germ cells in culture. Cell 70, 841-847. 
McLaren, A. (1999). Signaling for germ cells. Genes Dev 13, 373-376.

Molyneaux, K., and Wylie, C. (2004). Primordial germ cell migration. Int J Dev Biol 48, 537-544.

Molyneaux, K., Zinszner, H., Kunwar, P., Schaible, K., Stebler, J., Sunshine, M., O'Brien, W., Raz, E., Littman, D., Wylie, C., and Lehmann, R. (2003). The chemokine SDF1/CXCL12 and its receptor CXCR4 regulate mouse germ cell migration and survival. Development 130, 4279-4286.

Molyneaux, K. A., Stallock, J., Schaible, K., and Wylie, C. (2001). Time-lapse analysis of living mouse germ cell migration. Dev Biol 240, 488-498.

Moore, L. A., Broihier, H. T., Van Doren, M., Lunsford, L. B., and Lehmann, R. (1998). Identification of genes controlling germ cell migration and embryonic gonad formation in Drosophila. Development 125, 667-678.

Muller, A., Homey, B., Soto, H., Ge, N., Catron, D., Buchanan, M. E., McClanahan, T., Murphy, E., Yuan, W., Wagner, S. N., et al. (2001). Involvement of chemokine receptors in breast cancer metastasis. Nature 410, 50-56.

Nagasawa, T., Hirota, S., Tachibana, K., Takakura, N., Nishikawa, S., Kitamura, Y., Yoshida, N., Kikutani, H., and Kishimoto, T. (1996). Defects of B-cell lymphopoiesis and bone-marrow myelopoiesis in mice lacking the CXC chemokine PBSF/SDF-1. Nature 382, 635-638.

Nakamura, M., Kuwana, T., Miyayama, Y., and Fujimoto, T. (1988). Extragonadal distribution of primordial germ cells in the early chick embryo. Anat Rec 222, 90-94.

Nasevicius, A., and Ekker, S. C. (2000). Effective targeted gene 'knockdown' in zebrafish. Nat Genet 26, 216-220.

Niewkoop, P. D., and Sutasurya, L. A. (1979). Primordial germ cells in the chordates, In Cambridge University Press, pp. 118-123.

Noce, T., Okamoto-Ito, S., and Tsunekawa, N. (2001). Vasa homolog genes in mammalian germ cell development. Cell Struct Funct 26, 131-136.

Noguchi, T., and Noguchi, M. (1985). A recessive mutation (ter) causing germ cell deficiency and a high incidence of congenital testicular teratomas in 129/Sv-ter mice. J Natl Cancer Inst 75, 385-392.

Ohnishi, Y., Senda, T., Nandhagopal, N., Sugimoto, K., Shioda, T., Nagal, Y., and Mitsui, Y. (2000). Crystal structure of recombinant native SDF-1alpha with additional mutagenesis studies: an attempt at a more comprehensive interpretation of accumulated structure-activity relationship data. J Interferon Cytokine Res 20,691700 . 
Olsen, L. C., Aasland, R., and Fjose, A. (1997). A vasa-like gene in zebrafish identifies putative primordial germ cells. Mech Dev 66, 95-105.

Peled, A., Grabovsky, V., Habler, L., Sandbank, J., Arenzana-Seisdedos, F., Petit, I., Ben-Hur, H., Lapidot, T., and Alon, R. (1999). The chemokine SDF-1 stimulates integrin-mediated arrest of CD34(+) cells on vascular endothelium under shear flow. J Clin Invest 104, 1199-1211.

Pellas, T. C., Ramachandran, B., Duncan, M., Pan, S. S., Marone, M., and Chada, K. (1991). Germ-cell deficient (gcd), an insertional mutation manifested as infertility in transgenic mice. Proc Natl Acad Sci U S A 88, 8787-8791.

Petitte, J. N., Karagenc, L., and Ginsburg, M. (1997). The origin of the avian germ line and transgenesis in birds. Poult Sci 76, 1084-1092.

Phillips, R., and Ager, A. (2002). Activation of pertussis toxin-sensitive CXCL12 (SDF1) receptors mediates transendothelial migration of $T$ lymphocytes across lymph node high endothelial cells. Eur J Immunol 32, 837-847.

Pitt, J., Schisa, J., and Priess, J. (2000). P granules in the germ cells of Caenorhabditis elegans adults are associated with clusters of nuclear pores and contain RNA. Dev Biol 219, 315-333.

Raz, E. (2000). The function and regulation of vasa-like genes in germ-cell development. Genome Biol 1, 1017.1011-1017.1016.

Raz, E. (2003). Primordial germ-cell development: the zebrafish perspective. Nat Rev Genet 4, 690-700.

Raz, E. (2004). Guidance of primordial germ cell migration. Curr Opin Cell Biol 16, 169-173.

Reichman-Fried, M., Minina, S., and Raz, E. (2004). Autonomous modes of behavior in primordial germ cell migration. Dev Cell 6, 589-596.

Rich, T., Watson, C., and Wyllie, A. (1999). Apoptosis: the germs of death. Natur Cell Biology 1, E69-E71.

Rogulska, T. (1969). Migration of the chick primordial germ cells from the intracoelomically transplanted germinal crescent into the genital ridge. Experientia 25, 631-632.

Rogulska, T., Ozdzenski, W., and Komar, A. (1971). Behaviour of mouse primordial germ cells in the chick embryo. J Embryol Exp Morphol 25, 155-164. 
Sadir, R., Baleux, F., Grosdidier, A., Imberty, A., and Lortat-Jacob, H. (2001). Characterization of the stromal cell-derived factor-1alpha-heparin complex. J Biol Chem 276, 8288-8296.

Saitou, M., Barton, S. C., and Surani, M. A. (2002). A molecular programme for the specification of germ cell fate in mice. Nature 418, 293-300.

Santos, A. C., and Lehmann, R. (2004). Germ cell specification and migration in Drosophila and beyond. Curr Biol 14, R578-589.

Seydoux, G., and Schedl, T. (2001). The germline in C. elegans: origins, proliferation, and silencing. Int Rev Cytol 203, 139-185.

Seydoux, G., and Strome, S. (1999). Launching the germline in Caenorhabditis elegans: regulation of gene expression in early germ cells. Development 126, 32753283.

Slanchev, K., Stebler, J., de la Cueva-Mendez, G., and Raz, E. (2005). Development without germ cells: the role of the germ line in zebrafish sex differentiation. Proc Natl Acad Sci U S A 102, 4074-4079.

Staller, P., Sulitkova, J., Lisztwan, J., Moch, H., Oakeley, E. J., and Krek, W. (2003). Chemokine receptor CXCR4 downregulated by von Hippel-Lindau tumour suppressor pVHL. Nature 425, 307-311.

Starz-Gaiano, M. (2002). Molecular Guidance Cues and Intracellular Signaling in Drosophila Germ Cell Migration. Thesis New York Univ.

Starz-Gaiano, M., Cho, N. K., Forbes, A., and Lehmann, R. (2001). Spatially restricted activity of a Drosophila lipid phosphatase guides migrating germ cells. Development 128, 983-991.

Starz-Gaiano, M., and Lehmann, R. (2001). Moving towards the next generation. Mech Dev 105, 5-18.

Stein, J. A., Broihier, H. T., Moore, L. A., and Lehmann, R. (2002). Slow as molasses is required for polarized membrane growth and germ cell migration in Drosophila. Development 129, 3925-3934.

Stevens, L. (1970). The development of transplantable teratocarcinomas from intratesticular grafts of pre-and post-implantation embryos. Dev Biol 21, 364-382.

Stevens, L. C. (1973). A new inbred subline of mice (129-terSv) with a high incidence of spontaneous congenital testicular teratomas. J Natl Cancer Inst 50, 235-242.

Stevens, L. C., and Hummel, K. P. (1957). A description of spontaneous congenital testicular teratomas in strain 129 mice. J Natl Cancer Inst 18, 719-747. 
Stevens, L. C., and Little, C. C. (1954). Spontaneous testicular teratomas in an inbred strain mice. Proc natn Acad Sci USA 40, 1080-1087.

Styhler, S., Nakamura, A., Swan, A., Suter, B., and Lasko, P. (1998). vasa is required for GURKEN accumulation in the oocyte, and is involved in oocyte differentiation and germline cyst development. Development 125, 1569-1578.

Subramaniam, K., and Seydoux, G. (1999). nos-1 and nos-2, two genes related to Drosophila nanos, regulate primordial germ cell development and survival in Caenorhabditis elegans. Development 126, 4861-4871.

Tachibana, K., Hirota, S., lizasa, H., Yoshida, H., Kawabata, K., Kataoka, Y., Kitamura, Y., Matsushima, K., Yoshida, N., Nishikawa, S., et al. (1998). The chemokine receptor CXCR4 is essential for vascularization of the gastrointestinal tract. Nature 393, 591594.

Tam, P., and Zhou, S. (1996). The allocation of epiblast cells to ectodermal and germline lineages is influenced by the position of the cells in the gastrulating mouse embryo. Dev Biol 178, 124-132.

Tanaka, S., Toyooka, Y., Akasu, R., Katoh-Fukui, Y., Nakahara, Y., Suzuki, R., Yokoyama, M., and Noce, T. (2000). The mouse homolog of Drosophila Vasa is required for the development of male germ cells. Genes Dev 14, 841-853.

Tanaka, S. S., and Matsui, Y. (2002). Developmentally regulated expression of mil-1 and mil-2, mouse interferon-induced transmembrane protein like genes, during formation and differentiation of primordial germ cells. Mech Dev 119 Suppl 1, S261267.

Thorpe, J. L., Doitsidou, M., Ho, S. Y., Raz, E., and Farber, S. A. (2004). Germ cell migration in zebrafish is dependent on HMGCoA reductase activity and prenylation. Dev Cell 6, 295-302.

Tomancak, P., Guichet, A., Zavorszky, P., and Ephrussi, A. (1998). Oocyte polarity depends on regulation of gurken by Vasa. Development 125, 1723-1732.

Tremblay, K. D., Dunn, N. R., and Robertson, E. J. (2001). Mouse embryos lacking Smad1 signals display defects in extra-embryonic tissues and germ cell formation. Development 128, 3609-3621.

Tsunekawa, N., Naito, M., Sakai, Y., Nishida, T., and Noce, T. (2000). Isolation of chicken vasa homolog gene and tracing the origin of primordial germ cells. Development 127, 2741-2750.

Vincent, S. D., Dunn, N. R., Sciammas, R., Shapiro-Shalef, M., Davis, M. M., Calame, K., Bikoff, E. K., and Robertson, E. J. (2005). The zinc finger transcriptional repressor 
Blimp1/Prdm1 is dispensable for early axis formation but is required for specification of primordial germ cells in the mouse. Development 132, 1315-1325.

Wang, C., and Lehmann, R. (1991). Nanos is the localized posterior determinant in Drosophila [published erratum appears in Cell 1992 Mar 20;68(6):1177]. Cell 66, 637647.

Weidinger, G., Stebler, J., Slanchev, K., Dumstrei, K., Wise, C., Lovell-Badge, R., Thisse, C., Thisse, B., and Raz, E. (2003). dead end, a novel vertebrate germ plasm component, is required for zebrafish primordial germ cell migration and survival. Curr Biol 13, 1429-1434.

Weidinger, G., Wolke, U., Koprunner, M., Klinger, M., and Raz, E. (1999a). Identification of tissues and patterning events required for distinct steps in early migration of zebrafish primordial germ cells. Development 126, 5295-5307.

Weidinger, G., Wolke, U., Koprunner, M., Klinger, M., and Raz, E. (1999b). Identification of tissues and patterning events required for distinct steps in early migration of zebrafish primordial germ cells. Development 126, 5295-5307.

Weidinger, G., Wolke, U., Koprunner, M., Thisse, C., Thisse, B., and Raz, E. (2002). Regulation of zebrafish primordial germ cell migration by attraction towards an intermediate target. Development 129, 25-36.

Westerfield, M. (1995). The Zebrafish Book (Oregon: University of Oregon Press).

Wolke, U., Weidinger, G., Koprunner, M., and Raz, E. (2002). Multiple levels of posttranscriptional control lead to germ line-specific gene expression in the zebrafish. Curr Biol 12, 289-294.

Wylie, C. (1999). Germ cells. Cell 96, 165-174.

Wylie, C. (2000). Germ cells. Curr Opin Genet Dev 10, 410-413.

Xu, E. Y., Moore, F. L., and Pera, R. A. (2001). A gene family required for human germ cell development evolved from an ancient meiotic gene conserved in metazoans. Proc Natl Acad Sci U S A 98, 7414-7419.

Ying, Y., Liu, X. M., Marble, A., Lawson, K. A., and Zhao, G. Q. (2000). Requirement of $\mathrm{Bmp8b}$ for the generation of primordial germ cells in the mouse. Mol Endocrinol 14, 1053-1063.

Ying, Y., Qi, X., and Zhao, G. Q. (2001). Induction of primordial germ cells from murine epiblasts by synergistic action of BMP4 and BMP8B signaling pathways. Proc Natl Acad Sci U S A 98, 7858-7862. 
Ying, Y., and Zhao, G. Q. (2001). Cooperation of endoderm-derived BMP2 and extraembryonic ectoderm- derived BMP4 in primordial germ cell generation in the mouse. Dev Biol 232, 484-492.

Yoon, C., Kawakami, K., and Hopkins, N. (1997). Zebrafish vasa homologue RNA is localized to the cleavage planes of 2- and 4-cell-stage embryos and is expressed in the primordial germ cells. Development 124, 3157-3165.

Youngren, K. K., Coveney, D., Peng, X., Bhattacharya, C., Schmidt, L. S., Nickerson, M. L., Lamb, B. T., Deng, J. M., Behringer, R. R., Capel, B., et al. (2005). The Ter mutation in the dead end gene causes germ cell loss and testicular germ cell tumours. Nature 435, 360-364.

Zeelenberg, I. S., Ruuls-Van Stalle, L., and Roos, E. (2003). The chemokine receptor CXCR4 is required for outgrowth of colon carcinoma micrometastases. Cancer Res 63, 3833-3839.

Zhang, N., Zhang, J., Purcell, K. J., Cheng, Y., and Howard, K. (1997). The Drosophila protein Wunen repels migrating germ cells. Nature 385, 64-67.

Zhao, G. Q., and Garbers, D. L. (2002). Male germ cell specification and differentiation. Dev Cell 2, 537-547.

Zhu, Y., Yu, T., Zhang, X. C., Nagasawa, T., Wu, J. Y., and Rao, Y. (2002). Role of the chemokine SDF-1 as the meningeal attractant for embryonic cerebellar neurons. Nat Neurosci 5, 719-720. 


\section{Acknowledgments}

I would specially like to thank Erez Raz for his guidance and directional advices during this work, which resulted in an eminent student-scientist transdifferentiation process that will help me on my future way.

I thank Prof. Gerhard Braus and Prof. Tomas Pieler for their help, discussions and support during my thesis.

I would also like to thank all former and present members of the Raz lab for the atmosphere they created; especially Krasimir for the nice team work, the Swiss crew of Heiko and Markus for bringing a little bit of charming home into the lab, Michal for her open and critical suggestions to the work and manuscripts, Karin as the calm and supportive pole and Sonia alias Pumuckl, Natalia, Maria and Elena for creating every day interesting.

At this point, I would also like to express my gratitude to Michael Kessel for his enormous support and advices, the discussions and of course the cake sessions. I would like to thank Derek and Lars for the nice collaborations and introducing me into the world of classical embryology and Lingfei for all the fun during working hours.

I am very grateful to Julia, Wiebke and Helene for the never-ending support "in good times and in times of crash, stress and emergency".

Many thanks go to Steffen Burckhardt and to the team of the Molecular Biology Program, who did a great job and created an excellent platform for my scientific education and development.

I would also like to thank Sandro Brandenberger, Mevio Heierli, Christoph Peter alias Simpson and the "WG-family" for being there when I need them, providing me over the last years with continuous power that I needed for my work and making Switzerland to my home.

Last but not least, I would like to thank my family, my parents Heidi and Alois for their support and love, Monika and Christian for still liking me and Regina to be and stay with me. 


\section{Appendix}

\subsection{Affidavit}

Here I declare that my thesis entitled "Germ Cell Development and Migration" has been done independently and with no other sources and aids than quoted and listed below.

Figure 2-6 D-I: Time lapse analysis of migrating mouse PGCs in a section through the gonad was done in collaboration with Kathleen Molyneaux.

Figure 2-7: $\quad$ The human and mouse dead end homologues were cloned by Gilbert Weidinger.

Figure 2-12 A-C:The Xenopus in situ hybridization was done by Gilbert Weidinger, the mouse in situ hybridization was done by Clare Wise and Robin LovellBadge.

Jürg Stebler

August $27^{\text {th }}, 2005$

Göttingen 


\subsection{List of Publications}

Vasyutina E., Stebler J., Brand-Saberi B., Raz E., and Birchmeier C., CXCR4 and Gab1 co-operate to control the development of migrating muscle progenitor cells. Submitted for publication.

Slanchev. K., Stebler. J., de la Cueva-Méndez. G., and Raz. E.. Development without germ cells: the role of the germline in zebrafish sex differentiation. PNAS. 2005 Feb 23.

Stebler J., Spieler D, Slanchev K., Molyneaux K.A., Richter U., Cojocaru V., Tarabykin V., Wylie C., Kessel M., Raz E. (2004). Primordial germ cell migration in the chick and mouse embryo: the role of the chemokine SDF-1/CXCL12. Developmental Biololy $15 ; 272(2): 351-61$

Spieler, D., Baumer, N., Stebler, J., Koprunner, M., Reichman-Fried, M., Teichmann, U., Raz, E., Kessel, M. and Wittler, L. (2004) Involvement of Pax6 and Otx2 in the forebrain-specific regulation of the vertebrate homeobox gene ANF/Hesx1. Developmental Biology 269: 567-579.

Molyneaux, K.A., Zinszner, H., Kunwar, P.S., Schaible, K., Stebler, J., Sunshine, M.J., O'Brien, W., Raz , E., Littman, D., Wylie, C. and Lehmann, R. (2003) The chemokine SDF1/CXCL12 and its receptor CXCR4 regulate mouse germ cell migration and survival. Development 130: 4279-4286.

Weidinger, G., Stebler, J., Slanchev, K., Dumstrei, K., Wise, C., Lovell-Badge, R., Thisse, C., Thisse, B. and Raz, E. (2003) dead end, a Novel Vertebrate Germ Plasm Component, Is Required for Zebrafish Primordial Germ Cell Migration and Survival. Current Biology 13:1429-1434.

Doitsidou, M., Reichman-Fried, M., Stebler, J., Köprunner, M., Dörries, J., Meyer, D., Esguerra, V.C., Leung, T. and Raz, E. (2002) Guidance of primordial germ cell migration by the chemokine SDF-1. Cell 111: 647-659. 


\subsection{Curriculum Vitae}

PERSONAL INFORMATION

Name: $\quad$ Jürg Stebler

Citizen: $\quad$ Switzerland

Date of Birth: $\quad$ 10.02.1977

Marital status: $\quad$ single

Place of birth: Zurich

SCIENTIFIC EDUCATION

2002- Dissertation, Germ Cell Development, Max Planck Institute for Biophysical present Chemistry, Germany

Graduation with A. Master-PhD Program Molecular Biology, Int. Max

2001 Planck Research School and University of Göttingen, Germany

1999 University of Applied Science, Winterthur, Switzerland

1996 assistant Ciba-Geigy AG Basel, Switzerland 